\title{
Annual Site Environmental Report For Calendar Year 2001
}
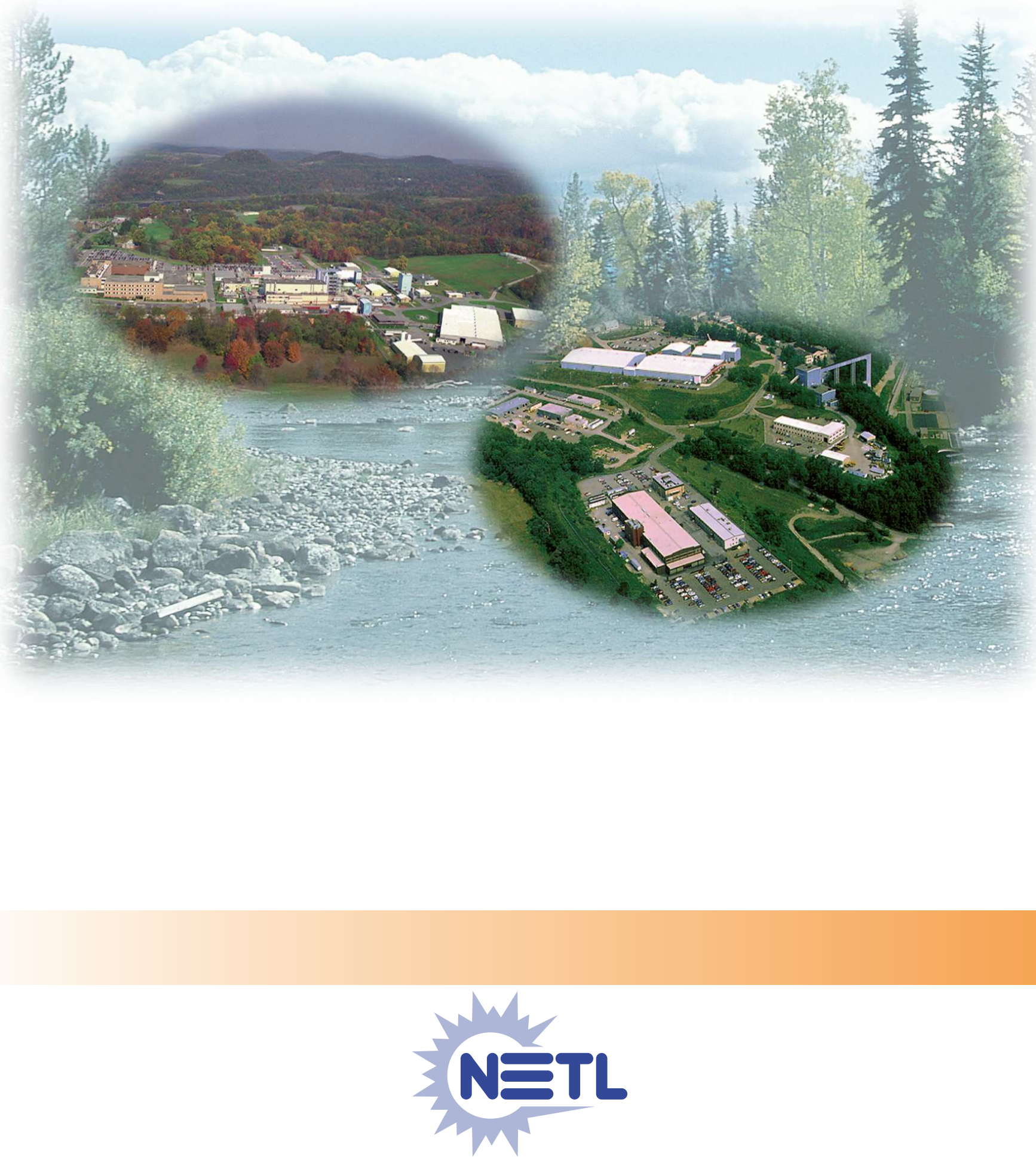
DOE/NETL-2002/1180

\section{The National Energy Technology Laboratory Annual Site Environmental Report for Calendar Year 2001}

October 2002

U.S. Department of Energy

National Energy Technology Laboratory

Morgantown, West Virginia

Pittsburgh, Pennsylvania

Tulsa, Oklahoma

Fairbanks, Alaska

NETL Customer Service Line: (800) 553-7681

NETL Homepage: www.netl.doe.gov 


\section{Disclaimer}

Reference herein to any specific commercial product, process, or service by trade name, trademark, manufacturer, or otherwise does not necessarily constitute or imply its endorsement, recommendation, or favoring by the United State Government or any agency thereof. The views and opinions of authors expressed herein do not necessarily state or reflect those of the United States Government or any agency thereof.

Available to DOE employees and contractors from the Office of Scientific and Technical Information, P.O. Box 62, 175 Oak Ridge

Turnpike, Oak Ridge, TN 37831; prices are available by phone: (423) 576-8401; fax: (423) 576-5725; or e-mail: reports@ adonis.osti.gov.

Available to the public from the National Technical Information Service, U.S. Department of Commerce, 5285 Port Royal Road, Springfield, VA 22161; phone orders accepted at (703) 487-4650. 


\section{Preface}

This Site Environmental Report was prepared by the Environmental, Safety, and Health Division at the National Energy Technology Laboratory (NETL) for the U.S. Department of Energy. The purpose of this report is to inform the public and Department of Energy stakeholders of the environmental conditions at the NETL sites in Morgantown, West Virginia, Pittsburgh, Pennsylvania, Tulsa, Oklahoma, and Fairbanks. This report contains the most accurate information that could be collected during the period between January 1, 2001, through December 31, 2001. As stated in DOE Orders 5400.1 and 231.1, the purpose of the report is to:

- $\quad$ Characterize site environmental management performance.

- $\quad$ Confirm compliance with environmental standards and requirements.

- $\quad$ Highlight significant facility programs and efforts.

A reader questionnaire/comment form is included on the following page to provide an opportunity for public input on current and future site environmental reports.

\section{Office of Fossil Energy}

\section{Commitment to Environment, Safety and Health}

Fossil Energy is committed to conducting our mission to achieve the greatest benefit for all our stakeholders, including our employees and the public, while actively adhering to the highest standards for environment, safety, and health. Fossil Energy will continuously improve our practices through effective integration of environment, safety, and health into all facets of work planning and execution. Fossil Energy will make consistent, measurable progress in implementing this commitment throughout our operations while striving for zero injuries, incidents, and environmental releases. 


\section{Questionnaire National Energy Technology Laboratory 2001 Site Environmental Report}

Please answer the following questions and return to:

Elias George

National Energy Technology Laboratory - Pittsburgh

P.O. Box 10940

Pittsburgh, PA 15236

If you are viewing the electronic version, you can email your response to elias.george@netl.doe.gov

1. Was the 2001 Site Environmental Report easy to read and understand? If not, please provide a brief explanation.

2. Was the information contained in the report useful? Please provide a brief explanation.

3. Do you feel the report contained all of the information that you would be interested in? If not, please provide a brief explanation.

4. Do you have any comments or suggestions on how the current and future reports can be improved?

5. Other comments or suggestions? 


\section{Contents}

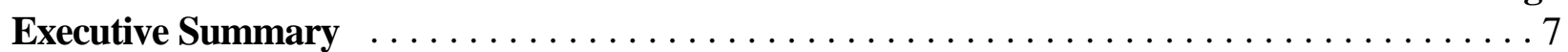

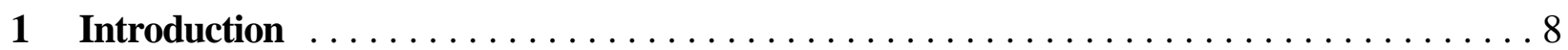

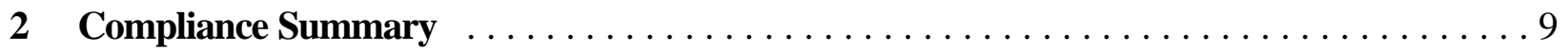

2.1 Comprehensive Environmental Response, Compensation, and Liability Act . . . . . 10

2.2 Superfund Amendment and Reauthorization Act $\ldots \ldots \ldots \ldots \ldots \ldots \ldots \ldots$

$2.3 \quad$ Clean Air Act . . . . . . . . . . . . . . . . . . . . . . . . . . . . . . . 14

2.4 Clean Water Act and the National Pollutant Discharge Elimination System . . . . . . 16

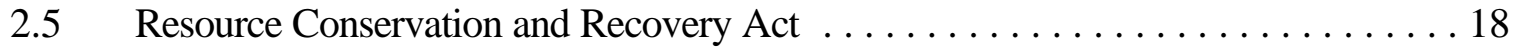

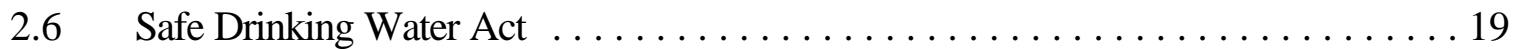

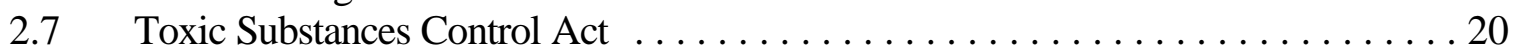

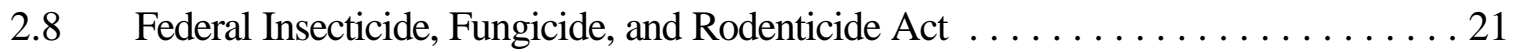

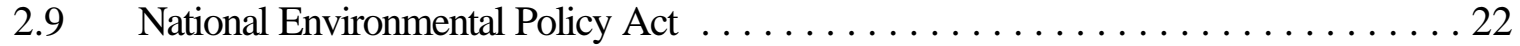

2.10 Federal Facility Compliance Act . . . . . . . . . . . . . . . . . 23

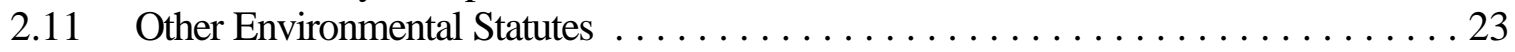

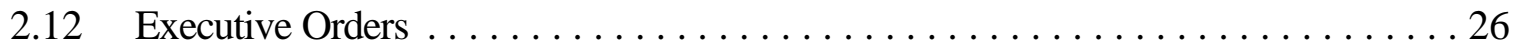

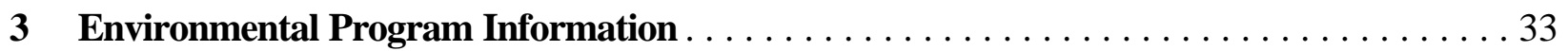

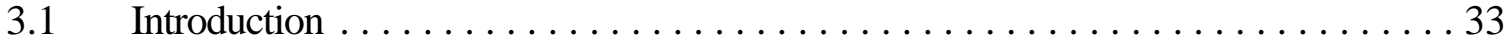

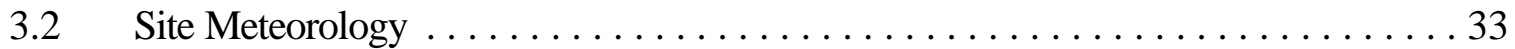

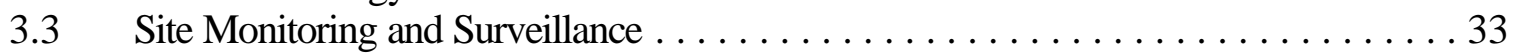

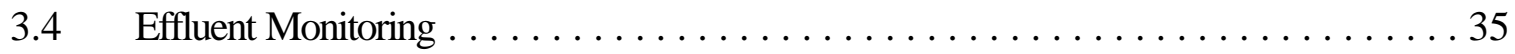

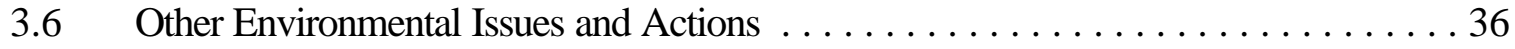

4 Environmental Management Information $\ldots \ldots \ldots \ldots \ldots \ldots \ldots \ldots \ldots \ldots \ldots \ldots \ldots$

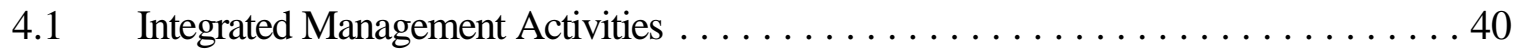

5 Environmental Radiological Program Information $\ldots \ldots \ldots \ldots \ldots \ldots \ldots \ldots \ldots \ldots$

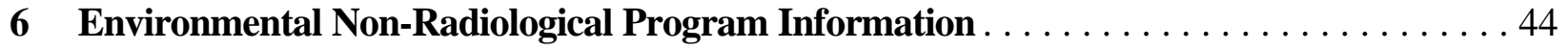

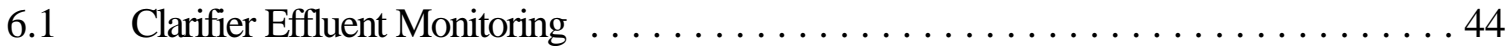

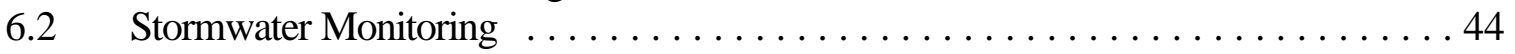

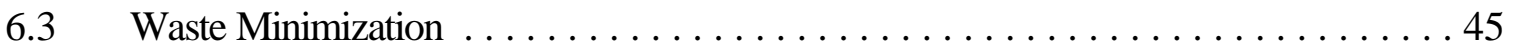

7 Site Hydrology, Groundwater Monitoring and Public Drinking Water Protection . . . . . 47

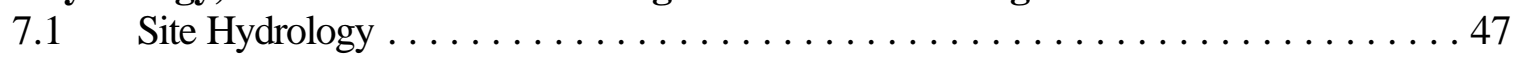

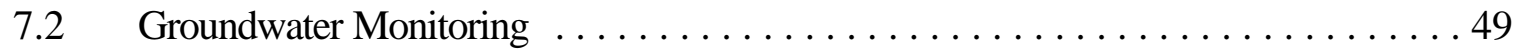

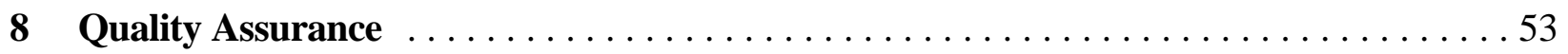




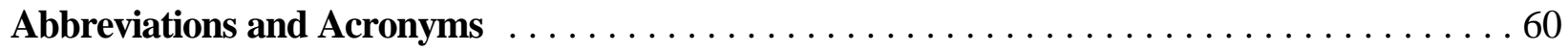

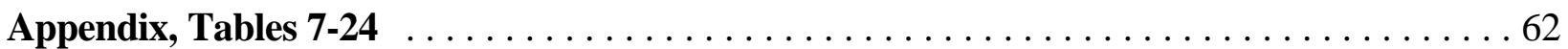

\section{List of Tables}

Table

Page

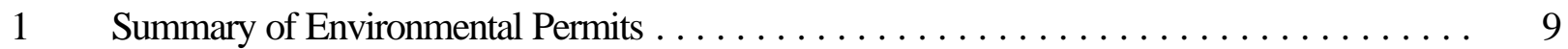

2 Emergency Planning and Community Right-to-Know Act Reporting . . . . . . . . . . 13

3 Sara Title III, Tier II Chemical Inventory Reporting List $\ldots \ldots \ldots \ldots \ldots \ldots \ldots \ldots$

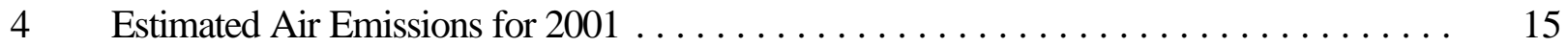

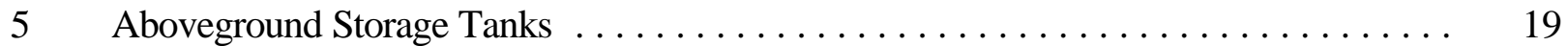

$6 \quad$ NETL Radioactive Materials Inventory for $2001 \ldots \ldots \ldots \ldots \ldots \ldots \ldots \ldots$. . . . . . . . 42

7 NETL 2001 National Pollutant Discharge Elimination System Storm Water Analysis Results 62

8 NETL-PGH 2001 Wastewater Effluent Analysis . . . . . . . . . . . . . . . 63

9 NETL-PGH Industrial Sewer Use Permit Monitoring Analysis . . . . . . . . . . . . . . . 65

10 NETL-PGH 2001 Groundwater Detection Monitoring Program, Results of Analysis Groundwater Samples, Main Plateau - Contamination Indicator Constituents . . . . . . 66

11 NETL-PGH 2001 Groundwater Detection Monitoring Program, Results of Analysis Groundwater Samples, Valley Fill - Contamination Indicator Constituents . . . . . . . . . 68

12 NETL-PGH 2001 Groundwater Detection Monitoring Program, Results of Analysis Groundwater Samples, Main Plateau - Groundwater Characteristics Constituents . . . . 70

13 NETL-PGH 2001 Groundwater Detection Monitoring Program, Results of Analysis Groundwater Samples, Valley Fill - Groundwater Characteristics Constituents . . . . . . 72

14 NETL-PGH 2001 Groundwater Detection Monitoring Program, Results of Analysis Groundwater Samples, Main Plateau - Semivolatile Organic Compounds Constituents . 74

15 NETL-PGH 2001 Groundwater Detection Monitoring Program, Results of Analysis Groundwater Samples, Valley Fill - Semivolatile Organic Compounds Constituents . . . . 76

16 NETL-PGH 2001 Groundwater Detection Monitoring Program, Results of Analysis Groundwater Samples, Valley Fill - TPH Constituents . . . . . . . . . . . . 78

17 NETL-PGH 2001 Groundwater Detection Monitoring Program, Results of Analysis Groundwater Samples, Main Plateau - Volatile Organic Compounds Constituents . . . . . 79

18 NETL-PGH 2001 Groundwater Detection Monitoring Program, Results of Analysis Groundwater Samples, Valley Fill - Volatile Organic Compounds Constituents . . . . . . 81

19 NETL-MGN April 2001 Groundwater Data for "Morgantown Aquifer," . . . . . . . . . 82

20 NETL-MGN April 2001 Groundwater Data for "A Aquifer," . . . . . . . . . . . . . 83

21 NETL-MGN April 2001 Groundwater Data for "B-C Aquifer," . . . . . . . . . . . . . 84

22 NETL-MGN August 2001 Groundwater Data for "Morgantown Aquifer" . . . . . . . . 85

23 NETL-MGN August 2001 Groundwater Data for "A Aquifer," . . . . . . . . . . . . 86

24 NETL-MGN August 2001 Groundwater Data for "B-C Aquifer" . . . . . . . . . . . . 87 


\section{Executive Summary}

No significant environmental problems were identified at the National Energy Technology Laboratory (NETL) sites in Morgantown (MGN), Pittsburgh (PGH), Tulsa (NPTO) and Fairbanks (AEO) during 2001. No radionuclides were released from the sites during 2001. The sites maintain two major environmental programs: waste management, and environmental media and release management. These two programs encompass waste handling, storage, and disposal, waste minimization and pollution prevention, air quality emissions, surface-water discharges, groundwater impacts, industrial wastewater discharges, and spill control procedures. The Morgantown and Pittsburgh sites currently maintain complete monitoring programs for groundwater, stormwater discharge, laboratory wastewater discharge, and meteorological data. In addition, an annual air emissions inventory is prepared.

A comprehensive Directives Program aimed at managing environmental, safety, health requirements, and risks was initiated in 1997, continued through subsequent years, and will be completed in 2003. The primary objective of the program is to identify and implement standards that will protect the health and safety of workers, public, and the environment. This program started with a careful and thorough analysis of risks confronting workers and the communities surrounding NETL sites. Following this analysis, requirements and best management practices were evaluated to determine how requirements could best be used to advance the mission of NETL. Teams of subject-matter experts analyzed the work assigned to determine potential hazards and identify ways to remove or control those hazards. In 2001, NETL developed or revised a series of directives in two major areas: safety analysis and review (SAR) processes, and integrated safety management (ISM) directives. SAR directives were issued for research and development (R\&D) operations, support operations, and facilities. ISM directives were released on management processes, such as standards maintenance, performance measures, assessments, corrective actions, lessons-learned, and training.

In conjunction with the Directives Program, the use of the voluntary environmental management system, ISO 14001, was evaluated. This includes the only international environmental management standard to which an entity can be certified. NETL is using the specifications and guidance from this standard to identify an effective environmental management system for the NETL sites. An outside consultant performed an environmental management system assessment (also referred to as an initial environmental review), as referenced in ISO 14004. The objective of the assessment was to determine the degree to which NETL's existing integrated safety management system (ISMS), safety analysis review system (SARS), and environmental management programs conformed with the ISO14001 Environmental Management System (EMS) standard and the United States Environmental Protection Agency's (EPA) Code of Environmental Management Principles.

A performance measurement system continued to be maintained during 2001 to assist in evaluating how effectively activities at NETL meet mission-critical goals and how well missions and strategies are connected in the DOE strategic plan. This system also provides data to assist in gauging performance against the DOE critical success factors, that is, performance against technical objectives. Various environmental milestones can be tracked to completion, thus giving NETL measures by which to gauge the sites' goals of remaining in regulatory compliance and achieving best-in-class environmental performance. 


\section{Introduction}

The National Energy Technology Laboratory (NETL), located in Morgantown, West Virginia, Pittsburgh, Pennsylvania, Tulsa, Oklahoma, and Fairbanks, Alaska, is a multi-purpose laboratory owned and operated by the U.S. Department of Energy (DOE). NETL conducts and implements science and technology development programs for the DOE in energy and energy-related environmental systems. Our organization, formerly the Federal Energy Technology Center, was established in 1996 through consolidation of Energy Technology Centers at Pittsburgh and at Morgantown. In December 1999, NETL was designated the DOE's 15th national laboratory. In August 2000, the National Petroleum Technology Office (NPTO) in Tulsa was assimilated into NETL; and in September 2001, NETL opened the Arctic Energy Office (AEO) in Fairbanks to work with the University of Alaska and other state entities to identify and promote energy-related research in arctic areas. Environmental activity performed at NPTO and AEO in CY 2001 is included in this report. NETL is a matrix organization; that is, employees at the Morgantown, Pittsburgh, Tulsa and Fairbanks sites operate organizationally under the same management team.

NETL is the fossil energy laboratory for the DOE, providing expertise in fossil energy supply, delivery, and end-use technologies. The organization's mission is to (1) resolve the environmental, supply, and reliability constraints of producing and using fossil resources; and (2) support the development and deployment of environmental technologies to clean up DOE's weapons complex. NETL's vision is to be the preferred provider of energy technology and policy options that benefit the public.

As a federal organization, NETL conducts both onsite research and development, and supports offsite research and development through contracted programs. A Strategic Center for Natural Gas (SCNG) and six onsite research focus areas were created. The six focus areas are composed of the following: Vision 21 Advanced Power Systems (pollution- free modular energy plants), Gas Energy Systems Dynamics (gaseous-fueled power generation systems), Environmental Research (air, soil, and water characterization/treatment), Ultraclean Fuels (for high-efficiency transportation systems), Carbon Sequestration Science (stabilizing atmospheric CO2 levels), and Computational Energy Science (virtual demonstrations of energy plants of the future). NETL's NPTO site provides oversight of research activities used to develop environmentally acceptable solutions to oil and gas exploration and production.

This Site Environmental Report is the sixth merged environmental analysis performed on the Pittsburgh and Morgantown sites, and the second merged environmental analysis performed on Pittsburgh, Morgantown, and Tulsa. We have dedicated ourselves to achieving a seamless environmental program. However, since all of the sites are in different states (West Virginia and Pennsylvania sites are more than 60 miles apart, and the Oklahoma site more than 900 miles apart) with different regulatory agencies, some reporting and monitoring issues must be discussed separately in this report. 


\section{Compliance Summary}

During 2001, NETL conducted numerous activities to comply with federal, state, and local regulations and internal requirements and Department of Energy (DOE) policies. This report provides information about activities and data related to compliance. The NPTO and AEO sites consist only of leased commercial office space which requires only minimal environmental compliance activity. This document does not address regulations where no action was required or there is no new information to report.

Compliance programs were conducted in areas such as air, water, soil, waste, and community "Rightto-Know." All solid hazardous wastes were managed and removed from the merged sites within allowable accumulation times specified in the Resource Conservation and Recovery Act (RCRA), and state regulations. Table 1 is a summary of environmental permits in 2001.

\section{Table 1. Summary of Environmental Permits}

\begin{tabular}{|c|c|c|}
\hline Permit Type & Permit Number & Status \\
\hline Air & $\begin{array}{l}\text { MGN: } \\
\text { R13-1768 } \\
0610064 \\
\text { PGH: } \\
7032056-000-00500 \\
7032056-000-00501 \\
7032056-000-0800\end{array}$ & $\begin{array}{l}\text { MGN: } \\
\text { West Virginia Division of Air Quality issues the permits. Right to } \\
\text { Construct and Certificate to Operate SynGas Generator/PDU. } \\
\text { PGH: } \\
\text { Allegheny County issues the permits. Natural gas boilers used for heating } \\
\text { buildings and one gas-coal fired research unit. }\end{array}$ \\
\hline $\begin{array}{l}\text { Water (non- } \\
\text { NPDES) }\end{array}$ & $\frac{\mathrm{PGH}}{\mathrm{GF}} 31062.008$ & $\begin{array}{l}\text { Industrial Sewer Use Permit issued by Gannett Fleming Engineers under } \\
\text { contract with the Pleasant Hills Authority. Regulates certain constituents of } \\
\text { process/laboratory wastewater placed into the sanitary sewer system. } \\
\text { Three Notices of Violation (free cyanide, mercury, and pH) were issued in } \\
2001 \text {. }\end{array}$ \\
\hline Water (NPDES) & $\begin{array}{l}\text { MGN: } \\
\text { MUB Permit No. } 012 \\
\text { WV0111457 } \\
\text { PGH: } \\
\quad \begin{array}{l}\text { Part I - PA0025844 } \\
\text { Part II - } 0297201\end{array}\end{array}$ & $\begin{array}{l}\text { MGN: } \\
\text { All monitored parameters were within permit limitations during } 2001 . \\
\underline{\text { PGH: }} \\
\text { Part I for a National Pollutant Discharge Elimination System (NPDES) } \\
\text { stormwater discharge permit issued by PaDEP. Part II for an industrial } \\
\text { settling weir owned by NIOSH. All monitored parameters were within } \\
\text { permit limitations during } 2001 .\end{array}$ \\
\hline Storage Tanks & $\begin{array}{l}\text { PGH: } \\
02-81183008 \mathrm{~A} \\
02-81183009 \mathrm{~A} \\
02-81183010 \mathrm{~A} \\
02-81183012 \mathrm{~A}\end{array}$ & Aboveground storage tank permits issued by PaDEP. \\
\hline
\end{tabular}




\begin{tabular}{|l|l|l|}
\hline Asbestos & PGH: & Asbestos Abatement Permits Issued through the Allegheny County \\
& PAA - 010683 & Pennsylvania, Health Department, Air Pollution Division. \\
PAA - 010018 & \\
PAA - 010184 & \\
PAA - 010122 & \\
& PAA - 010121 & \\
& PAA - 010017 & \\
& PAA - 000517 & \\
& PAA - 000516 & \\
PAA - 000519 & \\
\hline
\end{tabular}

\subsection{Comprehensive Environmental Response, Compensation, and Liability Act}

The Morgantown, Pittsburgh, Tulsa, and Fairbanks sites had no Comprehensive Environmental Response, Compensation, and Liability Act (CERCLA) activities in 2001; however, the following sections describe CERCLA-related activity at remote sites in other areas of the United States that remain the total or partial responsibility of NETL. These areas continue to be monitored for appropriate environmental responses.

\section{Rock Springs, Wyoming}

In Rock Springs, Wyoming, the Rock Springs Oil Shale Retort site consists of 13 locations where insitu shale fracturing and retorting research were conducted. As a result of research activities, groundwater was contaminated with organic compounds that must be cleaned up to standards set forth in the Wyoming Environmental Quality Act. Although the Rock Springs site was not listed on the Federal Agency Hazardous Waste Compliance Docket, NETL proactively tasked the Tennessee Valley Authority (TVA) to conduct a Preliminary Assessment (PA) of the site in 1993, in accordance with CERCLA, to determine if the site should be placed on the national priority list (NPL). After reviewing the PA, which resulted in a score of 2, U.S. Environmental Protection Agency (EPA) Region VIII classified the site as "site evaluation accomplished" (SEA) under the Federal Superfund Program and notified NETL that the site would not be evaluated further for inclusion on the NPL. As a result, DOE must satisfy Wyoming state requirements as defined by the Wyoming Environmental Quality Act.

Pilot demonstrations were designed and constructed at Sites 4/7, 9, and 12. Air injection and bioremediation actions were undertaken at each of the three sites, with a more aggressive air sparge system used at Site 4/7, minimal aeration/water extraction and injection with nutrient injection demonstrated at Site 9, and minimal air injection/water extraction and injection at Site 12. The demonstrations were conducted through August 2000, at which time an evaluation was conducted to determine the preferred remedial alternative for each site.

Air sparge /bioremediation was determined to be the best remedial alternative for sites 4, 7, and 9. The air sparge systems were designed and constructed in 2001 and are operating as designed. Site 12 remains in a pilot study with bioremediation as the primary remedial action. Feasibility studies are being conducted at the Rock Springs site and the University of Wyoming, Environmental Engineering Department. Contaminant levels have been reduced by approximately $90 \%$ at sites 4 and 7, with site 9 reduced by approximately $70 \%$, as reflected in the most recent analytical data. 
An Environmental Assessment for the Rock Springs Oil Shale Retort Site was conducted in 2000. The Finding of No Significant Impacts was signed on July 31, 2000. Completion of the NEPA process allowed design and construction of the preferred remedial alternatives to go forward.

Construction of the system and support buildings began in September, 2000 at site 9, and completed in February, 2001. Thirty air injection wells were installed, with eight wells acting as either injection or extraction wells. Two 100-horsepower (HP) electric compressors deliver air to the Site 9 wells. Six additional wells were installed in the well field at Site 4/7 in 2001, and wells used in the pilot demonstration are now being used for site remediation. Four 15 HP compressors deliver air to an aggressive air sparge system in all of the 22 wells in the site $4 / 7$ well field. Sites $4 / 7$ and 9 continue to show reductions of Benzene, Ethyl Benzene, Toluene, and Xylene (BTEX). Three ground water wells were installed at site 6 in 2001 to determine contaminant level and extent and ground water samples were collected and analyzed. Contaminant levels ranged from 8 parts per billion (ppb) to $27 \mathrm{ppb}$. Additional wells will be installed if data gaps are present.

\section{Gillette, Wyoming}

In Gillette, Wyoming, the Hoe Creek Underground Coal Gasification site consists of three locations where coal was gasified in situ. As a result of the field tests, coal tars remain underground in two coal seams and in the channel sand overburden. Water flowing through the coal and the channel sand is leaching organic compounds from source materials into the groundwater, and contaminant levels have exceeded state regulatory limits. Annual pump and treat operations have been conducted during summer months as an interim measure to minimize any contaminated groundwater movement out of the boundaries of the R\&D permit area onto private lands. Contaminated groundwater has migrated onto one private landowner's property east of the permit area. From 1994 through 1996, in an attempt to contain the contamination on the permit area, approximately 14,127,000 liters (3,774,000 gallons) of water were pumped, treated by routing through an activated granular carbon system, and applied to the ground surface by a spray system through atomizing nozzles.

The Hoe Creek site was listed on the Federal Agency Hazardous Waste Compliance Docket on June 1, 1991. A preliminary assessment (PA) of the Hoe Creek site was conducted in 1993, in accordance with CERCLA requirements, to determine if the site should be placed on the NPL. After reviewing the PA, which indicated a score of 14, the EPA Region VIII Office classified the site as SEA under the Federal Superfund Program and notified NETL that the site would not be evaluated further for inclusion on the NPL. As a result, requirements imposed by the Wyoming Environmental Quality Act must be met.

On February 7, 1998, an air sparge/bioremediation system was completed at the Hoe Creek II area of the Hoe Creek site. Air is being injected into the Felix I and II aquifers through 64 wells that were completed during the construction phase. Two 75-HP electric compressors supply the air necessary for delivery to the groundwater system for air sparging actions. Groundwater samples were extracted three times per year, and occurred at 111 day intervals (Day 111, 222, 333). The balance of days per year are consumed by periods of shutdown prior to sampling, and start-up time periods before resumption of air sparging activities. 
Construction of the Hoe Creek III air sparge/bioremediation system was initiated during October 1998, and completed in February, 1999. Fifty air sparge wells were completed in the Felix I and II aquifers, with six wells installed as a sparge curtain down-gradient from the well field. Two 100-HP electric compressors supply the air necessary for delivery to the groundwater system for air sparging actions. Groundwater samples were collected three times per year, and occurred at Day 111, 222, and 333.

The Hoe Creek II and III systems operated as designed, with no major problems, during calendar year 2001. Ground water contaminant levels continue to be reduced, with only 3 of the 27 wells in the semi-annual sampling network showing BTEX contaminants. Total BTEX contaminant values ranged from 6 parts per billion (PPB) to 48 PPB. Monitor wells off-site showed no contaminant levels. It is anticipated that the air sparge/bioremediation systems at Hoe Creek II and III will continue operation for up to 5 years. Periodic 6 month shut-down periods to evaluate contaminant rebound levels in the ground water, as recommended by the Wyoming Department of Environmental Quality (WDEQ), will be conducted. Groundwater remediation must continue until water quality is returned to baseline conditions or to a class of use through "best practicable technology," as required by the WDEQ.

\section{Hanna, Wyoming}

The Hanna Underground Coal Gasification site's experiments were conducted in the 1970's, and the WDEQ approved groundwater restoration for the site. Revegetation of the site surface remains to be accomplished prior to the WDEQ giving a final release and allowing termination of the R\&D (License) permit. A revegetation evaluation, conducted on reclaimed areas on the permit area in 1998, indicated vegetation density, productivity, and species diversity are close to satisfying the WDEQ requirements for final release. It was determined by the WDEQ during the annual inspection in 2001 that bond release and permit termination could be completed by 2003 .

The Rocky Mountain I Underground Coal Gasification site's experiments were conducted in the late 1980's, and the WDEQ has approved groundwater restoration for the site. Vegetation cover, productivity, species diversity, and shrub density data must be collected in 2002 and 2003 to satisfy all requirements for the WDEQ and the federal Office of Surface Mining. Activities in 2001 consisted of the Annual Inspection by the WDEQ, spraying Canada Thistle to reduce the infestations of noxious weeds on the R \& D Permit area, and conducting preliminary evaluations for vegetation cover, species diversity, and shrub density. Final reclamation performance bond release is expected in 2004 .

\subsection{Superfund Amendment and Reauthorization Act}

Title III of the Superfund Amendment and Reauthorization Act (SARA) of 1986 is known as the Emergency Planning and Community Right-to-Know Act (EPCRA). This act requires owners or operators of facilities that have certain hazardous chemicals on their site to provide information on the release, storage, and use of those chemicals to organizations responsible for emergency response planning. Executive Order 12856, signed by President Clinton on August 3, 1993, directs all federal agencies to comply with the requirements of EPCRA, including SARA 313 Toxic Release Inventory Program. 
All EPCRA reporting requirements pertinent to NETL have been met at the Morgantown and Pittsburgh sites. Table 2 identifies those requirements for which NETL has filed or will be required to report in the event of an occurrence. Tulsa and Fairbanks do not require EPCRA reporting

Section 302 of EPCRA requires the owner or operator of any facility at which an extremely hazardous substance is present in amounts equal to or greater than specified threshold planning quantities to notify the State Emergency Response Commission (SERC) that the facility is subject to the emergency planning requirements. Section 303 of EPCRA requires the facility to designate a facility representative to participate in local emergency planning as a facility emergency response coordinator. The Pittsburgh site has previously notified the emergency response commission under Sections 302 and 303, and periodically updates emergency contact information with revised Section 311/312 submittals. The Morgantown and Pittsburgh sites fall under the requirements of EPCRA 304, and in the event of a release are subject to the emergency notification requirements under Section 103(a) of the CERCLA of 1980. No releases required emergency notification during this 2001 reporting period.

Table 2. Emergency Planning and Community Right-to-Know Act Reporting

\begin{tabular}{|l|l|l|l|}
\hline \multicolumn{1}{|c|}{ Reporting Requirements } & \multicolumn{1}{|c|}{ Yes } & \multicolumn{1}{|c|}{ No } & $\begin{array}{c}\text { Not } \\
\text { Required }\end{array}$ \\
\hline EPCRA 302-303: Planning Notification & $\mathrm{X}(\mathrm{PGH})$ & & $\mathrm{X}$ (MGN) \\
\hline EPCRA 304: EHS Release Notification & $\mathrm{X}$ & & \\
\hline EPCRA 311-312: MSDS/Chemical Inventory & $\mathrm{X}$ & & \\
\hline EPCRA 313: TRI Reporting & & & $\mathrm{X}$ \\
\hline
\end{tabular}

Note: Because of differences in the hazards at each site, the EPCRA reporting requirements for Section 302 and 303 are not the same at the two sites.

SARA Title III requirements call for reporting all hazardous chemicals present at the facility during the preceding calendar year in amounts equal to or greater than 10,000 pounds, extremely hazardous substances at the facility in an amount greater than or equal to 500 pounds (or 55 gallons), or the Threshold Planning Quantity (TPQ), whichever is less. Table 3 lists those chemicals reported by NETL for 2001. Section 312 directs the owner or operator to prepare or have a material safety data sheet (MSDS) available for hazardous chemicals, and to submit an emergency and hazardous chemical inventory form by March 1 of each year, if the amount of the chemical equals or exceeds the TPQ. NETL maintains an active inventory of all hazardous materials on site along with the MSDS for each of these substances. The state and local emergency planning committees and local fire departments have been advised of all materials, quantities, and their location at the NETL sites. MSDS information on all materials is available. 
Table 3. SARA Title III, Tier II Chemical Inventory Reporting List

\begin{tabular}{|c|c|c|l|l|}
\hline $\begin{array}{c}\text { Chemical } \\
\text { Name }\end{array}$ & $\begin{array}{c}\text { Quantity } \\
\text { (Ib) }\end{array}$ & $\begin{array}{c}\text { TPQ } \\
\text { (lb) }\end{array}$ & \multicolumn{1}{|c|}{$\begin{array}{l}\text { Physical } \\
\text { Hazards }\end{array}$} & Health Hazards \\
\hline $\begin{array}{c}\text { Nitrogen } \\
(\text { MGN) }\end{array}$ & $10,000+$ & 500 & $\begin{array}{l}\text { Fire } \\
\text { Pressure } \\
\text { Reactivity }\end{array}$ & Acute \\
\hline $\begin{array}{c}\text { Hydrogen sulfide } \\
\text { (MGN) }\end{array}$ & $<100$ & Fire & Immediate (Acute) \\
\hline $\begin{array}{c}\text { Coal } \\
(\text { MGN) }\end{array}$ & $10,000+$ & & Fire & Chronic \\
\hline $\begin{array}{c}\text { Alumina } \\
(\text { MGN) }\end{array}$ & $<10,000$ & 10,000 & Pressure & Immediate (Acute) \\
\hline $\begin{array}{c}\text { Liquid nitrogen } \\
\text { (PGH) }\end{array}$ & 99,400 & Immediayed (Chronic) (Acute) \\
\hline
\end{tabular}

Submission of the Tier II Hazardous Chemical Inventory Form meets Section 312 requirements under the Pennsylvania Hazardous Material Emergency Planning and Response Act (Act 165). Section 313 of EPCRA, the Toxic Release Inventory (TRI) Reporting Program, requires the owner or operator of certain facilities that manufacture, process, or otherwise use listed toxic chemicals above threshold amounts to submit to EPA and designated State officials annual toxic chemical release inventory forms (Form R) for such toxic chemicals released into the environment. NETL did not exceed the threshold amounts for the listed toxic chemicals and thus was not required to submit a Form R.

\subsection{Clean Air Act}

Air pollutant emissions are regulated under the Clean Air Act (CAA) as amended (42 USC 7401 through 7642). EPA's regulations are contained in 40 U.S. Code of Federal Regulations (CFR) 50 through 87.

West Virginia regulates ambient air quality through the West Virginia Department of Environmental Protection (WVDEP) Division of Air Quality. The West Virginia Air Pollution Control Regulations are in Title 45 WV Code; and Series 1-7a, 10, 11, 13-15, and 17-26.

Pennsylvania regulates ambient air quality at the Pittsburgh site through the Allegheny County Health Department's Bureau of Air Quality Control in Pittsburgh, Pennsylvania. The Pennsylvania Air Pollution Control Regulations are in 25 PA Code, Chapters 123, 127, 131, 135, and 139. The Allegheny County regulations are in the Air Pollution Control Article XXI.

NETL does not fall under the National Emission Standards for Hazardous Air Pollutants (NESHAP) for radionuclide emissions (40 CFR 61, Subpart H) at either the Pittsburgh (PGH) or the Morgantown (MGN) sites. Neither site reported any radionuclide dose equivalents in its 2001 annual report. Emissions at the sites do not appear to be significant, as shown in Table 4. Total estimated air emissions decreased from 2000 to 2001 . There were no air quality permit exceedances or non- 
compliances during 2001.

Table 4. Estimated Air Emissions for 2001

\begin{tabular}{|l|c|c|}
\hline \multirow{2}{*}{\multicolumn{1}{|c|}{ Pollutant }} & MGN & PGH \\
\cline { 2 - 3 } & \multicolumn{2}{|c|}{ (tons per year) } \\
\hline Nitrous Oxides $\left(\mathrm{NO}_{x}\right)$ & 6.6 & 0.892 \\
\hline Sulfur Dioxide $\left(\mathrm{SO}_{2}\right)$ & 0.029 & 3.41 \\
\hline Carbon Monoxide $(\mathrm{CO})$ & 1.6 & 0.375 \\
\hline $\begin{array}{l}\text { Volatile Organic } \\
\text { Compounds (VOC) }\end{array}$ & 2.4 & 0.155 \\
\hline Particulates & 0.65 & 6.941 \\
\hline
\end{tabular}

\section{Air Permits}

NETL held three air permits in effect during 2001, issued by the Allegheny County Health Department for the Pittsburgh site. One permit (number 7032056-000-00500) was for a 4,500,000 Btu/hr Cleaver Brooks Natural Gas Boiler, located in Building 922. The second permit (number 7032056-00000501) was for three RayPak Finned Coppertube Boilers, in Building 922, each having a $1,630,000 \mathrm{Btu} / \mathrm{hr}$ input rating. Permit number 7023056-000-00800 was for the $500 \mathrm{lb} / \mathrm{hr}$ gas and coalfired research unit located in Building 86. During 2001, administratively the site continued to be a synthetic minor source under CAA Title $\mathrm{V}$ by voluntarily limiting to a 2,400 hours maximum the operating time per year at $100 \%$ coal.

Air permits for the Pittsburgh site are obtained from the Allegheny County Health Department's Bureau of Air Quality Control in Pittsburgh, Pennsylvania. Allegheny County regulates the air program outlined by EPA and Pennsylvania Department of Environmental Protection (PaDEP).

As part of Article XXI, and to comply with Title V of the 1990 Clean Air Act Amendments, NETL submitted an application in 1996 for one new plant-wide permit for the Pittsburgh site. A comprehensive annual air emissions inventory was an integral part of the application. The site was notified that the application was accepted as administratively complete. NETL is currently awaiting the technical review of the application.

On May 1, 1995, the Morgantown site received air permit No. R13-1768 from the West Virginia Division of Air Quality (OAQ) and constructed an experimental syngas generator/hot gas desulfurization process development unit (PDU) at the site. NETL renewed the certificate annually to operate the syngas generator/PDU (Certificate 061 0064) from July 1 through June 30 in 2000 and 2001. An integrated shakedown of the syngas generator and PDU occurred in the spring and summer of 2001, followed by test program operations that will be used to develop gas cleanup technologies for advanced integrated coal gasification combined-cycle power generation systems. Operating summaries required by the PDU permit are submitted quarterly. 


\section{Emission Source Inspections}

EPA requires all major air sources to be inspected annually to ensure compliance with existing site air permits. An inspection of the Pittsburgh site's air emission sources was conducted by the Allegheny County Health Department's Air Quality Program Division. Results of the inspection showed that the site was in compliance.

The Pittsburgh site maintained three 30-foot meteorological towers that monitored temperature, relative humidity, precipitation, and wind speed. Data were collected twice per week, and were used in the site's heating, ventilation, and air conditioning (HVAC) maintenance programs, emergency preparedness program, and air monitoring program.

In addition, the Pittsburgh site conducted a stratospheric ozone depletion program to recover and reclaim chlorofluorcarbons (CFC) from HVAC equipment. All CFC-containing equipment was inventoried, and measures are being taken to phase out these materials.

In Morgantown, site air emissions were inventoried quarterly to assess whether permit conditions were being met and if any additional permits or permit modifications were needed. Emissions were either measured, estimated by EPA methods, or projected by combustion and mass balance calculations. The 2001 air emissions inventory revealed that emissions were minor and were consistent with the estimations made the previous year. The site is a minor source of emissions, and no Title $\mathrm{V}$ permit is required.

Data from the 150-foot free-standing meteorological tower were used to report stormwater information. Additionally, the Emergency Operations Center used the data to predict the effects of accidental and non-routine releases.

\subsection{Clean Water Act and the National Pollutant Discharge Elimination System}

Wastewater discharges are regulated under the Clean Water Act (CWA) (33 USC 1251 et seq.) and subsequent federal regulations (40 CFR Parts 121, 122, 125, 136, 405-471). West Virginia and Pennsylvania are National Pollutant Discharge Elimination System (NPDES)-authorized states. The West Virginia NPDES regulations are codified in Title 46-West Virginia Codes 1 and 2. The Pennsylvania NPDES regulations are codified in 25 Pennsylvania Code Chapters 16, 91-95, 97, 101, and 102.

The Pittsburgh site of the NETL is essentially divided into two distinct portions - the areas north of Wallace Road and those south of Wallace Road. As described below, the north area houses all the laboratory and process areas for the site. Treated effluent from the site's wastewater treatment facility (WWTF) and sanitary sewage from this area are routed to- and given final treatment in- the Pleasant Hills publicly-owned municipal sewage treatment facility. Collected stormwater exits the site's north area via the north storm sewer system which enters nearby Lick Run through the NPDES-permitted North Outfall (001). The south area of NETL-Pittsburgh houses the site administrative, project 
management, and site maintenance functions. All sanitary sewage is routed to, and treated in, the Clairton publicly-owned municipal sewage treatment facility. Collected stormwater exits the site's south area via the south storm sewer system which enters nearby Lick Run through the NPDESpermitted South Outfall (002).

NETL shares the north portion of the 238-acre Bruceton Research Center with two other federal agencies, the U.S. Department of Health and Human Services, Centers for Disease Control, National Institute for Occupational Safety and Health (NIOSH) and the U.S. Department of Labor Mine Safety and Health Administration.

All treated laboratory and process wastewater from the Pittsburgh site is regulated at the local level under the Pleasant Hills Industrial Sewer Use Permit Program. Treatment in the site WWTF consists of flow equalization with subsequent neutralization by the addition of caustic soda or ferric chloride. Metals and particulates are removed by agglomeration in the flocculation tank, coupled with solids separation in the plate separator with final removal in the filter press. An activated clay/activated carbon filtration system was added in June 2000 to provide additional removal of organics and metals from the treated wastewater prior to discharge into the sanitary sewer. The effluent can be recirculated if additional predischarge treatment is required.

NETL was issued an Industrial Sewer Use Permit (ISUP) in December 1999 by the PHA as required by the Clean Water Act. The conditions placed on NETL by the permit limits the quantity of effluent constituents (free cyanide, phenolics, mercury, copper, chloroform, and $\mathrm{pH}$ ) that may be discharged in the wastewater stream. The permit requires NETL to submit to PHA's consulting engineering firm, Gannett Fleming, wastewater analysis data semi-annually for the Building 74 effluent. In addition, NETL provides Gannett Fleming with monthly wastewater sampling results and a self-monitoring report semiannually for the subinterceptor location. NETL is also required to prepare an annual industrial waste survey report which contains no sampling data. This information is used by the PHA to determine whether any discharges of the treated effluent were in excess of the local limits and required issuance of a NOV.

NETL received three Notice of Enforcement Action - Letter of Violation (NOV) during 2001. One NOV was received on January 8, 2001, another on April 23, 2001, and a third on May 22, 2001. The January 8, 2001 NOV was the result of an exceedance of free cyanide on October 26, 2000. The April 23, 2001 NOV was the result of an exceedance of mercury on January 30, 2001. The May 22, 2001 NOV was the result of an exceedance for $\mathrm{pH}$ on March 27, 2001 (see section 3.6.2 Environmental Occurrences, page 37 for a more complete description of the three NOVs received in 2001). No penalties were assessed for these three NOV's. Not all exceedances of permit limits resulted in the issuance of a NOV from the PHA. Table 8 presents the monthly wastewater effluent sampling results that includes the two exceedances in 2001 that resulted in the issue of a NOV, as well as three other exceedances that were not cited by the PHA (exceedances are indicated by shading). Table 9 presents the semiannual wastewater effluent sampling results for Building 74 that are required by the PHA ISUP, as well as the semi-annual sampling at the subinterceptor location that is not required by the permit. There are four exceedances in Table 9 (indicated by shading) that did not result in the issue of a NOV, including four separate grab samples representing a single exceedance. 
The subinterceptor pipe into which NETL's sanitary sewage is discharged is separate from the interceptor into which the treated laboratory/process wastewater is discharged. Periodic sampling/analysis of the sanitary sewage from all three federal agencies entering the common site sanitary sewage system subinterceptor is also performed by the Pleasant Hills Authority (PHA). Analytes for this waste stream are the same as for the industrial wastewater. Sampling of the effluent in this shared subinterceptor location revealed that the NETL-generated sanitary sewage contribution was not a source of any violations. Consequently, NETL was removed from the subinterceptor stream sampling requirement beginning in 2001. However, NETL continues to perform sampling of this wastewater stream at the request of the PHA.

NETL implemented a program to manually transfer the Building 141 laboratory wastewater holding tank (LWHT) to the WWTF for treatment. This has allowed greater control over the quality of the treated effluent, especially in view of the installation of the additional filtration system. In addition, since this has removed the LWHT as a source of direct discharge to the sanitary sewer, sampling/analysis of the LWHT water is no longer required.

PGH received an NPDES Storm Water Permit, No. PA0025844, in June of 1996. PGH is required to monitor and report the results of two outfalls quarterly (see Table 7). Outfall 001 (north outfall) parameters are flow, suspended solids, $\mathrm{CBOD}_{5}$, oil and grease, aluminum, iron, manganese, lead, mercury, pH, and ammonia. Outfall 002 (south outfall) parameters are flow, suspended solids, aluminum, iron, manganese, lead, $\mathrm{pH}$, and ammonia. A third monitoring point, designated as Outfall 101, which originates in the NIOSH Safety Research Coal Mine and exits the site via outfall 001 consists of acid mine water which is treated and sampled/analyzed prior to discharge. Outfall 101 parameters are flow, suspended solids, iron, manganese, and $\mathrm{pH}$. This sampling/analysis occurs weekly and is reported monthly, separate from the required quarterly reporting for Outfalls 001 and 002.

At MGN, NETL retained two permits under the NPDES during 2001. One permit, Morgantown Utility Board (MUB) Permit No. 012, was issued by the MUB for the discharge of sanitary and pretreated industrial wastewater to the City of Morgantown's municipal sewer system POTW. This permit was renewed in June 2000. Industrial wastewater consists of laboratory sink wastewater, motor pool wastewater, condensates, and boiler blow-down. The wastewater is pretreated by a 16-footdiameter clarifier and a $12 \times 16$ foot sludge drying bed. The wastewater is also treated to control $\mathrm{pH}$. All monitored parameters were within permit limitations in 2001.

The other Morgantown permit issued under the NPDES was WV/NPDES Permit No. WV0111457, General Permit Registration No. WVG610042, issued by the West Virginia Department of Commerce, Labor and Environmental Resources Division of Environmental Protection, for the discharge of stormwater to Burroughs Run and West Run (see Table 7). As stated in the WV/NPDES permit approval letter, NETL-MGN is required under the terms and conditions of this permit to (1) monitor and report semiannually to the State of West Virginia from outfalls 002, 005, and 010; and (2) maintain a stormwater pollution prevention plan and a groundwater protection plan, both to be retained on site and made available for state review as requested .

\subsection{Resource Conservation and Recovery Act}


The RCRA (42 U.S. Code 6901 et seq.) regulates the generation and management of solid wastes at the federal level, including those designated as hazardous. EPA's hazardous waste regulations are codified in Title 40 CFR Parts 260-271. The WVDEP (Morgantown) and PADEP (Pittsburgh) are authorized to oversee much of the EPA's requirements. No notices of violations were awarded by either party in 2001.

NETL complied with all regulations, by carefully and diligently removing hazardous waste in a timely manner at all sites. NETL is a large quantity generator in both Pittsburgh and Morgantown, and does not generate hazardous waste in Tulsa or Fairbanks. The Pittsburgh EPA ID is PA8890031869 and the Morgantown EPA ID is WV7890031886. The total for RCRA Hazardous Waste was 172 cubic feet in Pittsburgh and 830 cubic feet in Morgantown. Morgantown's number was high due to the fact that a large amount of metal, painted with lead based paint, was shipped off site in a roll-off box as hazardous waste so that paint could be later removed and the metal would then be recycled.

The NETL sites are in compliance with respect to DOE Orders, respective state regulations, RCRA and the other applicable EPA Regulations with respect to waste and waste removal. Additionally, DOT regulations are strictly adhered to for waste removal. Compliance is ensured via vigilant contractor and federal personnel involvement. Hazardous Waste Manifests are looked over carefully at least twice by contractor and federal personnel for omissions and errors.

Table 5 shows the status of aboveground storage tanks at Pittsburgh and Morgantown.

Table 5. Aboveground Storage Tanks ${ }^{1}$

\begin{tabular}{|l|l|c|c|l|}
\hline \multicolumn{1}{|c|}{ Location } & \multicolumn{1}{|c|}{ Description } & $\begin{array}{c}\text { Capacity } \\
\text { (U.S. } \\
\text { Gallons) }\end{array}$ & $\begin{array}{c}\text { Active or } \\
\text { Inactive }\end{array}$ & \multicolumn{1}{|c|}{ Comments } \\
\hline NETL-PGH & Waste Oil Holding Tank & 950 & Inactive & Taken out of service in 1992. \\
\hline NETL-PGH & Caustic Soda Tank & 1,500 & Active & \\
\hline NETL-PGH & Ferric Chloride Tank & 1,500 & Active & \\
\hline NETL-PGH & Heating Oil Tank & 2,200 & Inactive & Taken out of service in 1990. \\
\hline $\begin{array}{l}\text { NETL-MGN } \\
\text { Outside B13 }\end{array}$ & $\begin{array}{l}\text { Diesel Fuel Storage } \\
\text { (Double Tank) }\end{array}$ & 50 & Active & $\begin{array}{l}\text { Used for research } \\
\text { equipment. }\end{array}$ \\
\hline $\begin{array}{l}\text { NETL-MGN } \\
\text { Outside B29 }\end{array}$ & $\begin{array}{l}\text { Diesel Fuel Storage } \\
\text { (Double Tank, Bermed) }\end{array}$ & 250 & Active & Vehicle fuel. \\
\hline $\begin{array}{l}\text { NETL-MGN } \\
\text { Outside B29 }\end{array}$ & $\begin{array}{l}\text { Gasoline Fuel Storage } \\
\text { (Double Tank, Bermed) }\end{array}$ & 500 & Active & Vehicle fuel. \\
\hline $\begin{array}{l}\text { NETL-MGN } \\
\text { Outside B34 }\end{array}$ & $\begin{array}{l}\text { Diesel Fuel Storage } \\
\text { (Double tank) }\end{array}$ & 50 & Active & Emergency generator fuel. \\
\hline $\begin{array}{l}\text { NETL-MGN } \\
\text { Outside Navy } \\
\text { Facility }\end{array}$ & $\begin{array}{l}\text { Diesel Fuel Storage } \\
\text { (Double Tank) }\end{array}$ & 1,000 & Active & Emergency generator fuel. \\
\hline
\end{tabular}

1. Pennsylvania requires all aboveground storage tanks above a specific volume to be registered. West Virginia does not require registration of

aboveground storage tanks. Therefore, all of the aboveground storage tanks at the Morgantown site are shown in this table, while only the aboveground tanks that require registration are listed for the Pittsburgh site. 


\subsection{Safe Drinking Water Act}

Drinking water requirements are codified under the Safe Drinking Water Act (SDWA) (42 USC 300f through 330j - 11), and regulated in 40 CFR Parts 141 through 143. NETL is classified as a nontransient, non-community water system under these laws and regulations. Because NETL does not provide treatment or storage of this water, the monitoring requirements of a public water supplier are not required; however, the Morgantown and Pittsburgh sites conducted sampling and analysis programs at selected potable water locations and compared samples against the SDWA primary and secondary regulatory standards.

MGN receives its potable water supply from the city of Morgantown. Samples were taken periodically from potable water locations and tested. No samples met or exceeded SDWA limits in 2001.

PGH receives its water supply from the Pennsylvania American Water Company. Fifty-seven primary and secondary drinking water contaminants were sampled at nine representative locations in 2001. In addition, 43 water coolers were sampled for concentrations of lead, copper, and $\mathrm{pH}$. All of the results of the sampling were below the primary maximum contaminant levels, therefore no corrective actions were taken.

\subsection{Toxic Substances Control Act}

Requirements for managing polychlorinated biphenyls (PCBs), asbestos, and lead are codified in Toxic Substances Control Act (TSCA) 15 USC 2601 to 2654. EPA regulations addressing PCBs and asbestos in conjunction with the TSCA are codified in 40 CFR 761 and 763, respectively. Asbestos is also regulated under CAA (40 CFR 61, Subpart M); U.S. Occupational Safety and Health Administration (OSHA) (29 CFR 1910.1001, 29 CFR 1926.1101); and Pennsylvania's Allegheny County Health Department (ACHD) Article XXI.

NETL typically initiates abatement action for four reasons: decommissioning/demolition operations; remodeling/reconstruction operations; asbestos floor tile concerns; and providing an "asbestos free" work place. NETL-PGH abated twenty-six cubic yards of asbestos waste in 2001 using four permits that were issued by the Allegheny County Health Department (ACHD). This included the abatement of offices and laboratories in various areas of buildings 58, 83 and 94. Both the Asbestos

Abatement/Removal Contractor (AA/RC) and the independent third party industrial hygiene monitoring companies were registered with the ACHD. All AA/RC employees were trained and licensed by both ACHD and the Pennsylvania Department of Labor and Industry. All asbestos containing waste was disposed in an EPA approved landfill.

All PCB containing transformers have been removed from the site or flushed to remove the PCBs and refilled with a non-PCB fluid during prior years. All fluorescent lamp ballasts were presumed to contain PCBs and were properly disposed in an EPA approved landfill. 
Small amounts of lead paint were removed with caustic paint remover in 2001. The waste was disposed in an EPA-regulated landfill. Steel structure with lead paint was disposed at a smelter, which captured the lead paint fumes in an EPA approved baghouse.

At the Morgantown site, all abatement of asbestos and asbestos-containing materials (ACM) was conducted by West Virginia licensed asbestos abatement contractors. All abated asbestos and ACMs was properly disposed in asbestos-approved landfills.

A full asbestos survey of all Morgantown site facilities was completed during 1992. No known friable asbestos remains on the Morgantown site. The current management plan for asbestos at NETL-MGN is to manage in place; abating asbestos and ACM only when it becomes necessary because of construction, renovation, or maintenance. Facility plans and work orders are reviewed during the planning stages for asbestos disturbance. Known ACM is labeled.

As part of a renovation project in Building 3 on the Morgantown site, tile mastic containing asbestos was abated from approximately 1000 square feet of floor. The abatement was conducted by a WV licensed abatement contractor. Various small asbestos abatement activities were completed throughout the year at various locations on site, primarily drilling holes through asbestos-content solid wall panels for new conduit or pipe runs.

All PCB transformers were removed from the MGN site during previous years.

A survey of lead-based paint at the Morgantown site was completed in early 1997. A priority list was made for lead paint removal projects, based on conditions of paint and proximity to workers. Lead paint has been abated on all fire extinguishers and other outdoor fire apparatus. A multi-year lead paint abatement plan for the site's pipe bridge supports has continued. A WV-licensed contractor did the abatement, and lead paint debris was disposed by the site support contractor hazardous waste personnel at an approved landfill.

\subsection{Federal Insecticide, Fungicide, and Rodenticide Act}

Pesticide requirements are codified under the Federal Insecticide, Fungicide, and Rodenticide Act (FIFRA) 7 USCS $\S \S 136$, et seq. EPA pesticide regulations are documented in 40 CFR, Parts 162, 166, and 171. Pennsylvania pesticide regulations are cited in $7 \mathrm{~Pa}$. Code 128. Allegheny County, Pennsylvania pesticide regulations are cited in ACHD Article III.

Pest control for buildings at the Morgantown site was performed monthly or as needed, and entailed spraying interior baseboards and corners. No FIFRA-regulated materials were stored onsite. The use of pesticides at MGN was limited to materials that are not classified by the EPA for restricted use. Compliance was verified by comparing the MSDS for the onsite material with the applicable standard. Pesticides were applied by qualified contractors using certified personnel. The only site personnel who applied pesticides were maintenance technicians. Occasionally over-the-counter sprays are used on nests built in, or on, outside equipment. MSDSs are obtained and kept for these sprays.

An integrated pest management program was implemented at the Pittsburgh site to comply with federal, 
state, and local pest management requirements, as well as Executive Orders. All pesticide/herbicide applicators were trained and licensed by the PaDEP. All pesticide and herbicide MSDS and all technical specification sheets were submitted for review and approval prior to use. No pesticides or herbicides were stored onsite. The applicator brought only the minimum quantity necessary for that day's work. Because there was no waste, there was no need to store the materials.

Pest control for buildings at the Pittsburgh site was limited to "banding" with aqueous solutions of Demand $\AA$ (dispersing Talstar ${ }^{\circledR}$ crystals on grassy surrounds of buildings and foundation spraying). Any indoor applications are limited to an as-needed basis. The Pittsburgh cafeteria was treated monthly with a "crack and crevice control" technique. A hand-pumped, atomizing spray tank-wand treated baseboards, door thresholds, and through-wall water pipes with an aqueous solution of Demand®. Sting

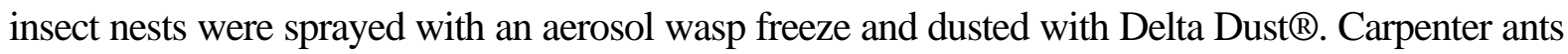
were treated with Demand®. Poison Sumac was treated with a mixture of Round-up® and HyVar®.

\subsection{National Environmental Policy Act}

The National Environmental Policy Act (NEPA - 42 U.S.C. 4321 et seq.) of 1969 established Federal policy for protecting environmental quality. Under this policy, an Environmental Impact Statement (EIS) must be prepared to evaluate the environmental consequences of any major Federal action that might have significant impact on the quality of the human environment. A Record of Decision would be prepared to document the Federal decision on a course of action determined subsequent to an EIS review. If the need for an EIS is not clear, if a proposed action has uncertain potential for environmental impacts, etc., but does not meet DOE=s criteria for preparation of an EIS, an Environmental Assessment (EA) would be prepared. Subsequent to preparing an EA, either a decision would be made to prepare an EIS or a Finding of No Significant Impact (FONSI) would be issued if an EIS was determined to be unnecessary.

Certain classes of actions that do not have a significant effect on the environment, either individually or cumulatively, can be categorically excluded from more in-depth NEPA review (i.e., preparation of either an EIS or EA). DOE=s NEPA implementing procedures (10 CFR 1021) identify those categories of excluded actions and the eligibility criteria for their application.

\section{Performance}

NETL conducts NEPA reviews for proposed on-site actions and off-site Federal actions, which are planned in cooperation with other governmental organizations, educational institutions, or private industry. During calendar year 2001, approximately 200 NEPA reviews resulted in categorical exclusions. All new on-site activities were covered by categorical exclusions.

During 2001, a draft Environmental Assessment was completed for DOE/EA-1309, Co-Utilization of Coal with E-Fuel ${ }^{\mathrm{TM}}$ from the SlurryCarb ${ }^{\mathrm{TM}}$ Process. This project would involve combustion testing of carbon-based fuel produced from a facility to be constructed at South Kearney, NJ, for processing municipal sewage sludge.

A Final Environmental Assessment (DOE/EA-1336) was prepared and a Finding of No Significant Impact was issued in 2001 for an Ocean Sequestration of $\mathrm{CO}_{2}$ Research Project. This project would 
evaluate and model the dispersion and dissolution of liquid $\mathrm{CO}_{2}$ droplets injected into the ocean at a depth of about 800 meters.

A draft Environmental Assessment (DOE/EA-1402) was issued for public participation in 2001 for the Port of Tillamook Bay Dairy Digester Project, a technology development effort in Tillamook County, $\mathrm{OR}$, to investigate energy recovery using farm animal manure.

During 2001, decisions were made to prepare Environmental Assessments for the following off-site projects:

- $\quad$ Gas-to-Liquids Fuels Production and Demonstration Project (DOE/EA-1417). This proposed action would provide funds for constructing a 70 barrel-per-day facility to produce clean liquid transportation fuels from natural gas at the Tulsa Port of Catoosa, OK.

- Demonstration of an Integrated Power Generation System for Coal Mine Waste Methane Utilization (DOE/EA-1416). This proposed action would result in providing funds to construct a facility in Monongalia County, WV, for demonstrating an integrated system that would use coal mine waste methane for the production of electric power.

- $\quad$ Enhanced Coal Bed Methane Production and Sequestration of CO2 in Unmineable Coal Seams (DOE/EA-1420). This proposed action would provide funds to test injection of carbon dioxide into a coal seam for both enhanced methane recovery and carbon sequestration. The project would be located in Marshall County, WV.

No new Environmental Impact Statement (EIS) decisions were made in 2001. Preparation of EIS documents continued at various levels for the following projects:

- $\quad$ Kentucky Pioneer Integrated Gasification Combined Cycle Demonstration Project (DOE/EIS0318) in Clark County, KY.

- $\quad$ Low Emission Boiler System Proof-of-Concept Project (DOE/EIS-0284) at Elkhart, IL.

- $\quad$ Clean Power from Integrated Coal/Ore Reduction (CPICOR) (DOE/EIS-0280) at Vineyard, UT.

- $\quad$ McIntosh Unit 4 Pressurized Circulating Fluidized-Bed Demonstration Project (DOE/EIS-0282) at Lakeland, FL (on hold).

\subsection{Federal Facility Compliance Act}

The Federal Facility Compliance Act (FFCA) is an amendment to RCRA, initiated as a result of States protesting the protection of federal facilities from fines or penalties. The congressional intent was to waive the sovereign immunity of federal agencies and require them to comply with the full range of enforcement tools available to all regulatory authorities. Under the FFCA, there is explicit authority to issue administrative compliance orders that are RCRA violations. Additionally, the FFCA requires the EPA to conduct annual inspections of federal facilities with RCRA Part B permits.

FFCA also encourages federal facilities to seek voluntary resolution to environmental challenges. NETL 
sites are not currently under onsite consent agreements and are not RCRA Part B facilities. However, NETL conducts their environmental programs according to applicable federal, state, and local regulations.

\subsection{Other Environmental Statutes}

The Pittsburgh site completed an ecological baseline risk assessment in June 1998. Based on the sitespecific and regional ecology, several ecological receptors are potentially at risk from contaminants at the sites. Contaminants were detected in the surface water, sediment, soil and groundwater in Pittsburgh. Potential receptors of contaminants in surface water and sediment include fish, benthic macroinvertebrates, other aquatic flora and fauna, and some terrestrial faunal species. Potential receptors of contaminants in soils include deer, rabbits, foxes, raccoons, birds and terrestrial flora (e.g., Scotch Pine trees, Black Locust trees, and Oak trees) and fauna.

An extensive, site-wide monitoring and risk assessment effort was conducted at the Morgantown site in 1995. The purpose was to investigate all known potential risk sources, including abandoned ponds, removed underground tanks, material storage areas. From this effort, a few small scale remediations were performed in order to reduce risks to human and ecological receptors to acceptable levels.

Wetlands, benthic macroinvertebrate, fisheries, herptofauna, avifauna, small mammals, terrestrial vegetation, and threatened and endangered species surveys of the Morgantown site were conducted in late summer 1992. The cultural resources investigation was conducted in fall 1992. A review of pertinent regulations, technical reports, and documents related to the Morgantown site was conducted to characterize the remainder of resources at the Morgantown site. Climate, air quality, geology, sediment, stormwater, land use, and human health and safety data were obtained from studies conducted in 1990, 1991, 1992, and 1993.

\subsubsection{Endangered Species Act}

The following steps were taking to ensure NETL is in compliance with the Endangered Species Act (ESA). The following agencies contracted for information regarding threatened and endangered species on and adjacent to the Morgantown site:

- $\quad$ Natural Heritage Program of the West Virginia Division of Natural Resources (WVDNR)

- $\quad$ U.S. Fish and Wildlife Service

- West Virginia University

- $\quad$ Marshall University Department of Biological Sciences

The U.S. Fish and Wildlife Service-West Virginia Field Office, the WVDNR Natural Heritage Program, and other sources listing critical habitat characteristics were consulted. Information obtained from these sources indicated that there is no documentation of rare, threatened, or endangered species in the vicinity 
of the NETL site in Morgantown, West Virginia. Additionally, the WVDNR Wildlife Resources Section knew of no rare species surveys conducted in the Morgantown facility area. The survey and delineation of threatened and endangered species habitats near the Morgantown facility was to be conducted, if these species were suspected of inhabiting the Morgantown site. Optimal habitat survey periods would encompass the normal growing season (i.e., May through September). Pursuant to the information received from the agencies contacted, it was determined that no threatened and endangered species inhabited the site.

The following agencies were contracted for information regarding threatened and endangered species on and adjacent to the Pittsburgh site:

- Pennsylvania Department of Environmental Protection

- $\quad$ U.S. Fish and Wildlife Service

- $\quad$ Pennsylvania Game Commission

- $\quad$ Pennsylvania Fish and Boat Commission

The United States Fish and Wildlife Service (FWS) maintains a list of federal endangered and threatened species of animals. The FWS responded on December 14, 1994 that, except for transient species, no federally listed or proposed threatened or endangered species under FWS jurisdiction are known to exist at the Pittsburgh site.

The Pennsylvania Fish and Boat Commission, Bureau of Fisheries and Engineering (PFBC) was contacted for information on Pennsylvania's state endangered and threatened species of fish, amphibians and reptiles. The PFBC responded in a letter dated December 6, 1994 that none of the fishes, amphibians, or reptiles the PFBC lists as endangered or threatened are known to occur at or in the immediate vicinity of the NETL Pittsburgh site.

The Pennsylvania Game Commission, Bureau of Wildlife Management, (PGC) has jurisdiction over wildlife and wildlife habitats in Pennsylvania. The PGC responded via letter dated December 7, 1994, that except for transient species, no state listed threatened or endangered species under PGC jurisdiction are known to exist at the NETL Pittsburgh site.

The Pennsylvania Natural Diversity Inventory (PNDI) is maintained by the PaDEP, Bureau of Forestry, with technical assistance from the Nature Conservancy and the Western Pennsylvania Conservancy. The PNDI contains information on rare, endangered, and threatened animals and plants; exemplary natural communities and special geologic features; and other natural features of Pennsylvania. No response has been received from this agency to date. However, a previous response from 1992 indicated that no confirmed resources of special concern were identified within the study area.

In addition to the agency correspondence, no threatened or endangered species were identified at the NETL Pittsburgh site during a terrestrial and aquatic ecological study conducted in 1981. Pursuant to the information received from those agencies contacted, it was determined that no threatened and endangered species were suspected of inhabiting the site. 


\subsubsection{National Historic Preservation Act}

The National Historic Preservation Act is not applicable. NETL has evaluated all potential landmarks at each site and determined that there are no historically significant landmarks that require preservation.

\subsubsection{Migratory Bird Treaty Act}

The Migratory Bird Treat Act is not applicable. NETL did not take any actions in 2001 that had, or was likely to have, a measurable negative effect on migratory bird populations. No migratory birds of any species were intentionally taken during the conduct of any program, activity or action, including but not limited to banding, marking, scientific collection, taxidermy, and depredation control.

\subsection{Executive Orders}

\subsubsection{E.O. 13148 -- "Greening the Government Through Leadership in Environmental Management"}

[Note: Please see section 2.2 of this report "Superfund Amendments and Reauthorization Act" for information on EPCRA as required by E.O. 13148].

Executive Order 13148, "Greening the Government through Leadership in Environmental Management," focuses on integrating environmental accountability into agency day-to-day decision making and longterm planning processes. The order establishes goals in the following seven areas: (1) Environmental Management Systems; (2) Environmental Compliance; (3) Right-to-Know and Pollution Prevention; (4) Reduction in Toxic Chemical Releases; (5) Reduction in Toxic Chemical, Hazardous Substance, and Other Pollutant Use; (6) Reduction in Ozone-Depleting Substances; and (7) Environmentally Beneficial Landscaping.

\section{Environmental Management Systems}

As part of NETL's efforts to implement an effective Environmental Management System (EMS), a self assessment, as referenced in the ISO 14004 Standard, was conducted in January 2001. The assessment examined NETL's Integrated Safety Management System and its Safety Analysis and Review System, as well as existing environmental management programs to determine the degree to which these programs conform with the ISO 14001 Standard and the U.S. EPA's Code of Environmental Management Principles. The assessment found that NETL currently has plans and procedures in place for: Legal and Other Requirements, EMS Structure and Responsibility, EMS Documentation, Emergency Preparedness and Emergency Response, and Checking and Corrective Action. In addition, plans and procedures were in place, but require revisions to comply with the following sections of the Standard: the Environmental Policy; EMS Planning; EMS Implementation and Operation; Communication; Documentation Control and Operational Control; Monitoring and Measuring; Records; EMS Audits; and Management Review. Finally, the assessment identified the following gaps: there were no Environmental Aspects, Objectives and Targets, or Environmental 
Management Programs; and there were inconsistencies in the areas of Training, Awareness, and Competence.

Following the assessment, a methodology was developed to identify the lab's environmental aspects and impacts. An EMS crosscutting team then identified the lab's "top-ten" significant environmental aspects, as well as corresponding objectives and targets. Environmental Management Plans were developed to address the specific objectives and targets.

\section{Environmental Compliance}

NETL plans to pursue certification for conformance with the ISO 14001 Standard. In preparation, NETL conducted its first internal audit of the EMS on November 28 and 29, and December 4, 2001. Five (5) findings of nonconformance with the standard and two (2) observations were identified. Findings included: (1) the environmental policy had not been effectively implemented and communicated to all employees; (2) most employees were not aware of their roles and responsibilities in achieving conformance with the environmental policy and procedures; (3) most employees did not understand the significance of Environmental Management Plans; (4) procedures for reviewing and revising EMS documentation have not been consistently implemented across the organization; and (5) out-of-date and missing MSDS sheets were noted in several work areas. Audit observations were noted in the areas of identifying training needs and records accessibility. The audit team also noted that there were a few employees who were very knowledgeable of the policy, procedures, and their impacts on the environment (in the machine shops and purchasing, and the manager of the energy program). All employees could identify the EMS Management Representative.

\section{Right-to-Know and Pollution Prevention}

Note: NETL's Pollution Prevention goals also include "green purchasing" or "affirmative procurement" activities. These activities are discussed in section 2.12.2, Executive Order 13101.

Based on the requirements of the Emergency Planning and Community Right-to-Know Act (EPCRA), agencies are required to inform the public and their workers of possible sources of pollution resulting from facility operation. The purpose is to help to reduce or eliminate harm to human health and the environment from releases of pollutants. [Note: Please see section 2.2 of this report "Superfund Amendments and Reauthorization Act" for information on EPCRA as required by E.O. 13148]. Agencies are also to advance the national policy that whenever feasible and cost effective, pollution should be prevented or reduced at the source. NETL has established the following targets:

- $\quad$ Reduce sanitary waste from routine operations by $30 \%$ by 2005 (6\% reduction annually), using a 1993 baseline. NETL is addressing this target using a variety of activities. Computer-based Training (CBT) is planned to increase employee awareness of NETL's requirements regarding sanitary waste generation. In addition, NETL plans to conduct a review of sanitary waste streams to characterize the wastes; emphasis will be placed on separating recyclables from the waste stream. NETL also proposes to assess cafeteria operations to determine if the use of disposable food containers and silverware could be minimized via a dishwasher to sanitize china plates and a stainless steel utensils. A reduction of approximately 18\% was accomplished from FY 2000 to FY 2001. 
- $\quad$ Recycle 35\% of sanitary wastes from all operations by 2005 (7\% annual recycling increase), using a 2001 baseline. This effort includes expanding the universe of recyclables to remove previously non-recycled items from the sanitary waste stream for reclassification as recyclable, and reviewing cafeteria operations and practices to determine what can be reused or composted on-site. An increase of approximately $19 \%$ of recycled sanitary waste was accomplished from FY 2000 to FY 2001.

- Segregate $75 \%$ of all construction and demolition wastes (e.g., concrete, wood, drywall, masonry, metal, asbestos, and lead) for recycling and/or disposal by 2005. NETL does not routinely generate this waste stream. As a result, it is often cost prohibitive to segregate this particular waste stream. However, a reasonable effort will be made to achieve this target. When projects of this type occur, a comprehensive sampling/analysis program will be followed to assure proper disposition of project-derived materials as hazardous or non-hazardous. All appropriate waste minimization/recycling procedures will be followed.

\section{Release Reduction: Toxic Chemicals} Innovative pollution prevention, effective facility management, and sound acquisition and procurement activities can help to reduce a facility's Toxic Release Inventory (TRI) releases, as well as the number of off-site transfers of toxic chemicals for treatment and disposal. DOE's goal is to reduce these numbers by $10 \%$ annually, or $40 \%$ by 2006 . Even though NETL does not have a "TRI inventory" to reduce, NETL has identified two specific significant environmental aspects that coincide with this goal: "Reducing Hazardous Material Procurement, Consumption, Storage and Release," and "Improving NETL's Chemical Handling Facility and its Operations."

- NETL's goal is to reduce hazardous material inventories/storage (by volume) by $20 \%$ by 2005 , based on a 2001 baseline. NETL plans to screen projects prior to startup to determine if non-TRI chemicals/reagents can be substituted for originally specified reagents. The existing on-site inventory will be screened to remove non-essential TRI chemicals.

- $\quad$ Perform facility and process fixes to chemical handling and dispensing facility/operations to lower risk levels by $\mathbf{2 0 0 5}$. Planned physical fixes to the Chemical Handling Facility including new roofs, installing new blow-out walls with windows, installing new HVACs, sealing the floor with an impervious material, installing garage doors and man doors, and purchasing specialized drums, racks, and shelving.

\section{Use Reduction: Toxic Chemical, Hazardous Substance, and Other Pollutants}

Identifying proven substitutes and establishing pollution prevention practices can help to reduce NETL's use of selected toxic chemicals, hazardous substances, and pollutants, or its generation of hazardous wastes. DOE's goal is a $40 \%$ reduction in hazardous wastes (e.g., laboratory chemicals, janitorial chemicals) by 2005, using a 1993 baseline. NETL has also identified a specific significant environmental aspect that coincides with this goal:"Improving NETL's Chemical Handling Facility and its Operations."

Reduce hazardous waste from routine operations $25 \%$ by 2005 , using a 1993 baseline. NETL plans to distribute a site-wide list of usable excess chemicals and equipment located at the NETL Chemical Handling Facility. This will allow researchers to search the site-wide stored chemicals database prior to purchasing new chemicals. There are also plans to institute use of a solvent recovery device to recover waste solvents for on-site use to minimize the amount of used solvent being disposed. 
Other plans include reactivating the Waste Minimization/Pollution Prevention Committee to review R\&D processes to the assess the potential to reduce chemical use and waste generation, reinstituting Pollution Prevention Opportunity Assessments for spot checks to determine potential for reducing/minimizing wastes, and reviewing hazardous wastes disposed by category and revisiting waste determination. Although NETL is well within meeting its 25\% reduction based on a 1993 baseline, there was an increase in hazardous waste generation from CY 2000 to CY 2001 caused by the extraordinary inclusion of lead contaminated demolition waste in the CY 2001 hazardous waste stream. The recyclable portion of the hazardous waste generated increased by $33 \%$ during this same time period.

\section{Reductions in Ozone-Depleting Substances}

By evaluating the present and future use of ozone-depleting substances and maximizing the purchase of and use of safe, cost-effective and environmentally preferable alternatives, facilities can develop a plan to phase out the procurement of Class I ozone-depleting substances. Based on DOE's goal of phasing out all nonexcepted uses of Class I ozone-depleting substances by 2010, NETL established the following targets:

- $\quad$ Retrofit or replace $100 \%$ of chillers greater than 150 tons of cooling capacity and manufactured before 1984 that use Class I refrigerants by 2005. NETL has two such chillers with a cooling capacity greater than 150 tons and a funding request in FY2001 was submitted to FEMP to replace these chillers. If FEMP approves this funding request, these chillers will be removed by FY2005. If FEMP does not approve NETL's funding request then funding will need to be secured from another source. Replacement of these chillers by 2005 will depend on availability of funding and budgetary restraints.

- $\quad$ Eliminate use of Class I ozone-depleting substances by 2010, to the extent economically practicable, and to the extent that safe alternative chemicals are available for DOE Class I applications. NETL plans to identify all Class I ozone-depleting substances by updating previous surveys, and then determining if an alternative to these substances is available. A plan will then be developed to eliminate all Class I ozone-depleting substances by 2010, to the extent economically practicable.

\section{Environmentally Beneficial Landscaping}

The order requires that agencies strive to promote the sustainable management of federal facility lands through the implementation of cost-effective, environmentally sound landscaping practices and programs to reduce adverse impacts to the natural environment. NETL has identified "Non-Industrial Land Use" as one of its significant environmental aspects; a corresponding Environmental Management Plan has been developed. A project team has been assembled to address the objective of conserving and enhancing non-industrial land by maintaining or increasing the percentage of land used for non-industrial purposes and increasing the quality of non-industrial land over time in terms of ecological benefit, utility, and diversity. The project team plans to conduct a feasibility study to identify and evaluate the best options for land use and improvement.

\subsubsection{E.O. 13101 --“Greening the Government through Waste Prevention, Recycling, and Federal Acquisition”}


Executive Order 13101, "Greening the Government through Waste Prevention, Recycling, and Federal Acquisition," was established to increase the federal government's use of recycled products and environmentally preferable products and services. The order requires purchasing EPA-designated items with recycled content to lessen the impact of virgin raw material use.

Increase purchases of EPA-designated items with recycled content to $100 \%$. A comprehensive directive on affirmative procurement with provisions for credit card compliance spot checks has been developed for all four sites. NETL plans to revise online versions of NETL-MGN and NIOSH-PGH storeroom catalogs so that both are in same format and are more user-friendly. Personnel are encouraged to obtain recycled content items from the warehouse rather than new items from offsite vendors. Computer-based training related to purchasing items of recycled content is being developed. In addition, NETL plans to review the purchase of disposable cafeteria items, substituting items manufactured with recycled materials where possible.

\subsection{3}

\section{E.O. 13123 "Greening the Government through Efficient Energy Management”}

Executive Order 13123, “ Greening the Government through Efficient Energy Management," focuses on improving energy management within the federal government to save taxpayer dollars and to reduce emissions that contribute to air pollution and global climate change. The federal government has the ability to lead the nation in energy efficient building design, construction and operation, as well as promoting energy efficiency, water conservation, and the use of renewable energy products. Based on DOE's Energy Efficiency Goals, NETL established the following targets:

- $\quad$ Reduce greenhouse gas emissions attributed to facility energy use through life-cycle cost-effective measures by $25 \%$ by 2005 and $30 \%$ by 2010 , using 1990 as a baseline. Based on an energy management performance agreement NETL has with the Office of Energy Efficiency and the Office of Fossil Energy, the following performance objectives have been implemented: (1) establish an energy management plan; (2) meet the FY2005 energy reduction goal of 30\% per square foot from the 1985 level; (3) conduct comprehensive energy audits of the facilities; (4) complete cost-effective projects identified by the comprehensive energy audits; (5) meet or exceed Federal energy efficiency standards for new building construction; (6) identify no cost/low cost utility conservation and efficiency improvement opportunities and capture cost savings; and (7) purchase energy and water efficient products. These performance objectives provide the guidance for NETL to achieve the energy usage reductions by 2005 and 2010.

- $\quad$ Reduce energy consumption through life-cycle cost effective measures by:

- $\quad 30 \%$ by 2005 per gross square foot for buildings, using a 1985 baseline (see above)

- $\quad 20 \%$ by 2005 and $30 \%$ by 2010 per gross square foot, or per other unit as applicable, for laboratory and industrial facilities, using a 1990 baseline. Based on an energy management performance agreement NETL has with the Office of 
Energy Efficiency and the Office of Fossil Energy, the following performance objectives have been implemented: (1) establish an energy management plan; (2) meet the FY2005 energy reduction goal of $30 \%$ per square foot from the 1985 level; (3) conduct comprehensive energy audits of the facilities; (4) complete cost-effective projects identified by the comprehensive energy audits; (5) meet or exceed Federal energy efficiency standards for new buildings; (6) identify no cost/low cost utility conservation and efficiency improvement opportunities and capture cost savings; and (7) purchase energy and water efficient products.

- $\quad$ Increase the purchase of electricity from renewable energy sources by including provisions for such purchase as a component of our request for bids in $100 \%$ of all future DOE competitive solicitations for electricity. NETL plans to evaluate the purchase of electricity from renewable energy sources as a component of request for bids in future NETL electric power supply competitive solicitations. Determining factors include: (1) availability of a reliable consistent volume of clean renewable energy in the Eastern Ohio, Southwestern Pennsylvania, Northern West Virginia and Northwestern Maryland grid areas; (2) the wheeling price or fee charges/transmission connection of the renewable energy supply for NETL; (3) the potential impact of electric utility deregulation in West Virginia. Purchase of renewable energy generation sources will depend on appropriate funding levels since this type of electrical power is historically more expensive. NETL will include provisions for purchase of electricity from renewable sources in all future DOE competitive solicitations.

- Increase the purchase of electricity from less greenhouse gas-intensive sources, including but not limited to new advanced technology fossil energy systems and other highly efficient generating technologies. NETL's electrical energy supplier, Allegheny Energy Supply, identifies that of its current $8813 \mathrm{MW}$ of generation, $48 \%$ is produced by less greenhouse gas intensive sources. This $48 \%$ includes $0.66 \%$ hydroelectric, $2.5 \%$ natural gas generation and $45 \%$ coal-fired power plants with scrubbers to control $\mathrm{SO}_{\mathrm{x}}$ and $\mathrm{NO}_{\mathrm{x}}$ emissions. NETL plans to evaluate various energy suppliers within its grid and use the factors identified in Section 8 a to select cost-effective suppliers for purchasing electrical power from these sources. Purchase of less greenhouse gas-intensive generation sources will depend on appropriate funding levels since this type of electrical power is historically more expensive.

- $\quad$ Reduce NETL's entire fleet's annual petroleum consumption by at least $20 \%$ by 2005 in comparison to 1999 (23,400 gallons), including improving the fuel economy of new light duty vehicle acquisitions, and by other means. In FY2001 approximately $71 \%$ of NETL's fleet is alternative fuel vehicles. NETL expects to have more than $75 \%$ of its fleet in FY2002 as alternative fueled vehicles. NETL has requested funds to install two quick-fill CNG refueling stations and also install two 1000 gallon tanks for ethanol. If NETL receives the funding for these installations then it will be able to reduce the entire fleet's annual petroleum consumption by at least $20 \%$ by 2005 . If NETL does not receive the necessary funding, the infrastructure to support refueling with alternative fuels is limited and the $20 \%$ reduction will not be realized. 
- Acquire each year at least $75 \%$ of light duty vehicles as alternative fuel vehicles, in accordance with the requirements of the Energy Policy Act of 1992. NETL currently is acquiring about $95 \%$ of its light duty vehicles as alternative fuel vehicles and plans to continue this practice as long as GSA can supply these vehicles.

- Increase the usage rate of alternative fuel in Departmental alternative fuel vehicles to $75 \%$ by 2005 and $90 \%$ by 2010 in areas where alternative fuel infrastructure is available. NETL has requested funds to install two quick-fill CNG refueling stations and also install two 1000 gallon tanks for ethanol. If NETL receives the funding for these installations then it will be able to increase the usage rate of alternative fuel in Departmental alternative fuel vehicles to $75 \%$ by 2005 and $90 \%$ by 2010 . If NETL does not receive the necessary funding for the installations, the infrastructure to support refueling with alternative fuels is limited and the $75 \%$ and $90 \%$ usage rates will not be realized.

\subsubsection{E.O. 11988 "Floodplain Management"}

Floodplain management is not applicable. The NETL sites did not conduct any actions impacting floodplain management in 2001.

\subsubsection{E.O. 11990 "Protection of Wetlands"}

Protection of Wetlands is not applicable. The NETL sites did not conduct any actions impacting wetlands in 2001. 


\section{Environmental Program Information}

\subsection{Introduction}

The following is a brief description of the major environmental programs at NETL, including site meteorology, monitoring and surveillance, environmental restoration and waste management, and effluent monitoring.

Additionally, information on significant environmental activities at NETL not adequately covered in other sections is presented here. This includes the site's environmental management system (EMS), directives program, environmental occurrences, facility environmental performance measures, environmental training programs, pollution prevention and waste minimization programs and DOE's (Secretarial) Pollution Prevention and Energy Efficiency Goals (November 1999). There is also a discussion of NETL's initiatives pursuant to the President's Clean Water Action Plan, including efforts to improve water quality through collaborative approaches to watershed protection administered through the States, local governments, industry, other federal agencies, and interested stakeholders. Information presented in the Compliance Summary and other sections of this report are not discussed here.

\subsection{Site Meteorology}

Meteorological data for the MGN was collected via a 150-foot free-standing meteorological tower. Data collection points are at ground level, and above ground at 33 feet, 75 feet, and at 150 feet. The data collected at ground level was air temperature, relative humidity, and total rainfall. The other stations monitor wind direction, wind speed, and air temperature. All data collected is stored on a computer, located in Building 33 of the Morgantown site.

Meteorological data for the Pittsburgh site was collected via three separate 33-foot free-standing meteorological towers. Data collection points were at ground level, and above ground at 6 feet and 33 feet. The data collected at ground level was rainfall. Relative humidity, air temperature and solar radiation were collected at the 6-foot levels. Air temperature, vertical and horizontal wind speed, and wind direction were collected at the 33-foot increment. Data collected is stored on computers, located in PGH's Building 922 and $\mathrm{PM}_{2.5}$ trailer.

Meteorological data at the Morgantown and Pittsburgh sites was used in modeling for emissions and emergency response. Data was also used in a project management Power and Environmental Systems experimental $\mathrm{PM}_{2.5}$ study.

\subsection{Site Monitoring and Surveillance}

NETL currently monitors groundwater, stormwater, industrial wastewater, drinking water, meteorological conditions, and air emissions (based on the scope and nature of individual research 
projects) independently at the on-site research sites in accordance with regulatory requirements and NETL Operating Plan 450.1-1A, "NETL Environmental Media and Release Management". Limited analyses with regard to Total Petroleum Hydrocarbons (TPH) from several designated groundwater monitoring wells at Pittsburgh were supplied to the State of Pennsylvania as requested in conjunction with remedial actions for the removal or abandonment in place of several underground storage tanks during August of 1994. The results were requested by the State and were not provided as the result of any consent agreement or permit requirement. A detailed discussion of groundwater monitoring is presented in Section 7. All records pertaining to site monitoring and surveillance are maintained in a centralized records management system.

Storm water discharges at NETL facilities are monitored under guidance from the West Virginia Division of Environmental Protection and the Pennsylvania Department of Environmental Protection through the NPDES permitting program. Stormwater is monitored in accordance with federal and state regulations, permit requirements, and NETL Procedure 450.1-3A, "NETL Surface Water Quality Management," for parameters established by the respective states based on historical data. Discharge monitoring reports are submitted annually at Morgantown and quarterly at Pittsburgh in accordance with permit requirements. As a permitted entity, NETL has prepared a Stormwater Pollution and Prevention Plan (SWPPP) in accordance with state and federal guidelines for preparing Pollution Prevention Plans. The SWPPP is updated annually and controlled copies are maintained at the Morgantown and Pittsburgh sites.

Industrial wastewater discharges at NETL facilities are monitored under guidance from the Morgantown Utility Board (MUB) and the Pleasant Hills Authority (PHA) through the NPDES Pretreatment Program. Industrial wastewater is monitored in accordance with federal, state, and local regulations, pretreatment permit requirements, and NETL Procedure 450.1-4A, "NETL Industrial Wastewater Management," for parameters specified by the governing regulatory authority. Discharge monitoring reports are submitted monthly at Morgantown and semiannually at Pittsburgh in accordance with pretreatment permit requirements. The Pleasant Hills Authority has also requested that the effluent from Pittsburgh's Waste Water Treatment Facility be monitored and reported on a monthly basis, however, this is not pursuant to any consent agreement or permit requirement. NETL industrial wastewater pretreatment systems are operated in accordance with approved standard operating procedures and NETL environmental, safety, and health policies.

Although not required, NETL monitors drinking water under the auspices of the Safe Drinking Water Act (SDWA). Since NETL does not own or operate a public water system, regulation under the Safe Drinking Water Act does not apply, however, the Morgantown and Pittsburgh sites periodically monitor drinking water at selected locations and compare the results to the primary and secondary drinking water standards delineated under the Act as a best management practice. None of the monitoring results would have violated the primary or secondary drinking water standards during 2001. All monitoring results are maintained in the centralized records management system. The most recent results for each sampling location are posted and maintained at that location as public information.

Compliance with applicable ambient air quality requirements at NETL facilities is maintained in accordance with federal, state, and local regulations and NETL Procedure 450.1-1, "NETL Ambient Air Quality Management." Air emission estimates are generated and maintained for all projects and operations at the Morgantown and Pittsburgh sites. An annual Air Emissions Inventory is prepared for 
each site and submitted to the governing regulatory agency as required. The emissions estimated for the Morgantown and Pittsburgh sites indicated no significant changes in status from the previous year. The Certificate to Operate Morgantown's Synthetic Gas (SynGas) Generator/Hot Gas Desulfurization (HGD) Process Development Unit (PDU), issued through the West Virginia Division of Environmental Protection, Office of Air Quality, was maintained. Compliance with the CAA (Clean Air Act) Title V exemption was maintained through the summary of collected air emission estimates from all processes and projects on each site.

Meteorological conditions are monitored at the Morgantown and Pittsburgh sites in accordance with NETL Procedure 450.1-1, "NETL Ambient Air Quality Management," through the collection of "realtime" data obtained by means of free-standing meteorological monitoring towers and associated sensors and instrumentation. Air temperature, relative humidity, rainfall, wind direction, wind speed, and solar radiation are measured and archived on electronic media. The data is readily available for various uses including project operations and planning, air dispersion modeling, and emergency response efforts if necessary.

\subsection{Effluent Monitoring}

The Pittsburgh and Morgantown sites monitored their surface water discharges consisting of industrial wastewater effluent from the clarifier in Morgantown, industrial wastewater effluent from Pittsburgh's wastewater treatment facility, and stormwater discharge from the Morgantown and Pittsburgh sites.

Surface water effluent from the 69-acre Pittsburgh site discharges into Lick Run - a small natural stream that flows along the eastern boundary of the 238-acre, three agency Bruceton Research Center. Contributions to the Pittsburgh stormwater effluent are regulated by a National Pollutant Discharge Elimination System (NPDES) stormwater discharge permit and consist of air conditioning condensate, runoff from various impervious surfaces into the site storm sewer, and treated acid mine drainage from a safety research coal mine operated by NIOSH. Monitoring results can be found in Table 7. (Tables 7 to 24 can be found in the appendix.)

Surface water effluent from the 132-acre Morgantown site discharges into Burroughs Run and West Run, tributaries of the Monongahela River. Effluent is composed only of storm water runoff from buildings, parking lots, developed and undeveloped areas. Three outfalls are required to be monitored by the NPDES stormwater discharge permit. Monitoring results can be found in Table 7.

The Morgantown site monitored its industrial wastewater effluent according to a permit issued by the Morgantown Utility Board. Industrial wastewater included non-contact cooling water, non-contact process cooling water overflow, boiler blowdown, laboratory sink, laboratory floor drains, and motor pool wastewater. Monitoring results can be found in Table 8. The Pittsburgh site monitored its industrial wastewater according to a permit issued by the Pleasant Hills Authority. Monitoring results can be found in Table 9. 


\subsection{Other Environmental Issues and Actions}

\subsubsection{Directives Program}

The directives process used total quality management principles to identify and implement standards that adequately protect workers, the public, and the environment. The starting point was a clear plan for the work to be performed (such as construction, operation, research, or remediation). A team analyzed the work plan to determine potential hazards and identify ways to remove or control those hazards. In addition to this team's analysis, input and suggestions were sought from stakeholders, including members of the public, employees, and union representatives regarding concerns or hazards that must be addressed and approached for ensuring adequate environmental protection. The primary objective of the process was to identify or develop a set of directives that, when implemented, provides reasonable assurance that the health and safety of the workers, public, and the environment will be protected during the performance of the work.

In 1996, NETL identified hazards at the Pittsburgh and Morgantown sites through distribution of standard forms listing a wide range of possible hazards. Each division or operation was asked to identify possible hazards in their workplace, and to return the completed forms. The results were used to establish control requirements for all waste activities.

In 2001, the risks associated with the hazard identification process were addressed through the development and implementation of a comprehensive set of environment, safety, and health (ES\&H) directives at NETL. Although this process is not expected to be completed until 2003, final directives for ISM, ES\&H reporting, ES\&H requirements for offsite contractors, R\&D SARS, life safety design criteria, work control, and Environmental Management (ISO 14001) were completed during 2000/2001. The development of many other directives was initiated and reviewed during 2001, a complete cycle from inception to final approval that often takes over a year to complete. Directives receive a rigorous internal review by all internal stakeholders prior to final approval by senior management. Directives will be reviewed each year for the first 3 years and then every three years thereafter. Reviews can occur more frequently if a change in regulations or site conditions occurs. Official copies of the directives are accessible through the NETL internal intranet web site.

All environmental, safety, and health directives (these are procedures that detail site program requirements including responsibilities) and EMS (ISO - Environmental Management System) documentation may be accessed via the NETL Internal Intranet web site. Copies of directives that are not accessed on the Intranet in real-time are considered uncontrolled documentation, as the only means to ensure the use of the most current copy is to view it electronically. NETL employees are trained and aware of this practice. Order 450.1A is the EMS directive outlining NETL environmental policy. A separate procedure (P450.1-6) was prepared to outline the process for identifying and maintaining environmental aspects, objectives and targets, and environmental management plans (these discuss how the objectives/targets will be accomplished by operational controls, etc.). These are tracked on both a quarterly and an annual basis. Employees are made aware of the importance of conformance with the environmental policy and procedures and the requirements of the environmental management system 
through the internal intranet web site, site posters, and PRISM badges (contains the environmental policy

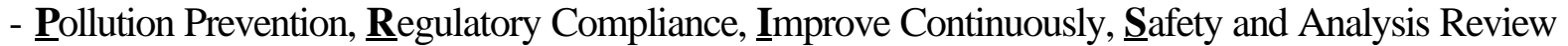
Systems, Minimize Waste).

The significant environmental impacts of employee work activities and the environmental benefits of improved personal performance are communicated through the NETL Intranet web page, computer based training (and lecture based), and quarterly EMS audits (the auditee is asked which environmental aspects are affected by their daily activities, and what are the aspects that have been identified for NETL). Employees are also required to know their roles and responsibilities in achieving conformance with the environmental policy, site procedures and with requirements of the environmental management system, including emergency preparedness and response requirements. During audits employees are asked to respond to questions concerning the consequences of their non conformance with site policy and procedures (as applies to environmental aspects). In 2002 quarterly audits will continue and further screening will be implemented to collect project information relevant to ISO 14001.

\subsubsection{Environmental Occurrences}

Notification of environmental occurrences is required under a number of Federal, state, and local environmental statutes and regulations, and DOE. NETL Procedure 151.1-2, Occurrence Categorization and Reporting, implements these DOE reporting requirements and complies with state and local statutes.

DOE Order 232.1A provides guidelines on categorizing and reporting environmental occurrences to DOE. The order divides occurrences into three categories: emergencies, unusual occurrences, and off-normal occurrences. At the Morgantown and Pittsburgh sites, an onsite emergency response organization (ERO) is in place and responds 24-hours a day. The ERO cleans up or mitigates small spills. If larger spills occur, offsite assistance is used as needed. Once an incident occurs, the ERO is responsible for categorizing the incident, notifying the proper regulatory agencies, and completing the DOE occurrence reporting.

NETL reported three occurrences during 2001. All three occurrences were environmental in nature. See section 2.4 "Clean Water Act and National Pollution Discharge Elimination Program."

A NOV from the Pleasant Hills Authority (Pennsylvania) for exceeding wastewater discharge limits was received on January 8, 2001. The NOV alleged that NETL exceeded the allowable discharge concentrations of free cyanide into the sanitary sewer system on October 26, 2000. The discharge from this wastewater is covered by the NETL Industrial Sewer Use Permit at the sanitary sewer subinterceptor location. The non-compliance issue, which included recognition by the Pleasant Hills Authority that NETL was not the source of contamination at this sampling location, was resolved. NETL is no longer required to sample at this location.

A water quality violation took place on January 30, 2001. On April 23, 2001 Pleasant Hills Authority issued NETL a NOV based on findings made on the quality of the wastewater discharge. The discharge limits are established in Section V - Discharge Permit Requirements of the Industrial Sewer Use Permit. 
The NOV noted that NETL had failed to meet local limits for wastewater discharge for Mercury. Analysis of the WWTF treated effluent sample indicated a mercury concentration of $0.0003 \mathrm{mg} / \mathrm{L}$, which exceeds the allowable discharge limit of $<0.0002 \mathrm{mg} / \mathrm{L}$. To mitigate further occurrences, NETL completed several modifications aimed at improving the quality of the wastewater discharge.

A wastewater discharge incident occurred on March 27, 2001. On May 22, 2001 Pleasant Hills Authority issued NETL a Notice of Enforcement Action Letter of Violation (NOV) based on findings made on the quality of the wastewater discharge. The discharge limits are established in Section V Discharge Permit Requirements of the Industrial Sewer Use Permit. The NOV noted that NETL had failed to meet local limits for wastewater discharge on $\mathrm{pH}$. Analysis of the WWTF treated effluent sample indicated a $\mathrm{pH}$ concentration of 9.1, which exceeds the allowable discharge limit of 9.0. NETL has performed several modifications to the WWTF aimed at improving the quality of the wastewater discharge.

\subsubsection{Environmental Performance Measures}

Throughout 2001, a formalized approach to performance measurement was employed as part of an effort to address performance requirements, such as those mandated by the Government Performance and Results Act. This approach included measurement elements covering management of ES\&H risks associated with implementing organizational missions. Goals and objectives for ES\&H activities were established and specific performance targets addressing ES\&H risks were included for measurement. Refinements of ES\&H strategies and specific targets to meet the goals and objectives for 2001 were made, based on performance results from 2000 and changing organizational initiatives.

On November 21, 2000, NETL management established a set of top-level performance measures to manage NETL's ES\&H risk effectively and efficiently. The vision of these measures is to be recognized as providing value-added ES\&H consultation and management services and support to internal and external stakeholders.

Environmental performance measures at NETL included (1) tracking the number of environmental occurrences (such as permit exclusions), (2) the amount of hazardous wastes being generated, and (3) the successful implementation of activities required to attain ISO 14001 certification. Generally speaking, performance improved for NETL in 2001 when compared to previous years.

\subsubsection{Environmental Training Programs}

NETL provided several environmental training programs during 2001. A new Computer Based Training (CBT) course on Environmental Management Systems (EMS) was developed and deployed for all employees of NETL to support the ISO 14001 effort. This course provided knowledge of how NETL manages environmental systems by establishing policy, procedures and a management structure to support the effort. The training emphasized the importance of compliance with the EMS and the potential for adverse consequences from departures from the procedures including operating procedures. The roles and responsibilities of everyone in achieving success in the EMS and the benefits of that effort were detailed. This course was required for all NETL employees. 
Ongoing training included providing training designed to meet regulatory requirements such as Hazardous Waste Operations and Emergency Response (HAZWOPER) and Hazardous Waste Handlers. Environmental training continued to be provided for new or reassigned personnel in RCRA hazardous waste for lab and project workers, in Integrated Safety Management (ISM) for all new employees, and Contracting Officer Representatives (COR) ISM for all new Contracting Officer Representatives. The ISM courses provide knowledge of how Environmental, Safety and Health are integrated under the ISM umbrella and raise awareness of the environmental requirements for our work, both onsite and offsite.

In addition to the training needs identified by the NETL ES\&H Training System and the ES\&H Program Managers, several training needs were identified by an internal ISO 14001 Audit. One need was that a system did not exist to show that operational training needs were satisfied for employees. The other area identified that additional information on Environmental Management and ISO 14001 was needed to achieve the desired employee knowledge levels. Preliminary work was performed during 2001 to fill those needs identified by the audit.

\subsubsection{Pollution Prevention and Waste Minimization Program}

Recycling of wastes (or prevention of generation) is an integral part of the NETL pollution prevention/waste minimization program.

NETL-Pittsburgh is mandated to recycle by the State of Pennsylvania under Pennsylvania Act 101Municipal Waste Planning, Recycling, and Waste Reduction Act. The Morgantown site is not required to recycle by West Virginia State regulations, but is required to comply with federal executive orders.

All four sites maintained recycling programs, and the following inherently non-hazardous items were recycled whenever possible: office wastes (mixed paper, newspapers, magazines, and toner cartridges), scrap metal, aluminum beverage containers, corrugated cardboard, and telephone books . In addition, used motor oil was recycled offsite for re-refining and subsequent re-use. Some process solvents were placed into fuels blending programs for beneficial re-use as fuels. Batteries (lead-acid, dry-type, other) are sent to the appropriate recycling facility by the NETL hazardous waste disposal contractor. Vehicle tires were sent offsite for use as fuel or for use in a shredded rubber re-use process. Wooden pallets are placed into the recycle stream for re-use as pallets or landscape mulch.

Toner cartridges are sent offsite to a vendor who refills them and returns them to NETL. The cartridges are kept out of the waste stream and the cost for refilling is lower than the cost for new replacements. This procedure not only saves money but helps NETL meet affirmative procurement requirements.

In addition, process-related or -derived materials (both raw materials and non-hazardous waste products) such as unused waste coal or process-generated fly ash were, whenever possible, reclaimed for beneficial use as raw materials useable in an offsite process (e.g., boiler fuel or cement, respectively).

\subsubsection{Clean Water Action Plan}


The Clean Water Action Plan is not applicable to NETL. The NETL sites did not conduct any actions impacting watersheds with critical water quality problems in 2001. 


\section{Environmental Management Information}

The NETL sites are staffed by ES\&H professionals who reviewed activities to assure that the sites comply with environmental laws and regulations. All onsite research projects and support activities were reviewed by ES\&H staff, in conjunction with the safety analysis and review system (SARS), for possible impacts on air, surface water, groundwater, and soil. Applicable federal, state, and local regulations potentially affecting these activities are reviewed and compliance assured before approval by the ES\&H staffs.

\subsection{Integrated Management Activities}

Since 1996 the primary DOE Safety Management System has been the Integrated Safety Management System (ISMS). The objective of ISMS is to systematically integrate ES\&H requirements and work practices into all planning and execution accomplished by DOE and its contractors. NETL has embraced and implemented ISMS, but recognizes that continuous improvement is an important part of ISMS. As part of the continuous improvement process for ISMS NETL has chosen to pursue ISO 14001 certification for further integrating of the environmental management systems (EMS) into ISMS.

Other ISMS continuous improvements activities included continuing to integrate ES\&H directives from the two locations into unified NETL directives. Improvement activities based on the opportunities for improvement from the ISMS Verification Review continued during 2001 including work related to items such as project specific training identification, operator qualifications, and near misses. Several of the site support contractors including EG\&G, D. N. America, and KRay revised their ISM Plans during 2001.

In December 2001 the NETL Director and Deputy Director for Operations attended the Executive Safety Conference in Washington, DC, which was titled "Taking Integrated Safety Management (ISM) to the Next Level". Undersecretaries Robert Card and General John Gordon encouraged attendees to pursue full implementation of ISM and achieve excellence in ES\&H management throughout the DOE complex. This conference clearly underscored DOE's continuing commitment to ISM. 


\section{Environmental Radiological Program Information}

The Atomic Energy Act (AEA) of 1954, and its amendments, are the Federal laws that mandate DOE control radioactive materials in order to protect public safety and health. DOE orders, the EPA, and Nuclear Regulatory Commission (NRC) regulations are based on the AEA. Under the amended AEA, DOE is responsible for establishing and maintaining an environmental, health, and safety protection program. Furthermore, although DOE facilities are generally exempt from NRC regulations, the facilities are to meet the intent of these regulations.

NETL does not generate, transport, process, treat, or have onsite permanent disposal of any radioactive waste. However, NETL used, in the conduct of research, instrumentation that contained radioactive sources. Also, four phosphorescent exit signs were used in the Morgantown site's hazardous waste facility. An inventory of radiation sources was maintained by the radiation safety officer, indicating the item, isotope, quantity, custodian, location, status, and activity. Table 6 lists the 2001 source inventory. NETL did not release any radionuclides into the environment, as all of its sources are sealed and are used in instrumentation.

The radiation monitoring performed at NETL consisted of a limited number (less than 20) of personal dosimeter badges and rings supplied under a contract with Siemens Gammasonics, Inc. In addition, leak testing was conducted on all applicable sealed sources with analysis also performed by Siemens Gammasonics, Inc. for NETL-Morgantown. Leak testing is conducted on all applicable sealed sources at Pittsburgh by Applied Health Physics. 
Table 6. NETL Radioactive Materials Inventory for 2001

\begin{tabular}{|c|c|c|c|c|}
\hline Isotope & Quantity & Activity & Supplier/Source & Location \\
\hline $\mathrm{Kr}-85$ & 1 & $2 \mathrm{mCi}$ & $\begin{array}{l}\text { Model No. } 3077 \\
\text { Serial No. } 700 \mathrm{~T} \\
\text { Thermo-Systems, Inc. }\end{array}$ & MGN \\
\hline $\mathrm{Kr}-85$ & 1 & $2 \mathrm{mCi}$ & $\begin{array}{l}\text { Model No. } 3012 \\
\text { Serial No. } 467 T \\
\text { Thermo-Systems, Inc. }\end{array}$ & MGN \\
\hline $\mathrm{Kr}-85$ & 1 & $2 \mathrm{mCi}$ & $\begin{array}{l}\text { Model No. } 3012 \\
\text { Serial No. 626T } \\
\text { Thermo-Systems, Inc. }\end{array}$ & MGN \\
\hline $\mathrm{Kr}-85$ & 1 & $2 \mathrm{mCi}$ & $\begin{array}{l}\text { Model No. } 3077 \\
\text { Serial No. 373T } \\
\text { Thermo-Systems, Inc. }\end{array}$ & MGN \\
\hline $\mathrm{Kr}-85$ & 1 & $2 \mathrm{mCi}$ & $\begin{array}{l}\text { Model No. } 3077 \\
\text { Serial No. } 697 \mathrm{~T} \\
\text { Thermo-Systems, Inc. }\end{array}$ & MGN \\
\hline $\mathrm{Ni}-63$ & 1 & $15 \mathrm{mCi}$ & $\begin{array}{l}\text { Model No. } 6000204 \\
\text { Serial No. } 533 \\
\text { Perkin-Elmer Corporation }\end{array}$ & MGN \\
\hline Sc-46 & 1 & $0.065 \mathrm{mCi}$ & $\begin{array}{l}\text { University of Missouri } \\
{ }^{*} \text { Source encapsulated by a } \\
\text { nylon bead. }\end{array}$ & MGN \\
\hline Sc-46 & 1 & $0.046 \mathrm{mCi}$ & $\begin{array}{l}\text { University of Missouri } \\
{ }^{*} \text { Source encapsulated by a } \\
\text { nylon bead. }\end{array}$ & MGN \\
\hline Ra-226 & 1 & $9 \mu \mathrm{Ci}$ & $\begin{array}{l}\text { Model No. B-5 } \\
\text { Serial No. } 11205 \\
\text { Mettler Corporation }\end{array}$ & MGN \\
\hline Ra-226 & 1 & $21 \mu \mathrm{Ci}$ & $\begin{array}{l}\text { Model No. }-5 \\
\text { Serial No. } 17032 \\
\text { Mettler Corporation }\end{array}$ & MGN \\
\hline Phosphate Rock & 1 & $\begin{array}{l}\text { Consumer } \\
\text { Product }\end{array}$ & $\begin{array}{l}\text { Model No. } 1080 \\
\text { Sun Nuclear Corporation }\end{array}$ & MGN \\
\hline Ra-226 & 1 & $9 \mu \mathrm{Ci}$ & $\begin{array}{l}\text { Model No. B-5 } \\
\text { Serial No. } 13805 \\
\text { Mettler Corporation }\end{array}$ & MGN \\
\hline $\mathrm{H}-3$ & 1 & $20 \mathrm{Ci}$ & $\begin{array}{l}\text { Model No. B100/U10 } \\
\text { Serial No. } 575263 \\
\text { SRB Technologies }\end{array}$ & MGN \\
\hline $\mathrm{H}-3$ & 1 & $20 \mathrm{Ci}$ & $\begin{array}{l}\text { Model No. B100/U10 } \\
\text { Serial No. } 574434 \\
\text { SRB Technologies }\end{array}$ & MGN \\
\hline
\end{tabular}


Table 6. NETL Radioactive Materials Inventory for 2001 (continued)

\begin{tabular}{|c|c|c|c|c|}
\hline Isotope & Quantity & Activity & Supplier/Source & Location \\
\hline $\mathrm{H}-3$ & 1 & $20 \mathrm{Ci}$ & $\begin{array}{l}\text { Model No. B100/U10 } \\
\text { Serial No. } 574435 \\
\text { SRB Technologies }\end{array}$ & MGN \\
\hline $\mathrm{H}-3$ & 1 & $20 \mathrm{Ci}$ & $\begin{array}{l}\text { Model No. B100/U10 } \\
\text { Serial No. } 574436 \\
\text { SRB Technologies }\end{array}$ & MGN \\
\hline Co-57 & 1 & $12 \mathrm{mCi}$ & $\begin{array}{l}\text { Model No. IPL CUS } \\
\text { Serial No. EE661 } \\
\text { Isotope Products Lab }\end{array}$ & MGN \\
\hline Cs-137 & 1 & $1 \mu \mathrm{Ci}$ & Tele-Atomic, Inc. & MGN \\
\hline Cs-137 & 1 & $10 \mu \mathrm{Ci}$ & Tele-Atomic, Inc. & MGN \\
\hline Ba-133 & 1 & $1 \mu \mathrm{Ci}$ & Tele-Atomic, Inc. & MGN \\
\hline Ba-133 & 1 & $10 \mu \mathrm{Ci}$ & Tele-Atomic, Inc. & MGN \\
\hline TI-204 & 1 & $1 \mu \mathrm{Ci}$ & Tele-Atomic, Inc. & MGN \\
\hline TI-204 & 1 & $10 \mu \mathrm{Ci}$ & Tele-Atomic, Inc. & MGN \\
\hline Po-210 & 4 & $\begin{array}{c}\text { Consumer } \\
\text { Product }\end{array}$ & Anti-Static Brushes & PGH \\
\hline Cs-137 & 3 & $\begin{array}{l}40 \mathrm{mCi}(2) \\
20 \mathrm{mCi}(1)\end{array}$ & $\begin{array}{l}\text { Ronan Engineering Company, } \\
\text { Model } 137 \\
\text { Level Density Gauge }\end{array}$ & PGH \\
\hline Cs-137 & 4 & $\begin{array}{c}30 \mathrm{mCi}(3) \\
6 \mathrm{mCi}(1)\end{array}$ & $\begin{array}{l}\text { Berthold Systems, Inc. Model } \\
\text { LB-7400D } \\
\text { Level Density Gauges }\end{array}$ & PGH \\
\hline Assorted & 80 & $\begin{array}{c}\text { Consumer } \\
\text { Product }\end{array}$ & Smoke Detectors & PGH \\
\hline $\mathrm{Ni}-63$ & 1 & $15 \mathrm{mCi}$ & $\begin{array}{l}\text { Gas Chromatograph Electron } \\
\text { Capture Device }\end{array}$ & PGH \\
\hline
\end{tabular}




\section{Environmental Non-Radiological Program Information}

The nonradiological monitoring program at NETL was designed to meet permit requirements and to assess the effectiveness of ongoing waste minimization and pollution prevention programs. The 2001 monitoring program focused on industrial wastewater, stormwater, groundwater, hazardous waste, and soil. The NETL sites are not required and did not perform air emissions monitoring because NETL has received a Title $\mathrm{V}$ exemption. In order to maintain this exemption, the hours of operation for the Morgantown PDU are maintained. Specific monitoring and permit information is in Section 2.4 of this report.

\subsection{Clarifier Effluent Monitoring}

The Morgantown site was permitted by MUB to connect to the city's POTW and was required by that permit to conduct monthly monitoring of the clarifier effluent. The wastewater was treated to adjust the $\mathrm{pH}$, if necessary to meet the permit limitation. Clarifier effluent monitoring parameters and the sampling results are presented in the appendix.

The Pittsburgh site's effluent water consisted of a pre-treated industrial wastewater component combined with the sanitary wastewater stream. The primary objective of the industrial wastewater monitoring program was to comply with the Pleasant Hills, Pennsylvania, POTW pretreatment requirements. Table 8 in the appendix contains industrial wastewater effluent data for the NETL sites.

\subsection{Stormwater Monitoring}

The primary objectives of the stormwater discharge monitoring program are to comply with a multiple federal party ( Dept. Of Energy-NETL, National Institute for Occupational Safety and Health NIOSH, and Mine Safety and Health Administration - MSHA) National Pollutant Discharge Elimination System (NPDES) stormwater discharge permit at the Pittsburgh site, and a general storm water discharge permit at the Morgantown site. Pittsburgh's NPDES permit requires both quarterly (outfalls 001 and 002 - reported quarterly) and weekly sampling and reporting (outfall 101 - treated acid mine water, sampled weekly, reported monthly). Semiannual samples were taken at the Morgantown site. Pittsburgh storm water flows to Lick Run and ultimately to the Monongahela River. Morgantown storm water flows to Burroughs Run and West Run, and ultimately to the Monongahela River. Table 7 contains monitoring data related to stormwater discharges for NETL's sites.

Laboratory and process wastewater generated at the Pittsburgh site are pretreated in the site Wastewater Treatment Facility (WWTF) for removal of metals and organics prior to discharge into the 
sanitary sewer (under the auspices of the site's Industrial Sewer Use Permit). Prior to construction of the WWTF in 1985, these wastewater streams were discharged into the sanitary sewer or Lick Run. A separate collection sewer system was designed and built as part of the WWTF construction program. An extensive drainage system survey and re-routing effort took place to assure that all facility drainage systems carrying non-sanitary (domestic) sewage were re-routed into the WWTF collection sewer. Subsequently, dye testing was performed on drains whose routing was unknown or suspect and appropriate corrective actions (re-routing or plugging) were taken where incorrectly routed drains were discovered. Dye testing was also performed on new construction to confirm that new drains were properly routed.

\subsection{Waste Minimization}

NETL hazardous waste generation rates for the past 7.5 years have been, for the most part, significantly lower than the rates of prior years. The decrease is partially reflective of several waste minimization efforts and initiatives instituted over that time period. However, quarterly hazardous waste generation rates at NETL-Morgantown have historically exhibited wide variations since they are dependent upon many complex factors. These factors include, but are not limited to, project schedules and operational activities, facility management and maintenance activities, responses to various audits or assessments (e.g., corrective action plan response to the tiger team assessment), the R\&D nature of the facility, and significant management initiatives.

Monitoring the generation of solid, low-level radioactive, hazardous, and mixed waste, allowed NETL to assess the effectiveness of its waste minimization program. Reducing or minimizing the waste generated decreased waste management needs (e.g., on-site housing, transportation, and disposal needs), thereby reducing the cost, environmental impact, and liability of such operations.

Employees are required to determine the feasibility of utilizing less hazardous reagents in their research wherever feasible. In addition, employees are required to obtain chemicals from the site's inventory where possible. If existing inventory is not sufficient, purchase of new chemicals in the smallest amounts possible is encouraged to minimize waste disposal and/or storage requirements.

The site waste disposal contractor is required to find outsources for recycling wastes where the technology is available rather than to dispose of these wastes.

At the Pittsburgh site, waste inorganic laboratory acids and caustics (uncontaminated by other hazardous substances) are neutralized in the site wastewater treatment facility - a practice permitted under RCRA/PaDEP which does not require a permit for treatment, storage, or disposal.

NETL has instituted a practice of sending used toner cartridges to an offsite vendor who refills the cartridges and returns them to NETL - charging only for the cost of refilling the cartridges. This practice minimizes the necessity for purchasing replacement cartridges - either new or remanufactured. This practice has saved approximately $\$ 40 \mathrm{~K}$ per year since its inception. 
Executive Order 13148 requires the retrofit or replacement of $100 \%$ of chillers greater than 150 tons of cooling capacity and manufactured before 1984 using Class I refrigerants by 2005. NETL has two such chillers with a cooling capacity greater than 150 tons and a funding request in FY2001 has been submitted to FEMP to replace these chillers. Replacement of these chillers by 2005 will depend on availability of funding and budgetary restraints.

Additionally NETL plans to identify all Class I ozone-depleting substances by updating previous surveys, and then determining if an alternative to these substances is available. A plan will be developed to eliminate all Class I ozone- depleting substances (ODS) by 2010 to the extent economically practicable. To date, small class I ODS appliances (i.e. water coolers) are changed out as problems arise. 


\section{Site Hydrology, Groundwater Monitoring and Public Drinking Water Protection}

In September 1985, the Secretary of Energy announced a series of initiatives designed to strengthen the ES\&H programs and activities within the U.S. Department of Energy. As required by Chapter III of DOE Order 5400.1, General Environmental Protection Program, NETL developed groundwater protection management programs at the two sites. The purpose of the order was to establish environmental protection requirements, authorities, and responsibilities for DOE operations and to ensure compliance with applicable federal, state, and local environmental laws; executive orders; and DOE policies. The intent of DOE 5400.1 and the groundwater protection management program was to ensure that facility RCRA and CERCLA actions were addressed. Based on activities conducted at the sites, NETL was not subject to groundwater monitoring requirements as set forth under RCRA and CERCLA.

\subsection{Site Hydrology}

\section{Morgantown Site}

Most of Monongalia County is underlain by rocks of low permeability, which consequently yield water at low rates. Wells nearest the Morgantown site typically had yields of $0.1 \mathrm{~L} / \mathrm{s}$ (1.6 gallons per minute, gpm) or less. The principle aquifers were found in the Pennsylvanian-aged Conemaugh Group and the Pottsville Group. Aquifers of the Conemaugh Group outcrop at the Morgantown site were the source of most of the domestic water supplies near the area under water table (unconfined) conditions. Aquifers of the Pottsville Group, which are quite deep but are regarded as the most important aquifers in the county, yielded up to 250 gallons per minute (gpm) under artesian pressure, but averaged about 45 gpm. The Pottsville Group aquifers are separated from the Conemaugh Group aquifers by several hundred feet of bedrock. There is no apparent communication between these aquifers. One of the aquifers of the Conemaugh Group was sampled for possible contamination by monitoring wells at NETL, the Morgantown sandstones. The recharge area for this aquifer is east of Morgantown in the area of Chestnut Ridge, and discharges regionally into the Monongahela River west of the site. The Morgantown sandstone outcrops around the perimeter of the NETL property along Burroughs Run, West Run, and the Monongahela River. There are small springs in a number of places along these creeks and the Monongahela River where water flows from fractures in the Morgantown sandstone.

Unconformably overlying the Pennsylvanian rocks at the site is up to 70 feet of Pleistocene-aged unconsolidated Lake Monongahela sediments. These consist of a basal clayey sand that ranges from 10 to 20 feet in thickness, informally named the "A" aquifer, overlying interbedded clays and clayey sands, informally named the "B-C" aquifer, and a predominately sand unit, the "D" aquifer, which occurs at the surface on the southwest corner of the site. These sediments were deposited in stream and lacustrine environments from the glacial Lake Monongahela. The "A" and "B-C" units are water bearing under the developed part of the site and both are monitored for possible groundwater contamination at NETL. Both units extend off the site, and recharge is probably mostly from offsite, as the near-surface sediments are dominated by very low permeability clays in the developed area of the site. Both aquifers outcrop north of the developed area on the property, forming springs and small creeks which drain into 
West Run. There are probably springs and seeps along the Monongahela River from this unit as well. The groundwater monitoring program provides the following information:

- $\quad$ Baseline conditions of groundwater quality and quantity related to the site.

- $\quad$ Details of the groundwater/surface water relationship.

- Identification of potential sources of groundwater contamination.

- $\quad$ Data useful in the development an implementation of remedial measures for any NETL facilities/sites that could pose a concern to the environment.

- $\quad$ Measurement of petroleum hydrocarbons (diesel range organics) in groundwater at selected wells surrounding abandoned (or previously removed) storage tanks and oil spill areas, per state request.

\section{Pittsburgh Site}

Currently, 29 groundwater monitoring wells are at various locations throughout the Pittsburgh site. The groundwater management plan implementation included groundwater monitoring well installation, well development, and sampling and analysis to be completed in two phases. Phase I activities occurred from November 16, 1992, through February 12, 1993, and consisted of the installation of 16 bedrock wells, two piezometer clusters, and two stream gauging weirs. Phase II occurred from November 17, 1993, through February 17, 1994 and consisted of 12 additional bedrock wells. A concrete stream gauging station was also constructed during Phase I. Finally, a supplemental well was installed in June 1995.

The Pittsburgh site has two groundwater flow patterns. Groundwater flowing in the shallow, weathered bedrock aquifer may percolate along the soil/bedrock interface and along near-vertical stress relief fractures, and follows the general site topography, flowing from the tops of hills on the site, generally perpendicular to ground surface elevation contours. This flow is directed by the intervening valleys toward Lick Run Valley, where it joins the water-bearing unit in the valley and adds to the baseflow of Lick Run itself. Some of this flow also discharges as springs on the hillsides or in the valleys.

The second flow pattern is associated with the deep aquifer. Groundwater in this zone generally flows east toward Lick Run Valley, where it is joined by the water of the shallow zone as it flows off the hillsides.

For purposes of groundwater monitoring, the Pittsburgh site was divided into three separate areas generally referred to as the main plateau area, the valley fill area (which includes the 900 area, Building 141, and the 920 area, 2.1 acre, 2.2 acre, and 4.0 acre properties), and the Building 167/triangle parking lot area. These areas were selected based on current operations and historical areas of contamination. During 1998, a semiannual groundwater sampling and analysis 
program involving two contamination detection programs was completed.

\section{Data Analysis}

Tables 10 to 24 in the appendix present the results of groundwater data collected for the Pittsburgh and Morgantown sites. This analysis consisted of the following:

1. Investigation for immiscible (light or dense) organic phases, continued measurement for specific constituents identified during the initial monitoring phase, RCRA (background year) sampling/analyses, and subsequent RCRA sampling/analyses with statistical comparisons of contamination indicator parameter data.

2. Measurement of petroleum hydrocarbons (diesel range organics) in groundwater at selected wells surrounding inactive underground storage tanks and oil spill areas, per PaDEP request.

Results of laboratory analyses produced a variety of groundwater chemical constituent data that must be evaluated to determine whether the facility is contaminating the groundwater.

Downgradient contamination is indicated by one, or a combination of, the following conditions:

- Immiscible organic phases are detected downgradient, and contaminant concentrations are substantively elevated compared to upgradient/background (or none detected upgradient), and substantively exceed drinking water standard maximum contaminant levels (MCLs).

- $\quad$ As defined by Appendix IX to 40 CFR Part 264, dissolved hazardous waste constituents are detected downgradient, and concentrations are substantively elevated compared to upgradient/ background (or none detected upgradient) and substantively exceed MCLs (or human health evaluations identify a risk).

Statistical comparisons of semiannual contamination indicator data (upgradient and downgradient wells) were made against appropriate upgradient/background well data. If statistically significant downgradient differences exist (and are subsequently confirmed by immediate resampling and repeating of statistical analyses), then contamination will be indicated and a human health and ecological risk assessment and/or groundwater quality assessment program will be warranted. If no downgradient statistically significant differences are calculated, routine monitoring will continue.

\subsection{Groundwater Monitoring}

\section{Morgantown Site}

The objectives of groundwater monitoring were to provide environmental surveillance of each of the two shallow aquifers and the first regional aquifer, and environmental surveillance of a closed and abandoned 
wastewater pond. A total of 22 groundwater wells were monitored semiannually, four wells (three down gradient one up gradient) in the Morgantown aquifer, thirteen wells (ten down gradient and three up gradient) in the "A" aquifer, five wells in the "B-C" aquifer. The wells that monitor the abandoned wastewater pond are in the "A" aquifer.

The groundwater monitoring results for the Morgantown site are presented in Tables 19-24. None of the results exceeded state groundwater standards. Most parameters are monitored in detection mode, that is, results are typically nondetectable. For the parameters that are detected, a statistical analysis was conducted to compare up gradient and down gradient values. The following is a summary of the results:

- $\quad$ Nitrate, as nitrogen, was consistently higher than background levels in one well in the shallowest "B-C" aquifer and in many wells in the deeper unconsolidated "A" aquifer, but not higher in the regional Morgantown aquifer. No wells exceeded the West Virginia groundwater limit.

- $\quad$ Sodium and chloride were higher than background wells in the vicinity of roadways and walkways where salt is applied for de-icing purposes. West Virginia has not set a standard for sodium or chloride.

- Sulfate was consistently higher than background in detection wells in two wells in the "A" aquifer. West Virginia has not set a standard for sulfate.

- Fluoride was higher than background in three wells in the "A" aquifer and one well in the "B-C" aquifer. No wells exceeded the West Virginia groundwater limit.

No other parameters were statistically significantly higher in down gradient wells than up gradient levels.

\section{Pittsburgh Site}

Data gathered in support of groundwater monitoring at the Pittsburgh site is used to evaluate the changes noted in groundwater quality from baseline conditions of the various locations around the site. The primary objective of groundwater monitoring is to assess potential impacts on groundwater quality. The results of the NETL-PGH Groundwater Detection Monitoring Program are presented in Tables 10 to18. The results were compared against Federal and State Standards for Groundwater. The following is a summary of the results:

- Wells MPW-8 and VFW-3 exceeded primary drinking water standards for tetrachloroethene. Well MPW-8 is located near a previously operating mechanic shop. Well VFW-3 is located adjacent to a laboratory wastewater holding tank, which the overflow was connected to a french drain. The overflow was connected to the sanitary sewer more than thirteen years ago.

- Well MPW-7 exceeded primary drinking water standards for bis (2-ethylhexyl) phthalate. Bis (2-ethylhexyl) phthalate is a common laboratory contaminant. 
- $\quad$ Iron, manganese, sulfate, and total dissolved solids exceeded primary drinking water standards for four, seventeen, five, and twenty-one wells, respectively. This has been contributed to past mining activities.

- Wells MPW-1, MPW-7, VFW-11, and VFW-12 exceeded primary drinking water standards for nickel. The level has been attributed in the past to the interaction of the sodium and chloride with the stainless steel well casing.

- Well MPW-10 exceeded primary drinking water standards for $\mathrm{pH}$. This well is installed in a bedrock of limestone.

Statistical evaluation of the groundwater consisted of reestablishing background levels to reflect changing conditions and evaluating NETL's impact on groundwater quality. Statistical analysis was conducted on the indicators of groundwater contamination $[\mathrm{pH}$, conductivity, total organic halogen (TOX), and total organic carbon (TOC)].

When a difference is observed between two groundwater sampling results, it becomes a matter of statistics to determine whether the difference is small enough to be explained by chance. If the difference can be explained by chance, then it is reasonable to assume that the sampling results were the same. Conversely, when the difference is large, it is no longer reasonable to assume that the samples are the same. This process of determining whether the samples are or are not the same, is called the "null hypothesis."

NETL uses two different statistical methods to test the "null hypothesis" of its groundwater samples. The objective of both methods is to determine whether the level of contaminants detected in a sample can be explained by chance, assuming that the results are the same as would be obtained from a background sample. The Tolerance Interval-two tailed method tests for the null hypothesis by rejecting background tolerance levels falling into either tail (large or small end) of the parametric sampling distribution. The Wilcoxon Rank Sum Test tests for the null hypothesis when the data is not normally distributed. NETL used the Tolerance Interval-two tailed method for $\mathrm{pH}$, TOC and specific conductance of the VF samples, and the Wilcoxon Rank Sum Test for TOX and specific conductance of the MP samples.

The statistical analysis compared the up gradient wells (MPW-1, VFW-2, and VFW-10) to the down gradient wells. The following are the results of this statistical analysis:

- $\quad$ The $\mathrm{pH}$ values were outside the background tolerance levels in Wells MPW-4D, MPW- 10, and VFW-1.

- $\quad$ The conductivity values for the Main Plateau Wells had no significant change, while Wells VFW-6 and VFW-7 were outside the background tolerance intervals.

- $\quad$ The TOX values had no significant change. 
- $\quad$ The TOC values were outside the background tolerance levels in Wells VFW-1, VFW-3, VFW-4, VFW-5, VFW-7, VFW-12, and VFW-14.

An element of the Groundwater Detection Program is the Surface Water-Groundwater Interaction. A piezometer was monitored monthly along Lick Run upstream of the Site and a piezometer was monitored weekly along Lick Run adjunct to the Site to determine if Lick Run is a "gaining" or "losing" stream. A "gaining" stream has groundwater flowing to the stream, while a "losing" stream has surface water flowing to the groundwater. The data collected indicates that Lick Run upstream of the Site is a "gaining" stream, eight of the twelve months, while Lick Run adjunct to the Site is always a "gaining" stream. 


\section{Quality Assurance}

\section{Environmental Sampling and Analysis}

All environmental analyses at NETL were performed by an off-site subcontractor in accordance with NETL specifications. This subcontractor is well versed in U.S. EPA sampling protocol. The subcontractor was tasked with the fundamental responsibility of establishing and maintaining programs that ensure the reliability and validity of all analytical laboratory and field data. NETL's Quality Assurance (QA) Program demands continuing evidence of the subcontractor's commitment to fulfilling these obligations. The subcontractor's QA Program was implemented throughout the analytical process from preparation for sampling through data management and reporting to ensure reliable and valid analytical data.

Because of the nature of the sampling event, stormwater sampling, was performed by an on-site contractor using EPA protocol. The following types of samples were collected at NETL:

Groundwater Monitoring Wells - Groundwater samples were collected following Standard Operating Procedure (SOP) for groundwater monitoring well sampling.

Water/Wastewater/Other Discharges - Grab samples were collected following the same strategy outlined in the SOP for groundwater monitoring well sampling. Composite samples were taken using either flow or time weighted automatic samplers.

Sediments, Solids, Drums, Hazardous Wastes - Representative samples were taken by subcontractor personnel following correct sampling protocols. Adherence to appropriate SOP's (e.g., sample containers, preservation) was maintained.

\section{Standard Operating Procedures}

NETL required the subcontractor to have Standard Operating Procedures (SOPs) in place for all analytical, technical and administrative procedures.

\section{Training}

The subcontractors ensured that their personnel were trained both technically and with respect to the requirements of their Corporate Quality Assurance Manual, including the implementation of the quality assurance procedures.

\section{Testing}

Sampling and analytical services have been provided to NETL by the subcontractor for over 16 years. All testing was performed using approved EPA procedures (recent edition of SW-846) and met the requirements of any federal/state permits issued to NETL. Samples included:

- water or wastewater samples 
- $\quad$ solid waste samples

- $\quad$ hazardous waste samples

- $\quad$ soil samples

- $\quad$ stream sediment samples

- $\quad$ R\&D project samples

- $\quad$ process samples

Sample sources included:

- industrial wastewater discharge to the local POTW

- $\quad$ various sewer system discharges and manholes (i.e. stormwater, sanitary wastewater, process water, and industrial/contaminated wastewater)

- groundwater monitoring wells

- $\quad$ potable water system

- $\quad$ streams and rivers

- $\quad$ various pits and sumps

- $\quad$ R\&D projects

- $\quad$ spill and/or leaks

- $\quad$ soils

- $\quad$ solid and/or hazardous waste streams

The testing process followed well documented laboratory quality control (QC) protocol. These procedures defined the requirements for the generation of QC data, subsequent evaluation of the data, and the reporting procedures and statistical data analysis procedures used to provide feedback about the performance of an analytical system.

Where method guidelines were not available, the acceptance criteria used was EPA's contract lab procedure (CLP). If CLP guidelines were not available, internal acceptance criteria were used. It was the responsibility of each analytical staff member to perform all necessary quality control procedures and 
measurements, and to complete all appropriate documentation. Many of these requirements were specified in the methodologies used and were addressed in specific method SOPs.

There were, however, several quality control policies that were applicable to the majority of analytical procedures:

- $\quad$ Prior to the analysis of any sample, the analytical system must have met the required calibration criteria.

- $\quad$ Prior to any sample analysis, an instrument blank must have been performed to demonstrate that the analytical system is void of contamination.

- $\quad$ One method blank must have been analyzed for every prep or analytical batch.

- $\quad$ One laboratory control sample must have been analyzed for every prep or analytical batch.

- $\quad$ One matrix spike or matrix spike duplicate must have been performed for every prep batch.

Batching was the way in which groups of samples were assigned to specific QC measurements. Each prep batch had no more than 20 field samples of the same matrix, a method blank, a laboratory control sample, and a matrix spike/matrix spike duplicate. The contents and duration of an analytical batch were clarified in the method SOPs.

\section{Quality Control Data}

Outlined below are the various quality control measurements utilized by the analytical staff to assess data quality:

Duplicate Analysis: Two independent measurements for a particular analyte were acquired from the same analytical system on the same sample. This quality control measurement provided information concerning analytical precision.

Matrix Spike Analysis: A known concentration of the target analyte was added to the sample matrix. This spike analysis provided information concerning the analytical accuracy and matrix effect the sample may have on the recovery of the target analyte.

Matrix Spike/Matrix Spike Duplicate Analysis: This analysis was a matrix spike analysis performed in duplicate. This procedure provided information concerning both the precision and accuracy of the analytical system.

Surrogate Spike Analysis: A specific compound at a known concentration was added to the sample matrix. Because the surrogate compound was generally similar to the target compounds, its recovery should indicate some correlation to target compound recovery.

Laboratory Control Sample: This analysis was an independent source standard of known 
concentration. This type of analysis was necessary for verifying good laboratory practice.

\section{Control Charts}

A control chart is a means of looking at trends in the data. By having available a current control chart, the analyst can make determination of the current $\mathrm{QC}$ data to help judge the status of the analysis. The type of control chart used was the Shewhart Control Chart in the form of $\mathrm{x}, \mathrm{s}$ (X-bar, sigma).

The chart allowed the analyst to determine which data points (representing QC measurement events) were part of an out-of-control population and therefore indicative of possible problems in the analytical system. This procedure allowed the analyst to empirically differentiate between normal variation inherent in any measurement process and that variation attributable to a process moving away from the normal.

The chart was particularly useful for uncovering "trending." Trending is the characteristic of data in a given population to cluster on one side of the mean or show greater separation from the mean when the population is changing. Such behavior indicates to the analyst that measurement conditions may also be changing and investigation of the system may be warranted.

\section{Reporting}

All associated QC data was reported for each sample being analyzed. This was reported using the SOPs for Data Package Preparation.

\section{Waste Disposal}

Upon completion of all required analyses, all remaining samples, sample material, and contaminated sample containers was managed and/or disposed of in accordance with all applicable laws and regulations (RCRA regulations). The final disposition of these items was approved by NETL and was fully documented in quarterly Sample Disposition Reports.

All hazardous waste generated at NETL was disposed of in accordance with applicable Federal Regulations (EPA). Waste was placed in specified containers, labeled, and shipped to a contracted waste disposal firm.

The QA procedure for hazardous waste manifesting involved between two and four separate reviews, depending upon the complexity and quantity of the shipment. The Uniform Hazardous Waste Manifest was created by the licenced hazardous waste hauler one to two days prior to the shipping date. This provided an opportunity for the site support contractor hazardous waste technicians, project engineer, and DOE personnel to review and correct or adjust the Manifest to ensure that it complies with DOT and RCRA regulations. Changes were made to the manifest if needed and then it was signed by the DOE Hazardous Waste Program Manager. All personnel involved in hazardous waste disposal are trained annually to ensure familiarity with all applicable RCRA and DOT regulations.

During the shipping activities NETL QA personnel are present to ensure the following:

1. Hazardous waste manifests were prepared properly. 
2. The licenced transporter complied with all applicable DOT placarding requirements.

3. Hazardous waste did not exceed the permissible 90-day retention period.

4. The transport vehicle was properly identified (EPA ID Number, State Transporter Number).

5. The transporter driver had the proper DOT licensing.

6. Spill kits were available to the transport driver during transit.

7. The total number of loaded items conformed to the value listed on the Manifest.

8. Hazardous waste containers had the proper EPA labeling waste identification on the labels.

Any deficiencies were immediately corrected prior to the transport of the hazardous waste to the off-site TSD facility. There were no deficiencies in transported waste.

\section{Laboratory Certifications}

The subcontractor laboratory held the following certifications:

- State of Colorado Department of Health for Drinking Water Analysis

- State of Delaware Department of Health for Drinking Water Analysis

- State of Kentucky Department of Health for Drinking Water analysis

- State of Virginia Department of Health for Drinking Water Analysis

- State of Maryland Department of Health for Drinking Water Analysis

- State of Massachusetts Department of Health for Drinking Water Analysis

- State of Minnesota Department of Health for Drinking Water Analysis

- State of Michigan Department of Health for Drinking Water Analysis

- State of New Jersey Department of Health for Drinking Water Analysis

- State of Tennessee for Underground Storage Tank Program

- U.S. Department of Agriculture (USDA-APHIS) for the importation of foreign soil

- U.S. Drug Enforcement Agency for handling of controlled substances

- West Virginia Department of Health for Drinking Water Analysis

- West Virginia Division of Environmental Protection for NPDES Laboratory Certification Program

- West Virginia Board of Pharmacy for handling of controlled substance.

\section{Laboratory Proficiency Programs}

The subcontractor laboratory actively and regularly participated in various external performance evaluation programs, internally administered blind performance evaluations, and an internal corporate round robin program.

Performance Evaluation Samples (PES)

These samples were defined as third-party prepared check samples, whose values were known 
only to the third party prior to completion of the analyses. The subcontractor was made aware that the samples were PES but did not have access to the true value information until after the results were submitted. In all cases, these were analyzed by many laboratories and the results were reported so as to reference them to overall laboratory performance ("round robin" analysis). The PES, therefore, gave an independent measure of laboratory performance.

\section{Internal Blind Performance Evaluation Samples (IBPES)}

These samples, frequently referred to as "blinds," were check samples that were purchased or prepared by the QA/QC office and submitted to the laboratory as a regular sample. The lab staff had no knowledge that the sample was a check sample and it was processed in the normal fashion. While the PES gave a good assessment of optimum performance, the IBPES assessed usual performance. The QA/QC office was required to pass at least one IBPES through each analytical group (measuring as many parameters as possible) at a minimum of twice annually. Frequent use of independent check samples was made, along with standard reference materials obtained from various government agencies. All IBPES activity was documented in the QA/QC log kept for that purpose. NETL also submitted blind performance evaluation samples to the subcontractor periodically.

\section{Audits/Assessments from External Agencies}

An audit was a review of all procedures used in laboratory operations to assure compliance with the written QA/QC plan and written analytical SOPs. There were three types of audits performed:

\section{System Audit}

A comprehensive review of one analytical method (or a group of closely related methods) over a specific time period (one to three months at the discretion of the QA/QC officer). The following areas were part of a system audit:

- A review of the analytical results reported during the chosen time period.

- An interview with the analyst regarding pertinent analytical SOPs.

- A review of analytical run logs for the chosen time period.

- A review of calibration data over the same time period including the source and make-up of the calibrates.

- A review of QC data acquired (duplicates, spikes, blanks, and spike duplicates) for that time period.

- A review of the group's QC log to evaluate the documentation and corrective action taken of any out-of-control events for the method in question.

- A review of any and all instrument maintenance logs for instruments used in the analysis.

- An assessment of how easily the above documentation was retrieved.

The QA/QC office was required to conduct a system audit of each method or method group at a minimum of once every six moths. 


\section{Case Audit}

This consisted of following a single sample or set of samples through the entire analytical process, from sample intake and log-in to the final report. There was no minimum number of case audits required in a given time period, and audits were conducted at the QA/QC officer's discretion.

\section{Client and/or Third Party Audits}

The subcontractor was audited by professionals representing both regulatory agencies and clients. Recent audits include:

- West Virginia Department of Public Health - for West Virginia certification to perform drinking water analyses.

- West Virginia Division of Environmental Protection - for West Virginia NPDES certification.

- United States Department of Agriculture - for a federal permit to import foreign soil. 


\section{Abbreviations and Acronyms}

\begin{tabular}{|c|c|c|c|}
\hline AA/RC & $\begin{array}{l}\text { asbestos abatement/removal } \\
\text { contractor }\end{array}$ & HVAC & $\begin{array}{l}\text { heating, ventilation and air } \\
\text { conditioning }\end{array}$ \\
\hline ACHD & $\begin{array}{l}\text { Allegheny County (PA) Health } \\
\text { Department }\end{array}$ & IBPES & $\begin{array}{l}\text { international blind performance } \\
\text { evaluation samples }\end{array}$ \\
\hline ACM & $\begin{array}{ll}\text { asbestos- } \\
\text { containing } \\
\text { materials }\end{array}$ & ISMS & integrated safety management \\
\hline $\begin{array}{l}\text { AEA } \\
\text { AEO } \\
\text { BTEX }\end{array}$ & $\begin{array}{l}\text { Atomic Energy Act } \\
\text { Arctic Energy Office } \\
\text { benzene, toluene, ethyl } \\
\text { benzene, and xylenes }\end{array}$ & $\begin{array}{l}\text { ISUP } \\
\text { LWHT } \\
\text { MCL }\end{array}$ & $\begin{array}{l}\text { system } \\
\text { Industrial Sewer Use Permit } \\
\text { laboratory waste holding tank } \\
\text { maximum }\end{array}$ \\
\hline $\begin{array}{l}\text { BOD } \\
\text { CAA } \\
\text { CERCLA }\end{array}$ & $\begin{array}{l}\text { biological oxygen demand } \\
\text { Clean Air Act } \\
\text { Comprehensive Environmental }\end{array}$ & MGN & $\begin{array}{l}\text { NETL'S site at } \\
\text { Morgantown, } \\
\text { WV }\end{array}$ \\
\hline $\begin{array}{l}\text { CFC } \\
\text { CFR } \\
\text { CLP } \\
\text { CPICOR }\end{array}$ & $\begin{array}{l}\text { Response, Compensation and } \\
\text { Liability Act } \\
\text { chlorofluorohydrocarbans } \\
\text { U.S. Code of Federal Regulations } \\
\text { contract lab procedure } \\
\text { clean power from integrated } \\
\text { coal/ore reduction }\end{array}$ & $\begin{array}{l}\text { NEPA } \\
\text { NESHAP }\end{array}$ & $\begin{array}{l}\text { material safety data sheet } \\
\qquad \begin{array}{l}\text { Morgantown } \\
\text { Utility Board }\end{array} \\
\text { National Environmental Policy Act } \\
\text { National Emission Standards for } \\
\text { Hazardous Air Pollutants }\end{array}$ \\
\hline CWA & $\begin{array}{l}\text { coal/ore reduction } \\
\qquad \text { Clean Water } \\
\text { Act }\end{array}$ & NETL & $\begin{array}{l}\text { National Energy Technology } \\
\text { Laboratory }\end{array}$ \\
\hline DOE & U.S. Department of Energy & NIOSH & National Institute for Occupational \\
\hline & $\begin{array}{l}\text { Department of Transportation } \\
\text { environmental assessment }\end{array}$ & NOV & $\begin{array}{l}\text { Notice of Enforcement Action } \\
\text { Letters of Violation }\end{array}$ \\
\hline $\begin{array}{l}\text { EIS } \\
\text { EMS }\end{array}$ & $\begin{array}{l}\text { environmental impact statement } \\
\text { Environmental Management } \\
\text { System }\end{array}$ & NPDES & $\begin{array}{l}\text { National Pollutant Discharge } \\
\text { Elimination System }\end{array}$ \\
\hline $\begin{array}{l}\text { EPA } \\
\text { EPCRA }\end{array}$ & $\begin{array}{l}\text { Environmental Protection Agency } \\
\text { Emergency Planning and }\end{array}$ & $\begin{array}{l}\text { NPL } \\
\text { NPTO }\end{array}$ & $\begin{array}{l}\text { national priority list } \\
\text { National Petroleum Technology } \\
\text { Office }\end{array}$ \\
\hline $\begin{array}{l}\text { ERO } \\
\text { ESA } \\
\text { ES\&H } \\
\text { FETC }\end{array}$ & $\begin{array}{l}\text { Community Right-to-Know Act } \\
\text { emergency response organization } \\
\text { Endangered Species Act } \\
\text { environment, safety, and health } \\
\text { Federal Energy Technology Center }\end{array}$ & $\begin{array}{l}\text { NRC } \\
\text { OAQ } \\
\text { ODS } \\
\text { OSHA }\end{array}$ & $\begin{array}{l}\text { Nuclear Regulatory Commission } \\
\text { WV Office of Air Quality } \\
\text { Ozone Depleting Substances } \\
\text { U.S. Occupational Safety and } \\
\text { Health Administration }\end{array}$ \\
\hline $\begin{array}{l}\text { FFCA } \\
\text { FIFRA }\end{array}$ & $\begin{array}{l}\text { Federal Facilities Compliance Act } \\
\text { Federal Insecticide, Fungicide, and } \\
\text { Rodenticide Act }\end{array}$ & PaDEP & $\begin{array}{l}\text { Pennsylvania Department of } \\
\text { Environmental Protection }\end{array}$ \\
\hline $\begin{array}{l}\text { FONSI } \\
\text { FWS } \\
\text { HP }\end{array}$ & $\begin{array}{l}\text { Finding of No Significant Impact } \\
\text { Fish and Wildlife Service } \\
\text { horsepower }\end{array}$ & $\begin{array}{l}\text { PA } \\
\text { PCB } \\
\text { PDU }\end{array}$ & $\begin{array}{l}\text { preliminary assessment } \\
\text { polychlorinated biphenyl } \\
\text { process development unit }\end{array}$ \\
\hline
\end{tabular}




\begin{tabular}{|c|c|c|c|}
\hline PES & performance evaluation samples & TPQ & threshold planning quantity \\
\hline PFBC & Pennsylvania Fish and Boat & TRI & toxic release inventory \\
\hline & Commission & TSCA & Toxic Substances Control Act \\
\hline PGC & Pennsylvania Game Commission & TSS & total suspended solids \\
\hline PGH & NETL'S site at Pittsburgh, PA & TVA & Tennessee Valley Authority \\
\hline $\begin{array}{l}\text { PHA } \\
\text { PNDI }\end{array}$ & $\begin{array}{l}\text { Pleasant Hills (PA) Authority } \\
\text { Pennsylvania Natural Diversity }\end{array}$ & WDEQ & $\begin{array}{l}\text { Wyoming Department of } \\
\text { Environmental Quality }\end{array}$ \\
\hline POTW & $\begin{array}{l}\text { Inventory } \\
\text { Publicly Owned Treatment Works }\end{array}$ & WVDEP & $\begin{array}{l}\text { West Virginia Department of } \\
\text { Environmental Protection }\end{array}$ \\
\hline QA & Quality Assurance & WVDNR & West Virginia Division of Natural \\
\hline $\begin{array}{l}\text { QC } \\
\text { R\&D }\end{array}$ & $\begin{array}{l}\text { Quality Control } \\
\text { research and development }\end{array}$ & WWTF & $\begin{array}{l}\text { Resources } \\
\text { wastewater treatment facility }\end{array}$ \\
\hline RCRA & $\begin{array}{l}\text { Resource Conservation and } \\
\text { Recovery Act }\end{array}$ & & \\
\hline SARA & $\begin{array}{l}\text { Superfund Amendments and } \\
\text { Reauthorization Act }\end{array}$ & & \\
\hline SDWA & Safe Drinking Water Act & & \\
\hline SAR & safety and analysis review & & \\
\hline SARS & safety and analysis review system & & \\
\hline SEA & site evaluation accomplished & & \\
\hline SERC & $\begin{array}{l}\text { State Emergency Response } \\
\text { Commission }\end{array}$ & & \\
\hline SOPs & $\begin{array}{l}\text { Standard } \\
\text { Operating } \\
\text { Procedures }\end{array}$ & & \\
\hline TOC & total organic carbon & & \\
\hline TOX & total organic halide & & \\
\hline
\end{tabular}




\section{Appendix: Tables 7 to 24}

Table 7. NETL-PGH 2001 National Pollutant Discharge Elimination System Storm Water Analysis Results

\begin{tabular}{|c|c|c|c|c|}
\hline \multirow{2}{*}{ Constituent } & \multicolumn{4}{|c|}{ Sample Date } \\
\hline & $02 / 14 / 01$ & $6 / 20 / 01$ & 9/10/01 & $12 / 06 / 01$ \\
\hline \multicolumn{5}{|c|}{ North Outfall - PGH } \\
\hline Flow & $0.980 \mathrm{MGD}$ & $0.435 \mathrm{MGD}$ & 7.049 MGD & $0.356 \mathrm{MGD}$ \\
\hline Suspended Solids & $196 \mathrm{mg} / \mathrm{L}$ & $51 \mathrm{mg} / \mathrm{L}$ & $48 \mathrm{mg} / \mathrm{L}$ & $\mathrm{ND}$ \\
\hline CBOD5 & $10 \mathrm{mg} / \mathrm{L}$ & $3.9 \mathrm{mg} / \mathrm{L}$ & $8.6 \mathrm{mg} / \mathrm{L}$ & ND \\
\hline Oil and Grease & $10 \mathrm{mg} / \mathrm{L}$ & ND & ND & $9.9 \mathrm{mg} / \mathrm{L}$ \\
\hline Aluminum & $3.88 \mathrm{mg} / \mathrm{L}$ & $0.40 \mathrm{mg} / \mathrm{L}$ & $1.0 \mathrm{mg} / \mathrm{L}$ & ND \\
\hline Iron & $9.14 \mathrm{mg} / \mathrm{L}$ & $2.6 \mathrm{mg} / \mathrm{L}$ & $3.1 \mathrm{mg} / \mathrm{L}$ & $0.52 \mathrm{mg} / \mathrm{L}$ \\
\hline Manganese & $0.63 \mathrm{mg} / \mathrm{L}$ & $0.82 \mathrm{mg} / \mathrm{L}$ & $0.21 \mathrm{mg} / \mathrm{L}$ & $0.42 \mathrm{mg} / \mathrm{L}$ \\
\hline Lead & $\mathrm{ND}$ & $\mathrm{ND}$ & $16 \mu \mathrm{g} / \mathrm{L}$ & ND \\
\hline Mercury & $0.2 \mu \mathrm{g} / \mathrm{L}$ & $0.32 \mu \mathrm{g} / \mathrm{L}$ & ND & ND \\
\hline $\mathrm{pH}$ & 7.97 s.u. & 7.62 s.u. & 6.86 s.u. & 8.19 s.u. \\
\hline Ammonia Nitrogen & $0.64 \mathrm{mg} / \mathrm{L}$ & ND & $\mathrm{ND}$ & $\mathrm{ND}$ \\
\hline \multicolumn{5}{|c|}{ South Outfall - PGH } \\
\hline Flow & 1.737 MGD & 7.250 MGD & 4.130 MGD & $0.766 \mathrm{MGD}$ \\
\hline Suspended Solids & $88 \mathrm{mg} / \mathrm{L}$ & $69 \mathrm{mg} / \mathrm{L}$ & $51 \mathrm{mg} / \mathrm{L}$ & $11 \mathrm{mg} / \mathrm{L}$ \\
\hline Aluminum & $5.75 \mathrm{mg} / \mathrm{L}$ & $5.7 \mathrm{mg} / \mathrm{L}$ & $3.1 \mathrm{mg} / \mathrm{L}$ & $0.80 \mathrm{mg} / \mathrm{L}$ \\
\hline Iron & $3.56 \mathrm{mg} / \mathrm{L}$ & $1.7 \mathrm{mg} / \mathrm{L}$ & $1.6 \mathrm{mg} / \mathrm{L}$ & $0.91 \mathrm{mg} / \mathrm{L}$ \\
\hline Manganese & $0.38 \mathrm{mg} / \mathrm{L}$ & $0.26 \mathrm{mg} / \mathrm{L}$ & $0.091 \mathrm{mg} / \mathrm{L}$ & $0.30 \mathrm{mg} / \mathrm{L}$ \\
\hline Lead & ND & $30 \mu \mathrm{g} / \mathrm{L}$ & $7.3 \mu \mathrm{g} / \mathrm{L}$ & $15 \mu \mathrm{g} / \mathrm{L}$ \\
\hline $\mathrm{pH}$ & 7.57 s.u. & 7.63 s.u. & 6.82 s.u. & 7.76 s.u. \\
\hline Ammonia Nitrogen & $2.02 \mathrm{mg} / \mathrm{L}$ & $0.71 \mathrm{mg} / \mathrm{L}$ & ND & $2.8 \mathrm{mg} / \mathrm{L}$ \\
\hline
\end{tabular}

MGD = millions of gallons per day; s.u. = standard units: ND = Non Detected.

\section{NETL-MGN 2001 National Pollutant Discharge \\ Elimination System Storm Water Analysis Results}

\section{Outfalls - MGN}

Constituents

Cutoff
Conc.

\begin{tabular}{|c|c|}
\multicolumn{2}{|c|}{ Outfall 002 } \\
\hline $4 / 20 / 01$ & $9 / 19 / 01$ \\
\hline
\end{tabular}

Outfall 005

\begin{tabular}{l|l}
$4 / 20 / 01$ & $9 / 19 / 01$ \\
\hline
\end{tabular}
Outfall 010

\begin{tabular}{l|l}
$4 / 20 / 01$ & $9 / 19 / 01$ \\
\hline
\end{tabular} 


\begin{tabular}{|l|c|c|c|c|c|c|c|}
\hline Nitrate + Nitrite Nitrogen (Grab) & $0.68 \mathrm{mg} / \mathrm{L}$ & $1.0 \mathrm{mg} / \mathrm{L}$ & $0.5 \mathrm{mg} / \mathrm{L}$ & $0.89 \mathrm{mg} / \mathrm{L}$ & $0.42 \mathrm{mg} / \mathrm{L}$ & $\mathrm{NS}$ & $\mathrm{NS}$ \\
Ammonia Nitrogen (Grab) & $4 \mathrm{mg} / \mathrm{L}$ & $\mathrm{ND}$ & $1.2 \mathrm{mg} / \mathrm{L}$ & $\mathrm{ND}$ & $\mathrm{ND}$ & $\mathrm{ND}$ & $\mathrm{ND}$ \\
Fecal Coliform (Grab) & None & $\begin{array}{c}450 \\
\mathrm{col} / 100 \mathrm{~mL}\end{array}$ & $\mathrm{ND}$ & $\mathrm{ND}$ & $\begin{array}{c}6,000 \\
\mathrm{col} / 100 \mathrm{~mL}\end{array}$ & $\begin{array}{c}8.0 \\
\mathrm{col} / 100 \mathrm{~mL}\end{array}$ & $\mathrm{ND}$ \\
Total Suspended Solids (Grab) & $100 \mathrm{mg} / \mathrm{L}$ & $\mathrm{NS}$ & $\mathrm{NS}$ & $21 \mathrm{mg} / \mathrm{L}$ & $12 \mathrm{mg} / \mathrm{L}$ & $\mathrm{NS}$ & $\mathrm{NS}$ \\
\hline
\end{tabular}

NS = Not Sampled ND = Not Detected 
Table 8. NETL-PGH 2001 Wastewater Effluent Analysis (mg/L)

\begin{tabular}{|c|c|c|c|c|c|c|c|c|c|c|c|c|c|}
\hline Constituent & Permit Limit & & & & & & & & & & & & \\
\hline & Sampling Date & $01 / 30 / 01$ & $02 / 27 / 01$ & 03/27/01 & 04/25/01 & $05 / 23 / 01$ & $06 / 20 / 01$ & 07/24/01 & 08/01/01 & 09/05/01 & 10/02/01 & 11/14/01 & 12/06/01 \\
\hline \multicolumn{14}{|c|}{ Building 74 Wastewater Treatment Facility Effluent } \\
\hline Aluminum & None & ND & 0.11 & ND & 0.22 & $\mathrm{ND}$ & 0.11 & ND & ND & ND & ND & ND & ND \\
\hline Cadmium & None & ND & ND & ND & ND & ND & ND & ND & ND & ND & ND & ND & ND \\
\hline Chromium & None & ND & ND & ND & ND & ND & ND & ND & ND & ND & ND & ND & ND \\
\hline Copper & 0.08 & 0.02 & ND & ND & ND & ND & ND & 0.0099 & 0.022 & 0.0052 & ND & 0.0072 & 0.0056 \\
\hline Cyanide (Free) & $<0.005$ & 0.004 & 0.003 & 0.006 & 0.011 & ND & ND & ND & ND & ND & ND & ND & ND \\
\hline TOX & None & ND & ND & ND & 0.030 & ND & ND & ND & ND & 0.037 & ND & ND & 0.067 \\
\hline Iron & None & 0.32 & 0.40 & 0.20 & 0.31 & 0.44 & 0.23 & 0.22 & 0.36 & 0.22 & 0.34 & 0.30 & 0.58 \\
\hline Lead & None & ND & ND & ND & ND & ND & ND & ND & ND & ND & ND & ND & ND \\
\hline Mercury & $<0.0002$ & 0.0003 & ND & ND & ND & ND & ND & ND & 0.00048 & ND & ND & ND & ND \\
\hline Nickel & None & ND & ND & ND & ND & ND & 0.0052 & 0.011 & 0.010 & ND & 0.0058 & 0.0061 & ND \\
\hline Oil \& Grease & None & 2 & ND & $\mathrm{ND}$ & $\mathrm{ND}$ & $\mathrm{ND}$ & 6.1 & $\mathrm{ND}$ & $\mathrm{ND}$ & ND & 10 & 5.4 & 8.8 \\
\hline $\mathrm{pH}$ (s.u.) & $6.0-9.0$ & 7.8 & 8.9 & 9.1 & 8.4 & 7.7 & 7.4 & 7.4 & 7.5 & 7.8 & 7.8 & 8.1 & 8.9 \\
\hline Phenolics & 0.025 & 0.001 & ND & 0.006 & ND & ND & ND & $\mathrm{ND}$ & $\mathrm{ND}$ & ND & $\mathrm{ND}$ & $\mathrm{ND}$ & ND \\
\hline TSS & None & 1 & 1 & $\mathrm{ND}$ & 1 & ND & 10 & ND & ND & ND & $\mathrm{ND}$ & ND & 9.0 \\
\hline Tin & None & ND & ND & ND & ND & ND & ND & ND & ND & ND & ND & ND & ND \\
\hline Trichloromethane & $<0.005$ & ND & ND & ND & ND & $\mathrm{ND}$ & ND & ND & ND & ND & ND & ND & ND \\
\hline Zinc & None & 0.05 & ND & 0.01 & 0.02 & 0.021 & 0.035 & 0.042 & 0.032 & 0.021 & 0.029 & 0.023 & ND \\
\hline
\end{tabular}

$\mathrm{ND}=$ not detected $; \mathrm{TOX}=$ total organic halogens; TSS = total suspended solids; s.u. = standard units.

Standard/Guideline - Pleasant Hills Authority Industrial Sewer Use Permit, December 27, 2000.

Permit exceedances $=$ shaded value. 
Table 8. NETL-MGN 200 Wastewater Effluent Analysis (lb/d)

(continued)

\begin{tabular}{|c|c|c|c|c|c|c|c|c|c|c|c|c|c|c|}
\hline & Parameter & Limit & January & February & March & April & May & June & July & August & September & October & November & December \\
\hline Flow (MGD) & $\begin{array}{l}\text { Monthly Average } \\
\text { Daily Maximum }\end{array}$ & $\begin{array}{l}0.09 \\
0.15 \\
\end{array}$ & $\begin{array}{l}0.03 \\
0.06 \\
\end{array}$ & $\begin{array}{l}0.03 \\
0.07 \\
\end{array}$ & $\begin{array}{l}0.01 \\
0.02 \\
\end{array}$ & $\begin{array}{l}0.01 \\
0.03 \\
\end{array}$ & $\begin{array}{l}0.01 \\
0.02 \\
\end{array}$ & $\begin{array}{l}0.01 \\
0.06 \\
\end{array}$ & $\begin{array}{l}0.01 \\
0.04 \\
\end{array}$ & $\begin{array}{l}0.01 \\
0.02 \\
\end{array}$ & $\begin{array}{l}0.02 \\
0.08 \\
\end{array}$ & $\begin{array}{l}0.01 \\
0.11 \\
\end{array}$ & $\begin{array}{l}0.01 \\
0.05 \\
\end{array}$ & $\begin{array}{l}0.01 \\
0.04 \\
\end{array}$ \\
\hline BOD5 & $\begin{array}{l}\text { Monthly Average } \\
\text { Daily Maximum }\end{array}$ & $\begin{array}{l}\text { None } \\
\text { None }\end{array}$ & $\begin{array}{l}0.8 \\
1.6 \\
\end{array}$ & $\begin{array}{l}0.6 \\
1.5 \\
\end{array}$ & $\begin{array}{l}0.3 \\
0.6 \\
\end{array}$ & $\begin{array}{l}0.3 \\
0.8 \\
\end{array}$ & $\begin{array}{l}1.7 \\
3.3 \\
\end{array}$ & $\begin{array}{c}0.22 \\
1.3 \\
\end{array}$ & $\begin{array}{c}0.43 \\
1.7 \\
\end{array}$ & $\begin{array}{l}0.36 \\
0.72 \\
\end{array}$ & $\begin{array}{l}0.44 \\
1.74 \\
\end{array}$ & $\begin{array}{l}\text { ND } \\
\text { ND }\end{array}$ & $\begin{array}{l}1.17 \\
5.84 \\
\end{array}$ & $\begin{array}{l}\mathrm{ND} \\
\mathrm{ND}\end{array}$ \\
\hline TSS & $\begin{array}{l}\text { Monthly Average } \\
\text { Daily Maximum }\end{array}$ & $\begin{array}{l}\text { None } \\
\text { None }\end{array}$ & $\begin{array}{l}\mathrm{ND} \\
\mathrm{ND}\end{array}$ & $\begin{array}{l}\text { ND } \\
\text { ND }\end{array}$ & $\begin{array}{l}0.5 \\
1.0\end{array}$ & $\begin{array}{c}1.0 \\
3\end{array}$ & $\begin{array}{c}1.5 \\
3 \\
\end{array}$ & $\begin{array}{l}\text { ND } \\
\text { ND }\end{array}$ & $\begin{array}{l}0.8 \\
3.3 \\
\end{array}$ & $\begin{array}{c}1.0 \\
2\end{array}$ & $\begin{array}{c}1.5 \\
6 \\
\end{array}$ & $\begin{array}{l}\mathrm{ND} \\
\mathrm{ND}\end{array}$ & $\begin{array}{l}0.5 \\
2.5 \\
\end{array}$ & $\begin{array}{l}1.3 \\
5.3 \\
\end{array}$ \\
\hline Arsenic & $\begin{array}{l}\text { Monthly Average } \\
\text { Daily Maximum }\end{array}$ & $\begin{array}{l}0.005 \\
0.008 \\
\end{array}$ & $\begin{array}{l}\text { ND } \\
\text { ND } \\
\end{array}$ & $\begin{array}{l}\text { ND } \\
\text { ND } \\
\end{array}$ & $\begin{array}{l}\text { ND } \\
\text { ND } \\
\end{array}$ & $\begin{array}{l}\text { ND } \\
\text { ND } \\
\end{array}$ & $\begin{array}{l}\mathrm{ND} \\
\mathrm{ND} \\
\end{array}$ & $\begin{array}{c}0.0007 \\
0.004 \\
\end{array}$ & $\begin{array}{l}\mathrm{ND} \\
\mathrm{ND}\end{array}$ & $\begin{array}{l}\mathrm{ND} \\
\mathrm{ND}\end{array}$ & $\begin{array}{l}\mathrm{ND} \\
\mathrm{ND}\end{array}$ & $\begin{array}{l}\mathrm{ND} \\
\mathrm{ND}\end{array}$ & $\begin{array}{l}\text { ND } \\
\text { ND }\end{array}$ & $\begin{array}{l}\text { ND } \\
\text { ND }\end{array}$ \\
\hline Cadmium & $\begin{array}{l}\text { Monthly Average } \\
\text { Daily Maximum }\end{array}$ & $\begin{array}{l}\text { None } \\
\text { None }\end{array}$ & $\begin{array}{l}\mathrm{ND} \\
\mathrm{ND}\end{array}$ & $\begin{array}{l}\mathrm{ND} \\
\mathrm{ND}\end{array}$ & $\begin{array}{l}\text { ND } \\
\text { ND }\end{array}$ & $\begin{array}{l}\text { ND } \\
\text { ND }\end{array}$ & $\begin{array}{l}\text { ND } \\
\text { ND }\end{array}$ & $\begin{array}{l}\text { ND } \\
\text { ND }\end{array}$ & $\begin{array}{l}\text { ND } \\
\text { ND }\end{array}$ & $\begin{array}{l}\text { ND } \\
\text { ND }\end{array}$ & $\begin{array}{l}\text { ND } \\
\text { ND }\end{array}$ & $\begin{array}{l}\text { ND } \\
\text { ND }\end{array}$ & $\begin{array}{l}\text { ND } \\
\text { ND }\end{array}$ & $\begin{array}{l}\text { ND } \\
\text { ND }\end{array}$ \\
\hline Chromium & $\begin{array}{c}\text { Monthly Average } \\
\text { Daily Maximum }\end{array}$ & $\begin{array}{l}0.007 \\
0.011 \\
\end{array}$ & $\begin{array}{l}\mathrm{ND} \\
\mathrm{ND}\end{array}$ & $\begin{array}{l}0.002 \\
0.004 \\
\end{array}$ & $\begin{array}{l}\mathrm{ND} \\
\mathrm{ND}\end{array}$ & $\begin{array}{l}\text { ND } \\
\text { ND }\end{array}$ & $\begin{array}{l}\mathrm{ND} \\
\mathrm{ND}\end{array}$ & $\begin{array}{c}0.0005 \\
0.003 \\
\end{array}$ & $\begin{array}{l}\text { ND } \\
\text { ND }\end{array}$ & $\begin{array}{l}\text { ND } \\
\text { ND }\end{array}$ & $\begin{array}{l}\text { ND } \\
\text { ND }\end{array}$ & $\begin{array}{l}\text { ND } \\
\text { ND }\end{array}$ & $\begin{array}{l}\mathrm{ND} \\
\mathrm{ND}\end{array}$ & $\begin{array}{l}\text { ND } \\
\text { ND }\end{array}$ \\
\hline Copper & $\begin{array}{l}\text { Monthly Average } \\
\text { Daily Maximum }\end{array}$ & $\begin{array}{l}0.04 \\
0.06 \\
\end{array}$ & $\begin{array}{l}0.009 \\
0.017 \\
\end{array}$ & $\begin{array}{l}0.005 \\
0.011 \\
\end{array}$ & $\begin{array}{l}0.001 \\
0.002 \\
\end{array}$ & $\begin{array}{l}0.001 \\
0.003 \\
\end{array}$ & $\begin{array}{l}0.001 \\
0.002 \\
\end{array}$ & $\begin{array}{c}0.002 \\
0.01 \\
\end{array}$ & $\begin{array}{l}0.001 \\
0.004 \\
\end{array}$ & $\begin{array}{l}0.001 \\
0.003 \\
\end{array}$ & $\begin{array}{l}0.002 \\
0.008 \\
\end{array}$ & $\begin{array}{c}0.0007 \\
0.008 \\
\end{array}$ & $\begin{array}{c}0.002 \\
0.01 \\
\end{array}$ & $\begin{array}{l}0.01 \\
0.04 \\
\end{array}$ \\
\hline Cyanide & $\begin{array}{l}\text { Monthly Average } \\
\text { Daily Maximum }\end{array}$ & $\begin{array}{l}0.02 \\
0.03\end{array}$ & $\begin{array}{l}\text { ND } \\
\text { ND }\end{array}$ & $\begin{array}{l}\text { ND } \\
\text { ND }\end{array}$ & $\begin{array}{l}\mathrm{ND} \\
\mathrm{ND}\end{array}$ & $\begin{array}{l}\text { ND } \\
\text { ND }\end{array}$ & $\begin{array}{l}\text { ND } \\
\text { ND }\end{array}$ & $\begin{array}{l}\text { ND } \\
\text { ND }\end{array}$ & $\begin{array}{l}\text { ND } \\
\text { ND }\end{array}$ & $\begin{array}{l}\text { ND } \\
\text { ND }\end{array}$ & $\begin{array}{l}\text { ND } \\
\text { ND }\end{array}$ & $\begin{array}{l}\text { ND } \\
\text { ND }\end{array}$ & $\begin{array}{l}\text { ND } \\
\text { ND }\end{array}$ & $\begin{array}{l}\text { ND } \\
\text { ND }\end{array}$ \\
\hline Lead & $\begin{array}{l}\text { Monthly Average } \\
\text { Daily Maximum }\end{array}$ & $\begin{array}{l}0.025 \\
0.038 \\
\end{array}$ & $\begin{array}{l}\text { ND } \\
\text { ND }\end{array}$ & $\begin{array}{l}\text { ND } \\
\text { ND }\end{array}$ & $\begin{array}{l}\text { ND } \\
\text { ND }\end{array}$ & $\begin{array}{l}\text { ND } \\
\text { ND }\end{array}$ & $\begin{array}{l}\text { ND } \\
\text { ND }\end{array}$ & $\begin{array}{l}\text { ND } \\
\text { ND }\end{array}$ & $\begin{array}{l}\text { ND } \\
\text { ND }\end{array}$ & $\begin{array}{l}\text { ND } \\
\text { ND }\end{array}$ & $\begin{array}{l}\text { ND } \\
\text { ND }\end{array}$ & $\begin{array}{l}\text { ND } \\
\text { ND }\end{array}$ & $\begin{array}{l}\text { ND } \\
\text { ND }\end{array}$ & $\begin{array}{l}\text { ND } \\
\text { ND }\end{array}$ \\
\hline Mercury & $\begin{array}{l}\text { Monthly Average } \\
\text { Daily Maximum }\end{array}$ & $\begin{array}{l}0.0006 \\
0.0009 \\
\end{array}$ & $\begin{array}{l}\mathrm{ND} \\
\mathrm{ND}\end{array}$ & $\begin{array}{l}\text { ND } \\
\text { ND }\end{array}$ & $\begin{array}{l}\mathrm{ND} \\
\mathrm{ND}\end{array}$ & $\begin{array}{l}\text { ND } \\
\text { ND }\end{array}$ & $\begin{array}{l}\text { ND } \\
\text { ND }\end{array}$ & $\begin{array}{l}\text { ND } \\
\text { ND }\end{array}$ & $\begin{array}{l}\text { ND } \\
\text { ND }\end{array}$ & $\begin{array}{l}\text { ND } \\
\text { ND }\end{array}$ & $\begin{array}{l}\text { ND } \\
\text { ND }\end{array}$ & $\begin{array}{l}\text { ND } \\
\text { ND }\end{array}$ & $\begin{array}{l}\text { ND } \\
\text { ND }\end{array}$ & $\begin{array}{l}\text { ND } \\
\text { ND }\end{array}$ \\
\hline Nickel & $\begin{array}{l}\text { Monthly Average } \\
\text { Daily Maximum }\end{array}$ & $\begin{array}{c}0.01 \\
0.015 \\
\end{array}$ & $\begin{array}{l}\mathrm{ND} \\
\mathrm{ND}\end{array}$ & $\begin{array}{l}\mathrm{ND} \\
\mathrm{ND} \\
\end{array}$ & $\begin{array}{l}\mathrm{ND} \\
\mathrm{ND} \\
\end{array}$ & $\begin{array}{l}\mathrm{ND} \\
\mathrm{ND}\end{array}$ & $\begin{array}{l}\text { ND } \\
\text { ND }\end{array}$ & $\begin{array}{l}\text { ND } \\
\text { ND }\end{array}$ & $\begin{array}{l}\text { ND } \\
\text { ND }\end{array}$ & $\begin{array}{l}\text { ND } \\
\text { ND }\end{array}$ & $\begin{array}{l}\mathrm{ND} \\
\mathrm{ND} \\
\end{array}$ & $\begin{array}{c}0.0005 \\
0.006 \\
\end{array}$ & $\begin{array}{l}\mathrm{ND} \\
\mathrm{ND}\end{array}$ & $\begin{array}{l}\mathrm{ND} \\
\mathrm{ND}\end{array}$ \\
\hline Silver & $\begin{array}{l}\text { Monthly Average } \\
\text { Daily Maximum }\end{array}$ & $\begin{array}{l}0.011 \\
0.017 \\
\end{array}$ & $\begin{array}{l}\text { ND } \\
\text { ND }\end{array}$ & $\begin{array}{l}\text { ND } \\
\text { ND }\end{array}$ & $\begin{array}{l}\mathrm{ND} \\
\mathrm{ND}\end{array}$ & $\begin{array}{l}0.0005 \\
0.001\end{array}$ & $\begin{array}{l}\text { ND } \\
\text { ND }\end{array}$ & $\begin{array}{l}\text { ND } \\
\text { ND }\end{array}$ & $\begin{array}{l}\text { ND } \\
\text { ND }\end{array}$ & $\begin{array}{l}\text { ND } \\
\text { ND }\end{array}$ & $\begin{array}{l}\mathrm{ND} \\
\mathrm{ND}\end{array}$ & $\begin{array}{l}\mathrm{ND} \\
\mathrm{ND}\end{array}$ & $\begin{array}{l}\text { ND } \\
\text { ND }\end{array}$ & $\begin{array}{l}\mathrm{ND} \\
\mathrm{ND}\end{array}$ \\
\hline Zinc & $\begin{array}{l}\text { Monthly Average } \\
\text { Daily Maximum }\end{array}$ & $\begin{array}{l}0.2 \\
0.3\end{array}$ & $\begin{array}{l}0.013 \\
0.026\end{array}$ & $\begin{array}{l}0.022 \\
0.051\end{array}$ & $\begin{array}{l}0.006 \\
0.011\end{array}$ & $\begin{array}{c}0.013 \\
0.04\end{array}$ & $\begin{array}{l}0.005 \\
0.009\end{array}$ & $\begin{array}{l}0.01 \\
0.07\end{array}$ & $\begin{array}{l}0.01 \\
0.03\end{array}$ & $\begin{array}{l}0.01 \\
0.02\end{array}$ & $\begin{array}{l}0.01 \\
0.05\end{array}$ & $\begin{array}{l}0.01 \\
0.09\end{array}$ & $\begin{array}{l}0.01 \\
0.03\end{array}$ & $\begin{array}{l}0.01 \\
0.03\end{array}$ \\
\hline Iron & $\begin{array}{l}\text { Monthly Average } \\
\text { Daily Maximum }\end{array}$ & $\begin{array}{l}\text { None } \\
\text { None }\end{array}$ & $\begin{array}{l}0.11 \\
0.21 \\
\end{array}$ & $\begin{array}{c}0.1 \\
0.22 \\
\end{array}$ & $\begin{array}{l}0.02 \\
0.04 \\
\end{array}$ & $\begin{array}{l}0.04 \\
0.13 \\
\end{array}$ & $\begin{array}{l}0.04 \\
0.08 \\
\end{array}$ & $\begin{array}{l}0.08 \\
0.45 \\
\end{array}$ & $\begin{array}{l}0.03 \\
0.12 \\
\end{array}$ & $\begin{array}{l}0.07 \\
0.14 \\
\end{array}$ & $\begin{array}{c}0.1 \\
0.39 \\
\end{array}$ & $\begin{array}{c}0.05 \\
0.5 \\
\end{array}$ & $\begin{array}{l}0.05 \\
0.23 \\
\end{array}$ & $\begin{array}{l}0.05 \\
0.19 \\
\end{array}$ \\
\hline Manganese & $\begin{array}{l}\text { Monthly Average } \\
\text { Daily Maximum }\end{array}$ & $\begin{array}{l}\text { None } \\
\text { None }\end{array}$ & $\begin{array}{l}0.024 \\
0.049 \\
\end{array}$ & $\begin{array}{l}0.04 \\
0.09 \\
\end{array}$ & $\begin{array}{l}0.01 \\
0.02 \\
\end{array}$ & $\begin{array}{l}0.02 \\
0.06 \\
\end{array}$ & $\begin{array}{l}0.02 \\
0.04 \\
\end{array}$ & $\begin{array}{l}0.01 \\
0.03 \\
\end{array}$ & $\begin{array}{l}0.01 \\
0.05 \\
\end{array}$ & $\begin{array}{c}0.003 \\
0.05 \\
\end{array}$ & $\begin{array}{c}0.004 \\
0.15 \\
\end{array}$ & $\begin{array}{l}0.01 \\
0.15 \\
\end{array}$ & $\begin{array}{l}0.01 \\
0.07 \\
\end{array}$ & $\begin{array}{l}0.01 \\
0.05 \\
\end{array}$ \\
\hline Phenolics & $\begin{array}{l}\text { Monthly Average } \\
\text { Daily Maximum }\end{array}$ & $\begin{array}{l}\text { None } \\
\text { None } \\
\end{array}$ & $\begin{array}{l}\mathrm{ND} \\
\mathrm{ND}\end{array}$ & $\begin{array}{l}\mathrm{ND} \\
\mathrm{ND} \\
\end{array}$ & $\begin{array}{l}\mathrm{ND} \\
\mathrm{ND}\end{array}$ & $\begin{array}{l}\mathrm{ND} \\
\mathrm{ND}\end{array}$ & $\begin{array}{l}\text { ND } \\
\text { ND }\end{array}$ & $\begin{array}{l}\mathrm{ND} \\
\mathrm{ND}\end{array}$ & $\begin{array}{l}\mathrm{ND} \\
\mathrm{ND}\end{array}$ & $\begin{array}{l}\mathrm{ND} \\
\mathrm{ND}\end{array}$ & $\begin{array}{l}\mathrm{ND} \\
\mathrm{ND} \\
\end{array}$ & $\begin{array}{l}\mathrm{ND} \\
\mathrm{ND}\end{array}$ & $\begin{array}{l}\mathrm{ND} \\
\mathrm{ND} \\
\end{array}$ & $\begin{array}{l}\mathrm{ND} \\
\mathrm{ND}\end{array}$ \\
\hline Total Organi & $\begin{array}{l}\text { ic Halogens } \\
\text { Monthly Average } \\
\text { Daily Maximum }\end{array}$ & $\begin{array}{l}\text { None } \\
\text { None }\end{array}$ & $\begin{array}{l}0.025 \\
0.05\end{array}$ & $\begin{array}{l}0.023 \\
0.053\end{array}$ & $\begin{array}{l}0.008 \\
0.015\end{array}$ & $\begin{array}{l}0.01 \\
0.03\end{array}$ & $\begin{array}{c}0.006 \\
0.01\end{array}$ & $\begin{array}{c}0.007 \\
0.04\end{array}$ & $\begin{array}{l}0.007 \\
0.029\end{array}$ & $\begin{array}{l}0.005 \\
0.011\end{array}$ & $\begin{array}{l}0.003 \\
0.013\end{array}$ & $\begin{array}{l}0.007 \\
0.074\end{array}$ & $\begin{array}{c}0.008 \\
0.04\end{array}$ & $\begin{array}{c}0.007 \\
0.03\end{array}$ \\
\hline Organics & $\begin{array}{l}\text { Monthly Average } \\
\text { Daily Maximum }\end{array}$ & $\begin{array}{l}\text { None } \\
\text { None }\end{array}$ & $\begin{array}{l}\text { NS } \\
\text { NS }\end{array}$ & $\begin{array}{l}\text { NS } \\
\text { NS }\end{array}$ & $\begin{array}{l}\text { NS } \\
\text { NS }\end{array}$ & $\begin{array}{l}\text { ND } \\
\text { ND }\end{array}$ & $\begin{array}{l}\text { NS } \\
\text { NS }\end{array}$ & $\begin{array}{l}\text { NS } \\
\text { NS }\end{array}$ & $\begin{array}{l}\text { NS } \\
\text { NS }\end{array}$ & $\begin{array}{l}\text { NS } \\
\text { NS }\end{array}$ & $\begin{array}{l}\text { NS } \\
\text { NS }\end{array}$ & $\begin{array}{l}\text { NS } \\
\text { NS }\end{array}$ & $\begin{array}{l}\text { NS } \\
\text { NS }\end{array}$ & $\begin{array}{l}\text { NS } \\
\text { NS }\end{array}$ \\
\hline
\end{tabular}




\begin{tabular}{|c|c|c|c|c|c|c|c|c|c|c|c|c|c|c|}
\hline pH (s.u.) & $\begin{array}{l}\text { Minimum } \\
\text { Maximum }\end{array}$ & $\begin{array}{l}6.0 \\
9.0\end{array}$ & $\begin{array}{l}6.6 \\
8.0\end{array}$ & $\begin{array}{l}6.1 \\
8.4\end{array}$ & $\begin{array}{l}6.3 \\
7.4\end{array}$ & $\begin{array}{l}6.7 \\
8.1\end{array}$ & $\begin{array}{l}6.0 \\
7.6\end{array}$ & $\begin{array}{l}6.8 \\
8.0\end{array}$ & $\begin{array}{l}6.2 \\
7.9\end{array}$ & $\begin{array}{l}7.2 \\
8.8\end{array}$ & $\begin{array}{l}7.6 \\
8.5\end{array}$ & $\begin{array}{l}6.2 \\
8.2\end{array}$ & $\begin{array}{l}7.1 \\
8.7\end{array}$ & $\begin{array}{l}6.2 \\
8.3\end{array}$ \\
\hline
\end{tabular}

MGD = millions of gallons per day; NS = not sampled; ND = not detected; TSS = total suspended solids; BOD5 = biological oxygen demand for 5-day period; s.u. = standard units. 
Table 9. 2001 NETL-PGH Industrial Sewer Use Permit Monitoring Analysis

\begin{tabular}{|c|c|c|c|c|c|c|}
\hline Constituent & Free Cyanide & Phenol & Copper & Mercury & Chloroform & pH \\
\hline Permit Limit & $<0.010 \mathrm{mg} / \mathrm{L}$ & $0.050 \mathrm{mg} / \mathrm{L}$ & $0.08 \mathrm{mg} / \mathrm{L}$ & $<0.0002 \mathrm{mg} / \mathrm{L}$ & $<10 \mathrm{ug} / \mathrm{L}$ & 6.0 - 9.0 s.u. \\
\hline \multicolumn{7}{|c|}{ April 25, 2001 Sampling Date } \\
\hline \multicolumn{7}{|c|}{ Subinterceptor Location } \\
\hline Composite & N/A & N/A & $0.06 \mathrm{mg} / \mathrm{L}$ & $0.00023 \mathrm{mg} / \mathrm{L}$ & N/A & N/A \\
\hline Grab \#1 & $0.003 \mathrm{mg} / \mathrm{L}$ & $0.009 \mathrm{mg} / \mathrm{L}$ & N/A & $\mathrm{N} / \mathrm{A}$ & ND & 7.77 s.u. \\
\hline Grab \#2 & $0.004 \mathrm{mg} / \mathrm{L}$ & $0.017 \mathrm{mg} / \mathrm{L}$ & N/A & N/A & ND & 8.14 s.u. \\
\hline Grab \#3 & $0.003 \mathrm{mg} / \mathrm{L}$ & $0.026 \mathrm{mg} / \mathrm{L}$ & N/A & N/A & ND & 8.17 s.u. \\
\hline Grab \#4 & $\mathrm{ND}$ & $0.013 \mathrm{mg} / \mathrm{L}$ & N/A & N/A & ND & 8.02 s.u. \\
\hline \multicolumn{7}{|l|}{ Building 74 Effluent } \\
\hline Composite & $\mathrm{N} / \mathrm{A}$ & $\mathrm{N} / \mathrm{A}$ & ND & ND & N/A & N/A \\
\hline Grab \#1 & $0.018 \mathrm{mg} / \mathrm{L}$ & $0.005 \mathrm{mg} / \mathrm{L}$ & $\mathrm{N} / \mathrm{A}$ & $\mathrm{N} / \mathrm{A}$ & $\mathrm{ND}$ & 8.11 s.u. \\
\hline Grab \#2 & $0.014 \mathrm{mg} / \mathrm{L}$ & $0.002 \mathrm{mg} / \mathrm{L}$ & N/A & N/A & $\mathrm{ND}$ & 8.57 s.u. \\
\hline Grab \#3 & $0.015 \mathrm{mg} / \mathrm{L}$ & $0.003 \mathrm{mg} / \mathrm{L}$ & N/A & N/A & $\mathrm{ND}$ & 8.53 s.u. \\
\hline Grab \#4 & $0.011 \mathrm{mg} / \mathrm{L}$ & ND & N/A & N/A & ND & 8.56 s.u. \\
\hline \multicolumn{7}{|c|}{ October 2, 2001 Sample Date } \\
\hline \multicolumn{7}{|l|}{ Subinterceptor Location } \\
\hline Composite & N/A & $\mathrm{N} / \mathrm{A}$ & $0.092 \mathrm{mg} / \mathrm{L}$ & $0.00026 \mathrm{mg} / \mathrm{L}$ & N/A & N/A \\
\hline \Grab \#1 & $\mathrm{ND}$ & $0.012 \mathrm{mg} / \mathrm{L}$ & N/A & N/A & ND & 7.90 s.u. \\
\hline Grab \#2 & ND & $0.0083 \mathrm{mg} / \mathrm{L}$ & N/A & N/A & ND & 8.61 s.u. \\
\hline Grab \#3 & ND & $0.0091 \mathrm{mg} / \mathrm{L}$ & N/A & N/A & ND & 8.74 s.u. \\
\hline Grab \#4 & ND & $0.017 \mathrm{mg} / \mathrm{L}$ & N/A & N/A & $\mathrm{ND}$ & 8.26 s.u. \\
\hline \multicolumn{7}{|l|}{ Building 74 Effluent } \\
\hline Composite & $\mathrm{N} / \mathrm{A}$ & N/A & ND & $\mathrm{ND}$ & N/A & $\mathrm{N} / \mathrm{A}$ \\
\hline Grab \#1 & ND & $\mathrm{ND}$ & N/A & N/A & $\mathrm{ND}$ & 8.21 s.u. \\
\hline Grab \#2 & $\mathrm{ND}$ & $\mathrm{ND}$ & $\mathrm{N} / \mathrm{A}$ & N/A & $\mathrm{ND}$ & 8.39 s.u. \\
\hline Grab \#3 & ND & ND & N/A & N/A & $\mathrm{ND}$ & 8.36 s.u. \\
\hline Grab \#4 & $\mathrm{ND}$ & $\mathrm{ND}$ & N/A & N/A & $\mathrm{ND}$ & 8.16 s.u. \\
\hline
\end{tabular}

$\mathrm{ND}=$ not detected; $\mathrm{N} / \mathrm{A}=$ not applicable; s.u. = standard units; $\mathrm{mg} / \mathrm{L}=$ milligrams per liter; $\mu \mathrm{g} / \mathrm{L}=$ micrograms per liter; permit exceedances $=$ shaded values. 
Table 10. NETL-PGH 2001 Groundwater Detection Monitoring Program Results of Analysis - Groundwater Samples, Main Plateau - Contamination Indicator Constituents

\begin{tabular}{|c|c|c|c|c|c|c|c|c|c|c|c|c|c|c|c|}
\hline \multirow[b]{3}{*}{ Week } & \multirow{3}{*}{\begin{tabular}{|l|} 
Constituents \\
\\
Sample Event \\
\end{tabular}} & \multicolumn{14}{|c|}{ Well } \\
\hline & & \multicolumn{2}{|c|}{ MPW-1 } & \multirow{2}{*}{$\begin{array}{l}\text { MPW-1-1 } \\
\text { Round 2 } \\
\end{array}$} & \multicolumn{2}{|c|}{ MPW-2 } & \multirow{2}{*}{$\begin{array}{l}\text { MPW-2-1 } \\
\text { Round } 1 / 2 \\
\end{array}$} & \multicolumn{2}{|c|}{ MPW-4 } & \multirow{2}{*}{$\begin{array}{l}\text { MPW-4-1 } \\
\text { Round } 2 \\
\end{array}$} & \multicolumn{2}{|c|}{ MPW-4D } & \multirow{2}{*}{$\begin{array}{c}\text { MPW-4D- } \\
1 \\
\text { Round } 2 \\
\end{array}$} & \multicolumn{2}{|c|}{ MPW-7 } \\
\hline & & Round 1 & Round 2 & & Round 1 & Round 2 & & Round 1 & Round 2 & & Round 1 & Round 2 & & Round 1 & Round 2 \\
\hline \multirow{6}{*}{ Week 1} & Sample Date & $05 / 09 / 01$ & 08/07/01 & 08/07/01 & 05/08/01 & 08/07/01 & 05/08/01 & 05/08/01 & 08/07/01 & N/A & 05/08/01 & 08/07/01 & N/A & $05 / 07 / 01$ & 08/07/01 \\
\hline & $\mathrm{pH}$ (standard units) & 7.03 & 7.18 & 7.18 & 6.70 & 7.17 & 6.70 & 6.92 & 7.30 & N/A & 7.77 & 8.38 & N/A & 6.86 & 7.08 \\
\hline & Specific Conductance & 2010 & 3260 & 3260 & 3570 & 3380 & 3570 & 2150 & 2080 & N/A & 840 & 820 & N/A & 3200 & 1240 \\
\hline & Temperature $\left({ }^{\circ} \mathrm{C}\right)$ & 15.1 & 18.0 & 18.0 & 13.6 & 15.1 & 13.6 & 12.7 & 16.0 & N/A & 13.2 & 15.5 & N/A & 15.9 & 17.1 \\
\hline & TOX $(\mu \mathrm{g} / \mathrm{L})$ & ND & $\mathrm{ND}$ & ND & $\mathrm{ND}$ & ND & $\mathrm{ND}$ & ND & $\mathrm{ND}$ & N/A & ND & ND & N/A & $\mathrm{ND}$ & ND \\
\hline & TOC $(\mathrm{mg} / \mathrm{L})$ & 8.5 & 2.7 & 3.0 & 1.9 & 2.2 & 3.1 & 3.4 & 1.6 & N/A & 3.4 & 3.0 & N/A & 3.6 & 3.5 \\
\hline \multirow{6}{*}{ Week 2} & Sample Date & $05 / 24 / 01$ & $09 / 06 / 01$ & N/A & $05 / 25 / 01$ & $09 / 06 / 01$ & N/A & $05 / 25 / 01$ & $09 / 06 / 01$ & N/A & $05 / 25 / 01$ & 09/06/01 & N/A & $05 / 24 / 01$ & 09/06/01 \\
\hline & $\mathrm{pH}$ (standard units) & 7.98 & 6.79 & N/A & 6.95 & 6.97 & N/A & 7.01 & 7.00 & N/A & 7.78 & 8.29 & N/A & NS & 6.80 \\
\hline & Specific Conductance & 3490 & 3230 & N/A & 3840 & 4200 & N/A & 2460 & 2720 & N/A & 940 & 1000 & N/A & NS & 1370 \\
\hline & Temperature $\left({ }^{\circ} \mathrm{C}\right)$ & 14.8 & 13.1 & N/A & 13.5 & 14.3 & N/A & 13.1 & 15.1 & N/A & 13.5 & 15.2 & N/A & NS & 16.5 \\
\hline & TOX $(\mu \mathrm{g} / \mathrm{L})$ & ND & ND & N/A & ND & ND & N/A & $\mathrm{ND}$ & $\mathrm{ND}$ & N/A & $\mathrm{ND}$ & $\mathrm{ND}$ & N/A & ND & ND \\
\hline & TOC $(\mathrm{mg} / \mathrm{L})$ & 3.0 & 8.3 & N/A & 2.1 & 6.9 & N/A & 1.8 & 9.2 & N/A & 2.9 & 11 & N/A & 3.5 & 8.9 \\
\hline \multirow{6}{*}{ Week 3} & Sample Date & $06 / 22 / 01$ & $10 / 02 / 01$ & N/A & $06 / 21 / 01$ & $10 / 02 / 01$ & $10 / 02 / 01$ & $06 / 21 / 01$ & $10 / 02 / 01$ & N/A & $06 / 21 / 01$ & $10 / 02 / 01$ & $06 / 21 / 01$ & $06 / 21 / 01$ & $10 / 02 / 01$ \\
\hline & $\mathrm{pH}$ (standard units) & 7.12 & 6.87 & N/A & 6.85 & 6.60 & 6.60 & 6.89 & 7.11 & N/A & 7.99 & 8.32 & 7.99 & 6.95 & 6.65 \\
\hline & Specific Conductance & 3340 & 4040 & N/A & 3620 & 4610 & 4610 & 2190 & 2840 & N/A & 900 & 1080 & 900 & 1860 & 1510 \\
\hline & Temperature $\left({ }^{\circ} \mathrm{C}\right)$ & 14.8 & 13.4 & N/A & 14.1 & 14.4 & 14.4 & 14.8 & 16.2 & N/A & 15.1 & 15.4 & 15.1 & 17.0 & 17.7 \\
\hline & $\mathrm{TOX}(\mu \mathrm{g} / \mathrm{L})$ & $\mathrm{ND}$ & ND & N/A & $\mathrm{ND}$ & $\mathrm{ND}$ & ND & ND & $\mathrm{ND}$ & N/A & $\mathrm{ND}$ & ND & $\mathrm{ND}$ & ND & ND \\
\hline & TOC $(\mathrm{mg} / \mathrm{L})$ & 19 & 13 & N/A & 2.5 & 15 & 14 & 3.3 & 20 & N/A & 3.0 & 23 & 1.6 & 3.2 & 23 \\
\hline \multirow{6}{*}{ Week 4} & Sample Date & $07 / 25 / 01$ & $11 / 15 / 01$ & N/A & $07 / 25 / 01$ & $11 / 15 / 01$ & N/A & $07 / 25 / 01$ & $11 / 15 / 01$ & $11 / 15 / 01$ & $07 / 25 / 01$ & $11 / 15 / 01$ & N/A & $07 / 25 / 01$ & $11 / 15 / 01$ \\
\hline & $\mathrm{pH}$ (standard units) & 7.16 & 6.74 & N/A & 6.78 & 6.83 & N/A & 7.08 & 6.92 & 6.92 & 8.10 & 7.74 & N/A & 6.84 & 6.83 \\
\hline & Specific Conductance & 3220 & 3670 & N/A & 3420 & 4060 & N/A & 2040 & 2630 & 2630 & 840 & 930 & N/A & 1560 & 1020 \\
\hline & Temperature $\left({ }^{\circ} \mathrm{C}\right)$ & 18.4 & 13.4 & N/A & 14.7 & 14.4 & N/A & 16.0 & 14.9 & 14.99 & 16.8 & 14.3 & N/A & 17.5 & 16.7 \\
\hline & $\mathrm{TOX}(\mu \mathrm{g} / \mathrm{L})$ & ND & ND & N/A & ND & $\mathrm{ND}$ & N/A & ND & ND & ND & $\mathrm{ND}$ & ND & N/A & ND & ND \\
\hline & TOC $(\mathrm{mg} / \mathrm{L})$ & 2.4 & 21 & N/A & 2.5 & 16 & N/A & 3.5 & 21 & 23 & 3.3 & 27 & N/A & 3.5 & 20 \\
\hline \multirow{5}{*}{$\begin{array}{l}2001 \\
\text { Range }\end{array}$} & $\mathrm{pH}$ (standard units) & \multicolumn{2}{|c|}{$6.74-7.98$} & N/A & \multicolumn{2}{|c|}{$6.60-7.17$} & N/A & \multicolumn{2}{|c|}{$6.89-7.30$} & N/A & \multicolumn{2}{|c|}{$7.74-8.38$} & N/A & \multicolumn{2}{|c|}{$6.65-7.08$} \\
\hline & Specific Conductance & \multicolumn{2}{|c|}{$2010-4040$} & N/A & \multicolumn{2}{|c|}{$3380-4610$} & N/A & \multicolumn{2}{|c|}{$2040-2840$} & N/A & 820 & 1080 & N/A & 1020 & -3200 \\
\hline & Temperature $\left({ }^{\circ} \mathrm{C}\right)$ & 13.1 & -18.4 & N/A & 13. & -15.1 & N/A & 12. & 16.2 & N/A & 13.2 & -16.8 & N/A & 15.9 & -17.7 \\
\hline & TOX $(\mu \mathrm{g} / \mathrm{L})$ & & $\mathrm{D}$ & N/A & & $\mathrm{D}$ & N/A & & & N/A & & & N/A & $\mathrm{N}$ & $\mathrm{D}$ \\
\hline & TOC $(\mathrm{mg} / \mathrm{L})$ & 2.7 & -21 & N/A & & -16 & N/A & & & N/A & 3.0 & -27 & N/A & 3.2 & \\
\hline
\end{tabular}

Specific conductance unit $=\mu \mathrm{mhos} / \mathrm{cm} @ 25^{\circ} \mathrm{C} ; \mathrm{ND}=$ Not Detected; NS = Not Sampled; N/A = Not applicable; TOX = total organic halogens; TOC = total organic carbon 
Table 10. NETL-PGH 2001 Groundwater Detection Monitoring Program

Results of Analysis - Groundwater Samples, Main Plateau - Contamination Indicator Constituents

(continued)

\begin{tabular}{|c|c|c|c|c|c|c|c|c|c|c|c|c|c|c|c|c|}
\hline \multirow[b]{3}{*}{ Well } & \multirow{3}{*}{\begin{tabular}{|l|} 
Constituents \\
Sample Event \\
\end{tabular}} & \multicolumn{15}{|c|}{ Well } \\
\hline & & \multicolumn{2}{|c|}{ MPW-7D } & \multicolumn{2}{|c|}{ MPW-8 } & \multirow{2}{*}{$\begin{array}{l}\text { MPW-8-1 } \\
\text { Round 1 } \\
\end{array}$} & \multicolumn{2}{|c|}{ MPW-9 } & \multicolumn{2}{|c|}{ MPW-10 } & \multicolumn{2}{|c|}{ MPW-11 } & \multirow{2}{*}{$\begin{array}{c}\text { MPW-11-1 } \\
\text { Round 2 } \\
\end{array}$} & \multicolumn{2}{|c|}{ MPW-12 } & \multirow{2}{*}{$\begin{array}{c}\text { MPW-12- } \\
1 \\
\text { Round 2 }\end{array}$} \\
\hline & & Round 1 & Round 2 & Round 1 & Round 2 & & Round 1 & \begin{tabular}{|l|} 
Round 2 \\
\end{tabular} & Round 1 & Round 2 & Round 1 & Round 2 & & Round 1 & Round 2 & \\
\hline \multirow{6}{*}{ Week 1} & \begin{tabular}{|r|} 
Sample Date \\
\end{tabular} & 05/07/01 & 08/07/01 & 05/09/01 & $08 / 07 / 01$ & N/A & 05/07/01 & 08/07/01 & 05/07/01 & 08/07/01 & 05/08/01 & 08/07/01 & $\mathrm{N} / \mathrm{A}$ & 05/08/01 & $08 / 07 / 01$ & N/A \\
\hline & $\mathrm{pH}$ (standard units) & 7.25 & NS & 7.17 & 6.64 & N/A & 7.30 & 7.71 & 8.67 & 8.97 & 7.00 & 7.09 & N/A & 6.66 & NS & N/A \\
\hline & Specific Conductance & 2150 & NS & 4080 & 3650 & N/A & 860 & 690 & 800 & 630 & 2880 & 2500 & N/A & 4630 & NS & N/A \\
\hline & Temperature $\left({ }^{\circ} \mathrm{C}\right)$ & 19.1 & NS & 17.3 & 20.7 & N/A & 13.7 & 14.5 & 13.9 & 13.8 & 15.8 & 17.3 & N/A & 14.5 & NS & N/A \\
\hline & TOX $(\mu \mathrm{g} / \mathrm{L})$ & ND & NS & ND & ND & N/A & ND & ND & $\mathrm{ND}$ & ND & ND & ND & N/A & ND & NS & N/A \\
\hline & $\mathrm{TOC}(\mathrm{mg} / \mathrm{L})$ & 2.6 & NS & 3.2 & 2.8 & N/A & 3.5 & 3.8 & 1.9 & 1.1 & 1.8 & 2.3 & N/A & 1.6 & NS & $\mathrm{N} / \mathrm{A}$ \\
\hline \multirow{6}{*}{ Week 2} & $\begin{array}{r}\text { Sample Date } \\
\end{array}$ & $05 / 24 / 01$ & 09/06/01 & $05 / 25 / 01$ & $09 / 06 / 01$ & N/A & $05 / 24 / 01$ & 09/06/01 & $05 / 24 / 01$ & 09/06/01 & $05 / 25 / 01$ & $09 / 06 / 01$ & $09 / 06 / 11$ & $05 / 25 / 01$ & $09 / 06 / 01$ & $05 / 25 / 01$ \\
\hline & $\mathrm{pH}$ (standard units) & 7.12 & NS & 7.18 & 6.86 & N/A & 7.43 & 7.41 & 8.92 & 8.82 & 6.91 & 7.10 & 7.10 & 6.91 & NS & 6.91 \\
\hline & Specific Conductance & 1820 & NS & 4020 & 4480 & N/A & 820 & 810 & 740 & 760 & 3180 & 2860 & 2860 & 5370 & NS & 5370 \\
\hline & Temperature $\left({ }^{\circ} \mathrm{C}\right)$ & 17.0 & NS & 17.3 & 19.0 & N/A & 12.3 & 13.0 & 12.7 & 12.8 & 15.9 & 16.8 & 16.8 & 15.1 & NS & 15.1 \\
\hline & TOX $(\mu \mathrm{g} / \mathrm{L})$ & ND & NS & ND & ND & N/A & $\mathrm{ND}$ & ND & ND & ND & $\mathrm{ND}$ & $\mathrm{ND}$ & ND & ND & NS & ND \\
\hline & TOC $(\mathrm{mg} / \mathrm{L})$ & 3.6 & NS & 3.1 & 7.5 & N/A & 3.6 & 9.0 & 2.1 & 11 & 1.4 & 4.8 & 5.3 & 1.7 & NS & 1.3 \\
\hline \multirow{6}{*}{ Week 3} & Sample Date & $06 / 21 / 01$ & $10 / 02 / 01$ & $06 / 21 / 01$ & $10 / 02 / 01$ & $\mathrm{~N} / \mathrm{A}$ & $06 / 21 / 01$ & $10 / 02 / 01$ & $06 / 21 / 01$ & $10 / 02 / 01$ & $06 / 21 / 01$ & $10 / 02 / 01$ & N/A & $06 / 21 / 01$ & $10 / 02 / 01$ & $\mathrm{~N} / \mathrm{A}$ \\
\hline & $\mathrm{pH}$ (standard units) & NS & NS & 7.05 & 6.95 & N/A & 7.36 & 7.35 & 8.83 & 8.82 & 7.03 & 7.09 & N/A & NS & NS & N/A \\
\hline & Specific Conductance & NS & NS & 3770 & 5050 & N/A & 790 & 890 & 700 & 840 & 2880 & 3110 & N/A & NS & NS & N/A \\
\hline & Temperature $\left({ }^{\circ} \mathrm{C}\right)$ & NS & NS & 19.0 & 20.8 & N/A & 14.0 & 14.4 & 13.5 & 13.6 & 17.7 & 17.4 & N/A & NS & NS & N/A \\
\hline & TOX $(\mu \mathrm{g} / \mathrm{L})$ & NS & NS & ND & $\mathrm{ND}$ & N/A & ND & ND & $\mathrm{ND}$ & ND & ND & $\mathrm{ND}$ & N/A & NS & NS & N/A \\
\hline & TOC $(\mathrm{mg} / \mathrm{L})$ & NS & NS & 2.5 & 16 & N/A & 3.5 & 21 & 2.6 & 19 & 1.4 & 10 & N/A & NS & NS & N/A \\
\hline \multirow{6}{*}{ Week 4} & Sample Date & 07/25/01 & $11 / 15 / 01$ & $07 / 25 / 01$ & $11 / 15 / 01$ & $07 / 25 / 01$ & 07/25/01 & $11 / 15 / 01$ & $07 / 25 / 01$ & $11 / 15 / 01$ & 07/25/01 & $11 / 15 / 01$ & N/A & $07 / 25 / 01$ & $11 / 15 / 01$ & N/A \\
\hline & pH (standard units) & NS & NS & 6.99 & 6.86 & 6.99 & 7.27 & 7.52 & 8.66 & 8.63 & 6.82 & 7.05 & N/A & NS & NS & N/A \\
\hline & Specific Conductance & NS & NS & 3650 & 4380 & 3650 & 690 & 770 & 630 & 750 & 2500 & 2650 & N/A & NS & NS & N/A \\
\hline & Temperature $\left({ }^{\circ} \mathrm{C}\right)$ & NS & NS & 19.8 & 18.8 & 19.8 & 14.6 & 12.8 & 14.2 & 12.9 & 17.3 & 16.3 & N/A & NS & NS & N/A \\
\hline & TOX $(\mu \mathrm{g} / \mathrm{L})$ & NS & NS & ND & ND & ND & ND & ND & ND & ND & ND & ND & N/A & NS & NS & N/A \\
\hline & TOC $(\mathrm{mg} / \mathrm{L})$ & NS & NS & 2.3 & 20 & 2.4 & 4.0 & 24 & 3.0 & 26 & 2.5 & 12 & N/A & NS & NS & N/A \\
\hline \multirow{5}{*}{2001 Range } & $\mathrm{pH}$ (standard units) & \multicolumn{2}{|c|}{$7.12-7.25$} & \multicolumn{2}{|c|}{$6.64-7.18$} & N/A & \multicolumn{2}{|c|}{$7.27-7.71$} & \multicolumn{2}{|c|}{$8.63-8.97$} & \multicolumn{2}{|c|}{$6.82-7.10$} & N/A & \multicolumn{2}{|c|}{$6.66-6.91$} & N/A \\
\hline & Specific Conductance & \multicolumn{2}{|c|}{$1820-2150$} & \multicolumn{2}{|c|}{$3650-5050$} & N/A & 690 & -890 & 630 & -840 & 2500 & -3180 & N/A & $4630-$ & -5370 & N/A \\
\hline & Temperature $\left({ }^{\circ} \mathrm{C}\right)$ & 17.0 & -19.1 & 17.3 & 20.8 & N/A & 12.3 & -14.6 & 12.7 & -14.2 & 15.8 & -17.7 & N/A & 14.5 & -15.1 & N/A \\
\hline & TOX $(\mu \mathrm{g} / \mathrm{L})$ & $\mathrm{N}$ & & $\mathrm{N}$ & & N/A & $\mathrm{N}$ & $\mathrm{D}$ & $\mathrm{N}$ & D & $\mathrm{N}$ & $\mathrm{D}$ & N/A & $\mathrm{N}$ & & N/A \\
\hline & $\mathrm{TOC}(\mathrm{mg} / \mathrm{L})$ & $2.6-$ & -3.6 & 2.3 & & N/A & 3.5 & & 1.1 & -26 & 1.4 & -12 & N/A & 1.6 & -1.7 & N/A \\
\hline
\end{tabular}


Table 11. NETL-PGH 2001 Groundwater Detection Monitoring Program Results of Analysis - Groundwater Samples, Valley Fill - Contamination Indicator Constituents

\begin{tabular}{|c|c|c|c|c|c|c|c|c|c|c|c|c|c|c|c|c|c|}
\hline \multirow[b]{3}{*}{ Week } & \multirow{3}{*}{\begin{tabular}{|l|} 
Constituent \\
Sample Event \\
\end{tabular}} & \multicolumn{16}{|c|}{ Well } \\
\hline & & \multicolumn{2}{|c|}{ VFW-1 } & \multicolumn{2}{|c|}{ VFW-2 } & \multirow{2}{*}{$\begin{array}{c}\text { VFW-2- } \\
1 \\
\text { Round } 2\end{array}$} & \multicolumn{2}{|c|}{ VFW-3 } & \multicolumn{2}{|c|}{ VFW-4 } & \multirow{2}{*}{\begin{tabular}{c|} 
VFW-4- \\
1 \\
Round 1
\end{tabular}} & \multicolumn{2}{|c|}{ VFW-5 } & \multirow{2}{*}{$\begin{array}{c}\text { VFW-5- } \\
1 \\
\text { Round 1 } \\
\end{array}$} & \multicolumn{2}{|c|}{ VFW - 6} & \multirow{2}{*}{$\begin{array}{l}\text { VFW-6-1 } \\
\text { Round } 1\end{array}$} \\
\hline & & Round 1 & Round 2 & Round 1 & Round 2 & & Round 1 & Round 2 & Round 1 & Round 2 & & Round 1 & Round 2 & & Round 1 & Round 2 & \\
\hline \multirow{6}{*}{ Week 1} & $\begin{array}{r}\text { Sample Date } \\
\end{array}$ & $05 / 07 / 01$ & $08 / 07 / 01$ & $05 / 07 / 01$ & $08 / 07 / 01$ & N/A & $05 / 09 / 01$ & $08 / 07 / 01$ & 05/07/01 & $08 / 07 / 01$ & N/A & $05 / 07 / 01$ & $08 / 07 / 01$ & 05/07/01 & 05/07/01 & $08 / 07 / 01$ & N/A \\
\hline & $\mathrm{pH}$ (standard units) & 7.95 & 8.15 & 6.89 & 7.23 & N/A & 7.12 & 7.13 & 6.85 & 7.02 & N/A & 7.19 & 7.34 & 7.19 & 7.39 & 7.32 & N/A \\
\hline & Specific Conductance & 920 & 950 & 4580 & 3080 & N/A & 1800 & 2030 & 2240 & 1950 & N/A & 3510 & 1870 & 3510 & 7380 & 4120 & N/A \\
\hline & Temperature $\left({ }^{\circ} \mathrm{C}\right)$ & 13.0 & 15.5 & 11.8 & 18.0 & N/A & 14.5 & 16.5 & 15.0 & 18.7 & N/A & 13.5 & 16.2 & 13.5 & 11.8 & 17.5 & N/A \\
\hline & TOX $(\mu \mathrm{g} / \mathrm{L})$ & ND & $\mathrm{ND}$ & 30 & ND & N/A & $\mathrm{ND}$ & ND & ND & ND & N/A & $\mathrm{ND}$ & $\mathrm{ND}$ & ND & ND & $\mathrm{ND}$ & N/A \\
\hline & TOC $(\mathrm{mg} / \mathrm{L})$ & 3.6 & 7.3 & 3.7 & 1.8 & N/A & 4.0 & 6.4 & ND & 3.7 & $\mathrm{~N} / \mathrm{A}$ & 4.4 & 3.3 & 4.2 & 4.0 & 3.5 & N/A \\
\hline \multirow{6}{*}{ Week 2} & Sample Date & $5 / 24 / 01$ & 09/06/01 & $05 / 24 / 01$ & 09/06/01 & N/A & 05/24/01 & 09/06/01 & $05 / 24 / 01$ & 09/06/01 & N/A & 05/24/01 & 09/06/01 & N/A & $05 / 24 / 01$ & $09 / 06 / 01$ & $05 / 24 / 01$ \\
\hline & pH (standard units) & 8.24 & 8.19 & 6.90 & 6.90 & N/A & 6.98 & 6.87 & 6.92 & 6.78 & $\mathrm{~N} / \mathrm{A}$ & 7.25 & 7.11 & N/A & 7.17 & 7.22 & 7.17 \\
\hline & Specific Conductance & 950 & 1240 & 4940 & 3200 & N/A & 1910 & 2610 & 2220 & 2450 & N/A & 3430 & 3440 & N/A & 6340 & 4890 & 6340 \\
\hline & Temperature $\left({ }^{\circ} \mathrm{C}\right)$ & 13.0 & 14.8 & 12.3 & 15.8 & N/A & 15.7 & 16.0 & 14.9 & 17.0 & $\mathrm{~N} / \mathrm{A}$ & 13.2 & 15.8 & N/A & 12.3 & 16.5 & 12.3 \\
\hline & TOX $(\mu \mathrm{g} / \mathrm{L})$ & $\mathrm{ND}$ & $\mathrm{ND}$ & $\mathrm{ND}$ & $\mathrm{ND}$ & N/A & $\mathrm{ND}$ & $\mathrm{ND}$ & $\mathrm{ND}$ & $\mathrm{ND}$ & N/A & $\mathrm{ND}$ & $\mathrm{ND}$ & N/A & $\mathrm{ND}$ & $\mathrm{ND}$ & $\mathrm{ND}$ \\
\hline & TOC $(\mathrm{mg} / \mathrm{L})$ & 3.2 & 16 & 3.2 & 7.2 & N/A & 3.9 & 13 & 1.8 & 14 & N/A & 4.9 & 9.6 & N/A & 3.7 & 6.0 & 3.2 \\
\hline \multirow{6}{*}{ Week 3} & Sample Date & $06 / 21 / 01$ & $10 / 02 / 01$ & $06 / 21 / 01$ & $10 / 03 / 01$ & N/A & $06 / 22 / 01$ & $10 / 02 / 01$ & $06 / 22 / 01$ & $10 / 02 / 01$ & $06 / 22 / 01$ & $06 / 22 / 01$ & $10 / 03 / 01$ & N/A & $06 / 22 / 01$ & $10 / 03 / 01$ & N/A \\
\hline & pH (standard units) & 7.89 & 8.18 & 6.85 & 6.98 & N/A & 7.24 & 6.81 & 6.81 & 6.74 & 6.81 & 7.10 & 6.85 & N/A & 7.22 & $\begin{array}{c}7 . \\
36 \\
\end{array}$ & N/A \\
\hline & Specific Conductance & 940 & 1230 & 4280 & 2950 & N/A & 1870 & 2930 & 2050 & 2720 & 2050 & 2930 & 3460 & N/A & 4860 & 5000 & N/A \\
\hline & Temperature $\left({ }^{\circ} \mathrm{C}\right)$ & 15.0 & 14.2 & 14.5 & 11.5 & N/A & 15.4 & 16.5 & 15.4 & 16.4 & 15.4 & 13.4 & 14.4 & N/A & 13.2 & 16.2 & N/A \\
\hline & TOX $(\mu \mathrm{g} / \mathrm{L})$ & ND & $\mathrm{ND}$ & $\mathrm{ND}$ & $\mathrm{ND}$ & N/A & $\mathrm{ND}$ & $\mathrm{ND}$ & $\mathrm{ND}$ & $\mathrm{ND}$ & $\mathrm{ND}$ & $\mathrm{ND}$ & $\mathrm{ND}$ & N/A & $\mathrm{ND}$ & $\mathrm{ND}$ & N/A \\
\hline & TOC $(\mathrm{mg} / \mathrm{L})$ & 5.4 & 49 & 2.5 & 25 & N/A & 16 & 25 & 25 & 30 & 24 & 19 & 26 & N/A & 7.0 & 7.9 & N/A \\
\hline \multirow{6}{*}{ Week 4} & Sample Date & $07 / 25 / 01$ & $11 / 15 / 01$ & 07/25/01 & $11 / 15 / 01$ & $11 / 15 / 01$ & 07/25/01 & $11 / 15 / 01$ & $07 / 25 / 01$ & $11 / 15 / 01$ & N/A & 07/25/01 & $11 / 15 / 01$ & N/A & $07 / 25 / 01$ & $11 / 15 / 01$ & N/A \\
\hline & $\mathrm{pH}$ (standard units) & 7.87 & 7.87 & 6.96 & 6.96 & 6.96 & 6.95 & 6.83 & 6.89 & 6.84 & N/A & 7.16 & 6.91 & N/A & 7.23 & 7.32 & N/A \\
\hline & Specific Conductance & 950 & 900 & 3080 & 2480 & 2480 & 2030 & 2730 & 1950 & 2390 & N/A & 1870 & 3380 & N/A & 4120 & 4330 & N/A \\
\hline & Temperature $\left({ }^{\circ} \mathrm{C}\right)$ & 14.8 & 13.5 & 15.5 & 14.6 & 14.6 & 16.3 & 15.5 & 17.1 & 16.3 & N/A & 14.8 & 14.1 & N/A & 16.0 & 14.9 & N/A \\
\hline & $\mathrm{TOX}(\mu \mathrm{g} / \mathrm{L})$ & ND & ND & ND & ND & ND & ND & ND & ND & ND & N/A & ND & ND & N/A & ND & ND & N/A \\
\hline & $\mathrm{TOC}(\mathrm{mg} / \mathrm{L})$ & 4.6 & 48 & 3.0 & 23 & 24 & 4.5 & 41 & 2.5 & 30 & N/A & 5.3 & 27 & N/A & 3.8 & 8.6 & $\mathrm{~N} / \mathrm{A}$ \\
\hline \multirow[b]{2}{*}{2001} & $\mathrm{pH}$ (standard units) & \multicolumn{2}{|c|}{$7.87-8.24$} & \multicolumn{2}{|c|}{$6.85-7.23$} & N/A & \multicolumn{2}{|c|}{$6.83-7.24$} & \multicolumn{2}{|c|}{$6.74-7.02$} & N/A & \multicolumn{2}{|c|}{$6.91-7.34$} & N/A & \multicolumn{2}{|c|}{$7.17-7.39$} & $\mathrm{~N} / \mathrm{A}$ \\
\hline & Specific Conductance & \multicolumn{2}{|c|}{$900-1240$} & \multicolumn{2}{|c|}{$2480-4940$} & N/A & 1800 & -2930 & $1950-$ & -2720 & N/A & 1870 & 3510 & N/A & $4120-$ & 7380 & N/A \\
\hline
\end{tabular}




\begin{tabular}{|c|c|c|c|c|c|c|c|c|c|c|}
\hline Temperature $\left({ }^{\circ} \mathrm{C}\right)$ & $13.0-15.5$ & $11.5-18.0$ & N/A & $14.5-16.5$ & $14.9-18.7$ & N/A & $13.2-16.2$ & $\mathrm{~N} / \mathrm{A}$ & $11.8-17.5$ & N/A \\
\hline TOX $(\mu \mathrm{g} / \mathrm{L})$ & ND & $\mathrm{ND}-30$ & N/A & $\mathrm{ND}$ & ND & N/A & $\mathrm{ND}$ & N/A & ND & N/A \\
\hline TOC $(\mathrm{mg} / \mathrm{L})$ & $3.2-49$ & $1.8-25$ & N/A & $3.9-41$ & ND - 30 & N/A & $3.3-27$ & N/A & $3.5-8.6$ & N/A \\
\hline
\end{tabular}

Specific conductance unit $=\mu \mathrm{mhos} / \mathrm{cm} @ 25^{\circ} \mathrm{C} ; \mathrm{ND}=$ Not Detected; N/A = not applicable; TOX = total organic halogens; TOC = total organic carbon. 
Table 11. NETL-PGH 2001 Groundwater Detection Monitoring Program

Results of Analysis - Groundwater Samples, Valley Fill - Contamination Indicator Constituents (continued)

\begin{tabular}{|c|c|c|c|c|c|c|c|c|c|c|c|c|c|c|c|c|c|}
\hline \multirow[b]{3}{*}{ Week } & \multirow{3}{*}{\begin{tabular}{|l} 
Constituents \\
\\
Sample Event
\end{tabular}} & \multicolumn{16}{|c|}{ Well } \\
\hline & & \multicolumn{2}{|c|}{ VFW-7 } & \multirow{2}{*}{$\begin{array}{c}\text { VFW-7- } \\
1 \\
\text { Round } 2\end{array}$} & \multicolumn{2}{|c|}{ VFW-9 } & \multicolumn{2}{|c|}{ VFW-10 } & \multirow{2}{*}{$\begin{array}{c}\text { VFW-10- } \\
1 \\
\text { Round } 1\end{array}$} & \multicolumn{2}{|c|}{ VFW-11 } & \multirow{2}{*}{$\begin{array}{c}\text { VFW-11- } \\
1 \\
\text { Round } 2\end{array}$} & \multicolumn{2}{|c|}{ VFW-12 } & \multicolumn{2}{|c|}{ VFW-14 } & \multirow{2}{*}{$\begin{array}{c}\text { VFW-14- } \\
\frac{1}{\text { Round } 1}\end{array}$} \\
\hline & & Round 1 & Round 2 & & Round 1 & Round 2 & Round 1 & Round 2 & & Round 1 & Round 2 & & Round 1 & Round 2 & Round 1 & Round 2 & \\
\hline \multirow{6}{*}{ Week 1} & Sample Date & 05/08/01 & 08/07/01 & 08/07/01 & 05/08/01 & 08/07/01 & 05/09/01 & 08/07/01 & N/A & 05/08/01 & $08 / 07 / 01$ & N/A & 05/08/01 & 08/07/01 & 05/07/01 & 08/07/01 & $05 / 07 / 01$ \\
\hline & $\mathrm{pH}$ (standard units) & 6.81 & 7.02 & 7.02 & 7.27 & NS & 6.97 & 7.07 & N/A & 7.28 & 7.26 & N/A & 6.98 & 7.14 & 7.03 & 7.06 & 7.03 \\
\hline & Specific Conductance & 3950 & 3900 & 3900 & 1250 & NS & 2280 & 2260 & N/A & 1800 & 1800 & N/A & 2090 & 2130 & 2740 & 2510 & 2740 \\
\hline & Temperature $\left({ }^{0} \mathrm{C}\right)$ & 12.3 & 16.2 & 16.2 & 10.2 & NS & 11.9 & 16.0 & N/A & 11.7 & 14.5 & N/A & 11.0 & 14.8 & 12.8 & 16.7 & 12.8 \\
\hline & TOX $(\mu \mathrm{g} / \mathrm{L})$ & ND & ND & ND & ND & NS & ND & ND & N/A & ND & ND & N/A & ND & ND & ND & ND & ND \\
\hline & TOC (mg/L) & 4.0 & ND & 1.5 & 1.9 & NS & 5.8 & 2.4 & N/A & 3.1 & 2.0 & N/A & 8.7 & 6.5 & 2.6 & 34 & 2.9 \\
\hline \multirow{6}{*}{ Week 2} & Sample Date & $05 / 24 / 01$ & 09/06/01 & N/A & $05 / 24 / 01$ & $09 / 06 / 01$ & $05 / 24 / 01$ & $09 / 06 / 01$ & N/A & $05 / 24 / 01$ & $09 / 06 / 01$ & $09 / 06 / 01$ & $05 / 24 / 01$ & 09/06/01 & $05 / 24 / 01$ & $09 / 06 / 01$ & N/A \\
\hline & $\mathrm{pH}$ (standard units) & 6.97 & 6.79 & N/A & 6.90 & NS & 7.02 & 6.80 & N/A & 7.30 & 7.00 & 7.00 & 7.09 & 6.88 & 6.97 & 6.84 & N/A \\
\hline & Specific Conductance & 4190 & 4730 & N/A & 750 & NS & 2390 & 2860 & N/A & 1850 & 2230 & 2230 & 2230 & 2850 & 2830 & 2920 & N/A \\
\hline & Temperature $\left({ }^{\circ} \mathrm{C}\right)$ & 12.5 & 14.2 & N/A & 10.5 & NS & 12.2 & 15.1 & N/A & 12.5 & 13.5 & 13.5 & 12.0 & 13.9 & 12.8 & 15.4 & N/A \\
\hline & TOX $(\mu \mathrm{g} / \mathrm{L})$ & ND & ND & N/A & ND & NS & ND & ND & N/A & ND & ND & ND & ND & ND & ND & ND & N/A \\
\hline & TOC (mg/L) & 4.1 & 11 & N/A & 2.4 & NS & 2.6 & 11 & N/A & 2.0 & 6.0 & 7.3 & 5.7 & 15 & 3.3 & 9.0 & N/A \\
\hline \multirow{6}{*}{ Week 3} & Sample Date & $06 / 22 / 08$ & $10 / 03 / 01$ & N/A & $06 / 22 / 01$ & 10/03/01 & 06/22/01 & $10 / 03 / 01$ & N/A & $06 / 22 / 01$ & $10 / 03 / 01$ & $10 / 03 / 01$ & $06 / 22 / 01$ & $10 / 03 / 01$ & $06 / 22 / 01$ & $10 / 03 / 01$ & N/A \\
\hline & $\mathrm{pH}$ (standard units) & 6.84 & 6.93 & N/A & NS & NS & 6.90 & 6.89 & N/A & 7.14 & 7.15 & 7.15 & 7.00 & 6.92 & 6.86 & 6.74 & N/A \\
\hline & Specific Conductance & 3960 & 4660 & N/A & NS & NS & 2230 & 3040 & N/A & 1760 & 2310 & 2310 & 2080 & 2910 & 2570 & 2980 & N/A \\
\hline & Temperature $\left({ }^{0} \mathrm{C}\right)$ & 13.2 & 13.3 & N/A & NS & NS & 12.9 & 14.4 & N/A & 12.7 & 13.0 & 13.0 & 12.4 & 13.8 & 13.0 & 15.0 & N/A \\
\hline & TOX $(\mu \mathrm{g} / \mathrm{L})$ & ND & ND & N/A & NS & NS & $\mathrm{ND}$ & ND & N/A & ND & $\mathrm{ND}$ & ND & $\mathrm{ND}$ & ND & $\mathrm{ND}$ & ND & $\mathrm{N} / \mathrm{A}$ \\
\hline & TOC (mg/L) & 16 & 21 & N/A & NS & NS & 16 & 24 & N/A & 9.5 & 16 & 17 & 19 & 50 & 20 & 36 & N/A \\
\hline \multirow{6}{*}{ Week 4} & Sample Date & $07 / 25 / 01$ & $11 / 15 / 01$ & N/A & $07 / 25 / 01$ & $11 / 15 / 01$ & 07/25/01 & $11 / 15 / 01$ & $07 / 25 / 01$ & $07 / 25 / 01$ & $11 / 15 / 01$ & N/A & $07 / 25 / 01$ & $11 / 15 / 01$ & $07 / 25 / 01$ & $11 / 15 / 01$ & N/A \\
\hline & $\mathrm{pH}$ (standard units) & 6.89 & 6.87 & N/A & NS & NS & 6.95 & 6.95 & 6.95 & 7.07 & 7.10 & N/A & 6.98 & 7.02 & 7.00 & 6.72 & N/A \\
\hline & Specific Conductance & 3900 & 2480 & N/A & NS & NS & 2180 & 3290 & 2180 & 1750 & 2080 & N/A & 2060 & 2450 & 2480 & 2870 & N/A \\
\hline & Temperature $\left({ }^{\circ} \mathrm{C}\right)$ & 15.5 & 13.7 & N/A & NS & NS & 14.4 & 14.8 & 14.4 & 14.6 & 13.8 & N/A & 14.0 & 14.0 & 15.0 & 14.8 & N/A \\
\hline & TOX $(\mu \mathrm{g} / \mathrm{L})$ & ND & $\mathrm{ND}$ & N/A & NS & NS & $\mathrm{ND}$ & $\mathrm{ND}$ & ND & ND & ND & N/A & ND & ND & $\mathrm{ND}$ & $\mathrm{ND}$ & N/A \\
\hline & TOC (mg/L) & 4.0 & 21 & N/A & NS & NS & 3.8 & 22 & 3.3 & 2.0 & 26 & N/A & 6.5 & 33 & 2.6 & 28 & $\mathrm{~N} / \mathrm{A}$ \\
\hline \multirow{5}{*}{$\begin{array}{l}2001 \\
\text { Range }\end{array}$} & $\mathrm{pH}$ (standard unit) & \multicolumn{2}{|c|}{$6.79-7.02$} & N/A & \multicolumn{2}{|c|}{$6.90-7.27$} & \multicolumn{2}{|c|}{$6.80-7.07$} & N/A & \multicolumn{2}{|c|}{$7.00-7.30$} & N/A & \multicolumn{2}{|c|}{$6.88-7.14$} & \multicolumn{2}{|c|}{$6.72-7.06$} & N/A \\
\hline & Specific Conductance & 2480 & -4730 & N/A & $750-$ & 1250 & 2180 & 3290 & N/A & 1750 & 2310 & N/A & 2060 & 2910 & 2480 & 2980 & N/A \\
\hline & Temperature $\left({ }^{\circ} \mathrm{C}\right)$ & 12.3 & -16.2 & N/A & 10.2 & 10.5 & 11.9 & 16.0 & N/A & 11.7 & 14.6 & N/A & 11.0 & 14.8 & 12.8 & 16.7 & N/A \\
\hline & TOX $(\mu \mathrm{g} / \mathrm{L})$ & $\mathrm{N}$ & $\mathrm{D}$ & N/A & $\mathrm{N}$ & $\mathrm{D}$ & & & N/A & & & N/A & $\mathrm{N}$ & $\mathrm{D}$ & $\mathrm{N}$ & & N/A \\
\hline & TOC (mg/L) & $\mathrm{ND}$ & -21 & N/A & 1.9. & 2.4 & 2.4 & & N/A & 2.0 & & N/A & 5.7 & & & 36 & N/A \\
\hline
\end{tabular}


Table 12. NETL-PGH 2001 Groundwater Detection Monitoring Program

Results of Analysis - Groundwater Samples, Main Plateau - Groundwater Characteristics Constituents

\begin{tabular}{|c|c|c|c|c|c|c|c|c|c|c|c|c|}
\hline \multirow{3}{*}{$\begin{array}{l}\text { Constituent } \\
\text { Sampling Date }\end{array}$} & \multicolumn{12}{|c|}{ Well Number and Sample Date } \\
\hline & \multicolumn{2}{|c|}{ MPW-1 } & \multicolumn{2}{|c|}{ MPW-2 } & \multicolumn{2}{|c|}{ MPW-4 } & \multirow{2}{*}{$\begin{array}{c}\text { MPW-4-1 } \\
05 / 08 / 01\end{array}$} & \multicolumn{2}{|c|}{ MPW-4D } & \multirow{2}{*}{$\begin{array}{c}\text { MPW-4D- } \\
1 \\
10 / 2-4 / 01\end{array}$} & \multicolumn{2}{|c|}{ MPW-7 } \\
\hline & 05/09/01 & $10 / 2-4 / 01$ & 05/08/01 & $10 / 2-4 / 01$ & 05/08/01 & $10 / 2-4 / 01$ & & 05/08/01 & $10 / 2-4 / 01$ & & $05 / 7-24 / 01$ & $\begin{array}{l}10 / 2-4 / 02 \\
11 / 15 / 02 \\
\end{array}$ \\
\hline \multicolumn{13}{|c|}{ Inorganics $(\mu \mathrm{g} / \mathrm{L})$} \\
\hline Aluminum & $\mathrm{ND}$ & $\mathrm{ND}$ & ND & ND & $\mathrm{ND}$ & ND & ND & ND & ND & ND & ND & $\mathrm{ND}$ \\
\hline Boron & ND & ND & ND & ND & ND & ND & ND & ND & ND & ND & ND & ND \\
\hline Calcium & 340000 & NS & 420000 & NS & 240000 & NS & 240000 & 4400 & 4600 & 4500 & 250000 & 110000 \\
\hline Iron & ND & NS & ND & NS & 250 & NS & ND & ND & NS & NS & ND & ND \\
\hline Magnesium & 190000 & 200000 & 96000 & 99000 & 92000 & 94000 & 91000 & 790 & 890 & 860 & 36000 & 14000 \\
\hline Manganese & 72 & 46 & 1500 & 1600 & 490 & 340 & 400 & 27 & 15 & 15 & 530 & 61 \\
\hline Nickel & 750 & 630 & $\mathrm{ND}$ & $\mathrm{ND}$ & 590 & 610 & 500 & ND & ND & ND & 2300 & 570 \\
\hline Phosphorus & ND & 59 & 130 & 23 & ND & ND & 27 & ND & ND & NS & 77 & ND \\
\hline Potassium & 3700 & 6100 & 3300 & 4100 & 5800 & 4200 & 6900 & ND & ND & ND & 5400 & 3100 \\
\hline Silicon & 3500 & 3700 & 4100 & 4000 & 4000 & 4200 & 3900 & 4000 & 3900 & 3900 & 4600 & 5200 \\
\hline Sodium & 110000 & NS & 230000 & NS & 98000 & NS & 100000 & 230000 & NS & NS & 320000 & NS \\
\hline Strontium & 1500 & 1200 & 860 & 680 & 960 & 780 & 850 & 150 & 130 & 120 & 760 & 190 \\
\hline \multicolumn{13}{|c|}{ Quality Parameters (mg/L) } \\
\hline Chloride & 24 & 1100 & 19 & 1300 & 20 & 540 & N/A & 12 & 110 & N/A & 120 & 150 \\
\hline Fluoride & 0.15 & 0.12 & 0.58 & 0.066 & 0.22 & 0.15 & N/A & 1.9 & 1.6 & N/A & 0.23 & 0.17 \\
\hline Nitrate & 0.20 & 0.23 & 0.74 & 0.72 & 0.47 & 0.12 & N/A & ND & 0.34 & $\mathrm{~N} / \mathrm{A}$ & 1.0 & 0.74 \\
\hline Sulfate & 220 & 240 & 150 & 160 & 130 & 150 & N/A & 21 & 22 & $\mathrm{~N} / \mathrm{A}$ & 220 & 95 \\
\hline Total Dissolved Solids & 3100 & NS & 2200 & NS & 1700 & NS & N/A & 590 & NS & N/A & NS & NS \\
\hline Total Alkalinity (Bicarbonate) & 200 & 220 & 160 & 160 & 220 & 220 & N/A & 360 & 340 & N/A & 120 & 220 \\
\hline Total Alkalinity (Carbonate) & $\mathrm{ND}$ & $\mathrm{ND}$ & $\mathrm{ND}$ & $\mathrm{ND}$ & $\mathrm{ND}$ & $\mathrm{ND}$ & N/A & $\mathrm{ND}$ & ND & N/A & ND & ND \\
\hline
\end{tabular}

$\mathrm{N} / \mathrm{A}=$ not applicable; $\mathrm{NS}=$ not sampled; $\mathrm{ND}=$ not detected

Exceeded Pennsylvania Secondary Drinking Water MCL

Exceeded Pennsylvania Secondary Drinking Water MCL and Act 2 Secondary Maximum Contaminant Level

Exceeded Pennsylvania Secondary Drinking Water MCL, Act 2 Secondary Maximum Contaminant Level, and EPA Region III Risk Based Table 
Table 12. NETL-PGH 2001 Groundwater Detection Monitoring Program

Results of Analysis - Groundwater Samples, Main Plateau - Groundwater Characteristics Constituents

(continued)

\begin{tabular}{|c|c|c|c|c|c|c|c|c|c|c|c|c|c|c|}
\hline \multirow{3}{*}{ Constituent } & \multicolumn{14}{|c|}{ Well Number and Sample Date } \\
\hline & \multicolumn{2}{|c|}{ MPW-7D } & \multicolumn{2}{|c|}{ MPW-8 } & \multicolumn{2}{|c|}{ MPW-9 } & \multicolumn{2}{|c|}{ MPW-10 } & \multirow{2}{*}{$\begin{array}{c}\text { MPW-10- } \\
1 \\
05 / 07 / 01\end{array}$} & \multicolumn{2}{|c|}{ MPW-11 } & \multirow{2}{*}{$\begin{array}{c}\text { MPW-11- } \\
1 \\
05 / 08 / 01\end{array}$} & \multicolumn{2}{|c|}{ MPW-12 } \\
\hline & $05 / 07 / 01$ & $10 / 2-4 / 01$ & 05/09/01 & $\begin{array}{l}10 / 2-4 / 01 \\
11 / 15 / 01\end{array}$ & 05/07/01 & $10 / 2-4 / 01$ & 05/07/01 & $10 / 2-4 / 01$ & & 05/08/01 & $10 / 2-4 / 01$ & & 05/08/01 & $10 / 2-4 / 01$ \\
\hline \multicolumn{15}{|l|}{ Inorganics $(\mu \mathrm{g} / \mathrm{L})$} \\
\hline Aluminum & ND & NS & $\mathrm{ND}$ & ND & $\mathrm{ND}$ & ND & ND & ND & N/A & ND & ND & N/A & ND & NS \\
\hline Boron & ND & NS & $\mathrm{ND}$ & ND & ND & ND & ND & ND & $\mathrm{N} / \mathrm{A}$ & ND & $\mathrm{ND}$ & $\mathrm{N} / \mathrm{A}$ & ND & NS \\
\hline Calcium & 210000 & NS & 400000 & NS & 68000 & 67000 & 2500 & 2000 & N/A & 300000 & 250000 & $\mathrm{~N} / \mathrm{A}$ & 690000 & NS \\
\hline Iron & ND & NS & $\mathrm{ND}$ & NS & $\mathrm{ND}$ & NS & ND & NS & $\mathrm{N} / \mathrm{A}$ & ND & NS & $\mathrm{N} / \mathrm{A}$ & ND & NS \\
\hline Magnesium & 42000 & NS & 110000 & 120000 & 17000 & 17000 & $\mathrm{ND}$ & $\mathrm{ND}$ & N/A & 70000 & 56000 & $\mathrm{~N} / \mathrm{A}$ & 8500 & NS \\
\hline Manganese & 11 & NS & 120 & 39 & 32 & 24 & $\mathrm{ND}$ & $\mathrm{ND}$ & $\mathrm{N} / \mathrm{A}$ & 80 & 41 & N/A & 110 & NS \\
\hline Nickel & 120 & NS & 480 & 270 & 140 & 260 & $\mathrm{ND}$ & $\mathrm{ND}$ & $\mathrm{N} / \mathrm{A}$ & $\mathrm{ND}$ & $\mathrm{ND}$ & $\mathrm{N} / \mathrm{A}$ & ND & NS \\
\hline N/APhosphorus & 20 & NS & 46 & ND & 100 & ND & 32 & $\mathrm{ND}$ & N/A & ND & ND & N/A & $\mathrm{ND}$ & NS \\
\hline Potassium & 2500 & NS & 5400 & 6900 & 1200 & 1300 & $\mathrm{ND}$ & $\mathrm{ND}$ & $\mathrm{N} / \mathrm{A}$ & 4700 & 4900 & $\mathrm{~N} / \mathrm{A}$ & 4700 & NS \\
\hline Silicon & 4600 & NS & 4400 & 4500 & 3800 & 4000 & 4600 & 4100 & N/A & 3600 & 3500 & $\mathrm{~N} / \mathrm{A}$ & 4000 & NS \\
\hline Sodium & 130000 & NS & 280000 & NS & 100000 & NS & 190000 & NS & N/A & 220000 & NS & $\mathrm{N} / \mathrm{A}$ & 590000 & NS \\
\hline Strontium & 1600 & NS & 1100 & 850 & 1700 & 1400 & 930 & 54 & N/A & 750 & 460 & $\mathrm{~N} / \mathrm{A}$ & 1100 & NS \\
\hline \multicolumn{15}{|c|}{ Quality Parameters (mg/L) } \\
\hline Chloride & 110 & NS & 23 & 1100 & 81 & 100 & 55 & 78 & $\mathrm{~N} / \mathrm{A}$ & 18 & 630 & 19 & 20 & NS \\
\hline Fluoride & 0.14 & NS & 0.10 & 0.073 & 0.15 & 0.13 & 0.44 & 0.46 & $\mathrm{~N} / \mathrm{A}$ & 0.18 & 0.19 & 0.079 & 0.091 & NS \\
\hline Nitrate & 0.21 & NS & 0.14 & 0.27 & 0.25 & 0.20 & 0.051 & $\mathrm{ND}$ & 0.059 & 1.0 & 1.6 & $\mathrm{~N} / \mathrm{A}$ & 1.1 & NS \\
\hline Sulfate & 66 & NS & 200 & 190 & 72 & 51 & 15 & 12 & N/A & 220 & 220 & 180 & 220 & NS \\
\hline Total Dissolved Solids & 940 & NS & 3100 & NS & 520 & NS & 490 & NS & $\mathrm{N} / \mathrm{A}$ & 1900 & NS & 1500 & 6400 & NS \\
\hline Total Alkalinity (Bicarbonate) & 260 & NS & 210 & 210 & 230 & 250 & 310 & 290 & $\mathrm{~N} / \mathrm{A}$ & 120 & 120 & 120 & 140 & NS \\
\hline Total Alkalinity (Carbonate) & ND & NS & ND & ND & $\mathrm{ND}$ & $\mathrm{ND}$ & 5.8 & 25 & $\mathrm{~N} / \mathrm{A}$ & ND & $\mathrm{ND}$ & ND & $\mathrm{ND}$ & NS \\
\hline
\end{tabular}

$\mathrm{N} / \mathrm{A}=$ not applicable; $\mathrm{NS}=$ not sampled; $\mathrm{ND}=$ not detected.

Exceeded Pennsylvania Secondary Drinking Water MCL

Exceeded Pennsylvania Secondary Drinking Water MCL and Act 2 Secondary Maximum

Contaminant Level 
Table 13. NETL-PGH 2001 Groundwater Detection Monitoring Program Results of Analysis - Groundwater Samples, Valley Fill - Groundwater Characteristics Constituents

\begin{tabular}{|c|c|c|c|c|c|c|c|c|c|c|c|c|c|c|}
\hline \multirow{3}{*}{$\begin{array}{l}\text { Constituent } \\
\text { Date Sampled }\end{array}$} & \multicolumn{14}{|c|}{ Well Number and Sample Date } \\
\hline & \multicolumn{2}{|c|}{ VFW-1 } & \multirow{2}{*}{\begin{tabular}{|c|} 
VFW-1-1 \\
$05 / 07 / 01$
\end{tabular}} & \multicolumn{2}{|c|}{ VFW-2 } & \multirow{2}{*}{$\begin{array}{c}\text { VFW-2-1 } \\
10 / 02 / 01 \\
\end{array}$} & \multicolumn{2}{|c|}{ VFW-3 } & \multicolumn{2}{|c|}{ VFW-4 } & \multirow{2}{*}{$\begin{array}{c}\text { VFW-4- } \\
1 \\
05 / 07 / 01\end{array}$} & \multicolumn{2}{|c|}{ VFW-5 } & \multirow{2}{*}{$\begin{array}{c}\text { VFW-5-1 } \\
05 / 07 / 01\end{array}$} \\
\hline & 05/7/01 & $10 / 2-4 / 01$ & & 05/07/01 & $10 / 2-4 / 01$ & & $05 / 09 / 01$ & $10 / 2-4 / 01$ & 05/07/01 & $10 / 2-4 / 01$ & & 05/07/01 & $10 / 2-4 / 01$ & \\
\hline \multicolumn{15}{|c|}{ Inorganics $(\mu \mathrm{g} / \mathrm{L})$} \\
\hline Aluminum & ND & ND & N/A & ND & ND & ND & ND & ND & ND & ND & ND & ND & ND & N/A \\
\hline Boron & ND & ND & N/A & ND & ND & ND & ND & ND & ND & ND & ND & $\mathrm{ND}$ & ND & N/A \\
\hline Calcium & 7000 & 4300 & N/A & 610000 & NS & NS & 180000 & $\mathrm{NS}$ & 280000 & NS & 270000 & 330000 & NS & N/A \\
\hline Iron & 270 & NS & N/A & 2500 & NS & NS & ND & $\mathrm{NS}$ & ND & NS & ND & 220 & NS & N/A \\
\hline Magnesium & 2000 & 1200 & N/A & 120000 & 60000 & 68000 & 75000 & 100000 & 97000 & 95000 & 95000 & 46000 & 57000 & N/A \\
\hline Manganese & 44 & $\mathrm{ND}$ & N/A & 2900 & 1500 & 1700 & 22 & 41 & 61 & 38 & 83 & ND & 160 & N/A \\
\hline Nickel & $\mathrm{ND}$ & ND & N/A & $\mathrm{ND}$ & $\mathrm{ND}$ & $\mathrm{ND}$ & 220 & 440 & 160 & 220 & 150 & 49 & $\mathrm{ND}$ & N/A \\
\hline Phosphorus & 88 & 41 & N/A & 60 & ND & $\mathrm{NS}$ & 84 & ND & $\mathrm{ND}$ & $\mathrm{ND}$ & $\mathrm{ND}$ & 110 & ND & N/A \\
\hline Potassium & 1200 & 1200 & N/A & 9900 & 9700 & 8700 & 4000 & 5200 & 3900 & 4100 & 3800 & 6000 & 4900 & N/A \\
\hline Silicon & 5900 & 4500 & N/A & 6700 & 8500 & 9400 & 4100 & 4300 & 5600 & 5200 & 5900 & 11000 & 7100 & N/A \\
\hline Sodium & 240000 & NS & N/A & 200000 & NS & $\mathrm{NS}$ & ND & $\mathrm{NS}$ & 24000 & 24000 & 24000 & 410000 & NS & N/A \\
\hline Strontium & 500 & 230 & N/A & 7000 & 2900 & 2600 & 940 & 960 & 1800 & 860 & 1900 & 840 & 1100 & N/A \\
\hline \multicolumn{15}{|l|}{ Quality Parameters $(\mathrm{mg} / \mathrm{L})$} \\
\hline Chloride & 8.9 & 27 & 9.3 & ND & 360 & N/A & 13 & 600 & $\mathrm{ND}$ & 540 & N/A & 130 & 840 & N/A \\
\hline Fluoride & 1.5 & 1.6 & 1.5 & 0.58 & 1.2 & N/A & 0.24 & 0.22 & 0.49 & 0.16 & N/A & 0.94 & 0.46 & N/A \\
\hline Nitrate & ND & ND & N/A & 0.081 & 0.066 & N/A & 1.5 & 1.2 & 0.12 & 0.068 & N/A & 1.2 & 0.32 & 1.2 \\
\hline Sulfate & 1.7 & 3.0 & N/A & 600 & 880 & N/A & 130 & 150 & 92 & 71 & N/A & 290 & 280 & N/A \\
\hline Total Dissolved Solids & 570 & NS & N/A & 3300 & NS & N/A & 1300 & $\mathrm{NS}$ & 1300 & NS & N/A & 2500 & NS & N/A \\
\hline Total Alkalinity (Bicarbonate) & 510 & 530 & N/A & 170 & 220 & N/A & 250 & 310 & 310 & 320 & N/A & 210 & 260 & N/A \\
\hline Total Alkalinity (Carbonate) & ND & $\mathrm{ND}$ & N/A & ND & ND & N/A & ND & ND & ND & ND & N/A & ND & ND & N/A \\
\hline
\end{tabular}

$\mathrm{N} / \mathrm{A}=$ not applicable; $\mathrm{NS}=$ not sampled; $\mathrm{ND}=$ not detected.

Exceeded Pennsylvania Secondary Drinking Water MCL

Exceeded Pennsylvania Secondary Drinking Water MCL and Act 2 Secondary Maximum Contaminant Level

Exceeded Pennsylvania Secondary Drinking Water MCL, Act 2 Secondary Maximum Contaminant Level, and EPA Region III Risk Based Table 
Table 13. NETL-PGH 2001 Groundwater Detection Monitoring Program

Results of Analysis - Groundwater Samples, Valley Fill - Groundwater Characteristics Constituents

(continued)

\begin{tabular}{|c|c|c|c|c|c|c|c|c|c|c|c|c|c|c|c|c|}
\hline \multirow{3}{*}{$\begin{array}{l}\text { Constituent } \\
\text { Sample Date }\end{array}$} & \multicolumn{16}{|c|}{ Well Number and Sample Date } \\
\hline & \multicolumn{2}{|c|}{ VFW-6 } & \multirow{2}{*}{$\begin{array}{c}\text { VFW-6-1 } \\
10 / 2-4 / 01\end{array}$} & \multicolumn{2}{|c|}{ VFW-7 } & \multirow{2}{*}{$\begin{array}{c}\text { VFW-7- } \\
1\end{array}$} & \multicolumn{2}{|c|}{ VFW 9} & \multicolumn{2}{|c|}{ VFW-10 } & \multicolumn{2}{|c|}{ VFW-11 } & \multicolumn{2}{|c|}{ VFW-12 } & \multicolumn{2}{|c|}{ VFW-14 } \\
\hline & $05 / 07 / 01$ & $\begin{array}{l}10 / 2- \\
4 / 01 \\
\end{array}$ & & $\begin{array}{c}05 / 08 / 0 \\
1 \\
\end{array}$ & $\begin{array}{l}10 / 2- \\
4 / 01 \\
\end{array}$ & & 05/8/01 & $10 / 2-4 / 01$ & $\begin{array}{c}05 / 09 / 0 \\
1 \\
\end{array}$ & $\begin{array}{l}10 / 2- \\
4 / 01 \\
\end{array}$ & $\begin{array}{c}05 / 08 / 0 \\
1 \\
\end{array}$ & $10 / 2-4 / 01$ & $\begin{array}{c}05 / 08 / 0 \\
1 \\
\end{array}$ & $\begin{array}{l}10 / 2- \\
4 / 01 \\
\end{array}$ & 05/07/01 & $\begin{array}{l}10 / 2- \\
4 / 01 \\
\end{array}$ \\
\hline \multicolumn{17}{|c|}{ Inorganics $(\mu \mathrm{g} / \mathrm{L})$} \\
\hline Aluminum & ND & ND & N/A & $\mathrm{ND}$ & $\mathrm{ND}$ & N/A & ND & NS & ND & ND & ND & ND & ND & ND & ND & ND \\
\hline Boron & $\mathrm{ND}$ & ND & N/A & $\mathrm{ND}$ & ND & N/A & $\mathrm{ND}$ & NS & $\mathrm{ND}$ & ND & $\mathrm{ND}$ & ND & 300 & 320 & $\mathrm{ND}$ & ND \\
\hline Calcium & 440000 & NS & N/A & 420000 & NS & N/A & 200000 & NS & 300000 & NS & 240000 & NS & 260000 & NS & 340000 & NS \\
\hline Iron & 1200 & NS & N/A & 3900 & NS & N/A & ND & NS & ND & NS & ND & NS & ND & NS & 570 & NS \\
\hline Magnesium & 76000 & 45000 & N/A & 98000 & 87000 & N/A & 41000 & NS & 64000 & 61000 & 65000 & 64000 & 77000 & 73000 & 73000 & 72000 \\
\hline Manganese & 890 & 600 & N/A & 1700 & 1600 & N/A & 51 & NS & 2900 & 3400 & 24 & 160 & 32 & 180 & 1500 & 3200 \\
\hline Nickel & ND & ND & N/A & $\mathrm{ND}$ & $\mathrm{ND}$ & N/A & 410 & NS & 41 & 46 & 870 & 440 & 770 & 300 & $\mathrm{ND}$ & $\mathrm{ND}$ \\
\hline Phosphorus & 170 & 85 & N/A & $\mathrm{ND}$ & ND & N/A & 95 & NS & 790 & 190 & $\mathrm{ND}$ & $\mathrm{ND}$ & $\mathrm{ND}$ & ND & 93 & 41 \\
\hline Potassium & 16000 & 20000 & N/A & 6100 & 7400 & N/A & 2400 & NS & 6700 & 15000 & 2300 & 2600 & 3700 & 5500 & 4000 & 3900 \\
\hline Silicon & 5200 & 6400 & N/A & 6000 & 5400 & N/A & 3500 & NS & 6700 & 7500 & 3200 & 3700 & 4700 & 6200 & 7200 & 6500 \\
\hline Sodium & 1100000 & NS & N/A & 370000 & NS & N/A & 49000 & NS & 150000 & NS & 68000 & 87000 & 140000 & NS & 220000 & NS \\
\hline Strontium & 2100 & 1100 & N/A & 5100 & 3800 & N/A & 400 & NS & 660 & 670 & 960 & 670 & 2600 & 1500 & 1800 & 1200 \\
\hline \multicolumn{17}{|c|}{ Quality Parameters $(\mathrm{mg} / \mathrm{L})$} \\
\hline Chloride & 260 & 1200 & 1400 & 16 & 1300 & NS & 24 & NS & 21 & 600 & 19 & 500 & 16 & 530 & 110 & 690 \\
\hline Fluoride & 0.96 & 0.96 & NS & ND & 0.095 & 0.081 & 0.30 & NS & 0.53 & 0.72 & 0.12 & 0.10 & 0.44 & 0.44 & 0.28 & 0.18 \\
\hline Nitrate & 0.052 & ND & N/A & ND & ND & ND & 1.3 & NS & 3.8 & 0.37 & 0.077 & 0.13 & ND & 0.76 & 0.062 & ND \\
\hline Sulfate & 400 & 490 & 440 & 120 & 140 & N/A & 180 & NS & 620 & 580 & 150 & 140 & 340 & 270 & 270 & 220 \\
\hline Total Dissolved Solids & 5100 & NS & NS & 3200 & NS & N/A & 1200 & NS & 1800 & NS & 1600 & NS & 1800 & NS & 2200 & NS \\
\hline Alkalinity (Bicarbonate) & 82 & 72 & N/A & 220 & 220 & N/A & 140 & NS & 240 & 240 & 190 & 180 & 290 & 340 & 230 & 260 \\
\hline Alkalinity (Carbonate) & $\mathrm{ND}$ & ND & N/A & $\mathrm{ND}$ & $\mathrm{ND}$ & $\mathrm{N} / \mathrm{A}$ & ND & NS & ND & ND & ND & ND & $\mathrm{ND}$ & $\mathrm{ND}$ & $\mathrm{ND}$ & $\mathrm{ND}$ \\
\hline
\end{tabular}

$\mathrm{N} / \mathrm{A}=$ not applicable; $\mathrm{NS}=$ not sampled; $\mathrm{ND}=$ not detected.

Exceeded Pennsylvania Secondary Drinking Water MCL

Exceeded Pennsylvania Secondary Drinking Water MCL and Act 2 Secondary Maximum Contaminant Level 
Exceeded Pennsylvania Secondary Drinking Water MCL, Act 2 Secondary Maximum Contaminant Level, and EPA Region III Risk Based Table

Exceeded EPA Region III Risk Based Table 
Table 14. NETL-PGH 2001 Groundwater Detection Monitoring Program

Results of Analysis - Groundwater Samples

Main Plateau - Semivolatile Organic Compounds Constituents $(\mu \mathrm{g} / \mathrm{L})$

\begin{tabular}{|c|c|c|c|c|}
\hline \multirow{3}{*}{$\begin{array}{l}\text { Constituent } \\
\text { Sample Date }\end{array}$} & \multicolumn{4}{|c|}{ Well Number and Sample Date } \\
\hline & \multicolumn{2}{|c|}{ MPW-1 } & \multicolumn{2}{|c|}{ MPW-7 } \\
\hline & 05/09/01 & $10 / 03 / 01$ & 05/07/01 & 10/03/01 \\
\hline 1,2,4-Trichlorobenzene & $\mathrm{ND}$ & $\mathrm{ND}$ & ND & ND \\
\hline 1,2-Dichlorobenzene & ND & ND & ND & ND \\
\hline 1,3-Dichlorobenzene & ND & ND & ND & ND \\
\hline 1,4-Dichlorobenzene & ND & $\mathrm{ND}$ & $\mathrm{ND}$ & ND \\
\hline 2,4,5-Trichlorophenol & ND & ND & ND & ND \\
\hline 2,4,6-Trichlorophenol & ND & ND & ND & ND \\
\hline 2,4-Dichlorophenol & ND & ND & ND & ND \\
\hline 2,4-Dimethylphenol & ND & ND & ND & ND \\
\hline 2,4-Dinitrophenol & ND & ND & $\mathrm{ND}$ & ND \\
\hline 2,4-Dinitrotoulene & ND & ND & $\mathrm{ND}$ & ND \\
\hline 2,6-Dinitrotoluene & ND & ND & ND & ND \\
\hline 2-Chloronaphthalene & ND & $\mathrm{ND}$ & ND & ND \\
\hline 2-Chlorophenol & ND & ND & ND & ND \\
\hline 2-Methylnaphthalene & ND & ND & $\mathrm{ND}$ & ND \\
\hline 2-Methylphenol (o-Cresol) & ND & ND & ND & ND \\
\hline 2-Nitroaniline & ND & ND & ND & ND \\
\hline 2-Nitrophenol & ND & $\mathrm{ND}$ & ND & ND \\
\hline 3,3'-Dichlorobenzidine & ND & ND & ND & $\mathrm{ND}$ \\
\hline 3-Nitroaniline & ND & ND & ND & ND \\
\hline 4,6-Dinitro-2-methlyphenol & ND & ND & ND & ND \\
\hline 4-Bromophenyl phenyl ether & ND & ND & ND & $\mathrm{ND}$ \\
\hline 4-Chloro-3-methylphenol & ND & ND & ND & ND \\
\hline 4-Chloroaniline & ND & ND & ND & ND \\
\hline 4-Chlorodiphenyl ether & ND & ND & ND & ND \\
\hline 4-Methylphenol (p-Cresol) & ND & ND & ND & ND \\
\hline 4-Nitroaniline & ND & ND & ND & $\mathrm{ND}$ \\
\hline 4-Nitrophenol & ND & ND & ND & ND \\
\hline Acenaphthene & ND & ND & ND & ND \\
\hline Acenaphthylene & ND & $\mathrm{ND}$ & $\mathrm{ND}$ & ND \\
\hline Anthracene & ND & ND & ND & ND \\
\hline Benzo(a)anthracene & $\mathrm{ND}$ & $\mathrm{ND}$ & ND & $\mathrm{ND}$ \\
\hline Benzo(a)pyrene & ND & $\mathrm{ND}$ & ND & $\mathrm{ND}$ \\
\hline
\end{tabular}

$\mathrm{ND}=$ not detected 
Table 14. NETL-PGH 2001 Groundwater Detection Monitoring Program Results of Analysis - Groundwater Samples Main Plateau - Semivolatile Organic Compounds Constituents ( $\mu \mathrm{g} / \mathrm{L}$ ) (continued)

\begin{tabular}{|c|c|c|c|c|}
\hline \multirow{3}{*}{$\begin{array}{l}\text { Constituent } \\
\text { Sample Date }\end{array}$} & \multicolumn{4}{|c|}{ Well Number and Sample Date } \\
\hline & \multicolumn{2}{|c|}{ MPW-1 } & \multicolumn{2}{|c|}{ MPW-7 } \\
\hline & $05 / 09 / 01$ & $10 / 03 / 01$ & $05 / 07 / 01$ & $10 / 03 / 01$ \\
\hline Benzo(b)fluoranthene & ND & ND & $\mathrm{ND}$ & ND \\
\hline Benzo(ghi)perylene & ND & ND & ND & ND \\
\hline Benzo(k)fluoranthene & ND & ND & ND & ND \\
\hline Bis(2-chloroethoxyl) methane & $\mathrm{ND}$ & $\mathrm{ND}$ & $\mathrm{ND}$ & $\mathrm{ND}$ \\
\hline Bis (2-chloroethyl) ether & ND & ND & ND & ND \\
\hline Bis(2-chloroisopropyl) ether & ND & ND & ND & ND \\
\hline Bis(2-ethylhexyl) phthalate & ND & ND & 110 & ND \\
\hline Butyl benzyl phthalate & ND & ND & ND & ND \\
\hline Carbazole & ND & $\mathrm{ND}$ & $\mathrm{ND}$ & $\mathrm{ND}$ \\
\hline Chrysene & ND & $\mathrm{ND}$ & ND & ND \\
\hline Di-n-butyl phthalate & $\mathrm{ND}$ & $\mathrm{ND}$ & ND & ND \\
\hline Di-n-octly phthalate & ND & ND & ND & ND \\
\hline Dibenzo(a,h)anthracene & ND & $\mathrm{ND}$ & ND & ND \\
\hline Dibenzofuran & ND & $\mathrm{ND}$ & ND & ND \\
\hline Diethyl phthalate & ND & ND & ND & ND \\
\hline Dimethyl phthalate & ND & ND & ND & ND \\
\hline Fluoranthene & ND & ND & ND & $\mathrm{ND}$ \\
\hline Fluorene & ND & ND & ND & ND \\
\hline Hexachlorobenzene & ND & $\mathrm{ND}$ & ND & ND \\
\hline Hexachlorobutadiene & ND & ND & $\mathrm{ND}$ & $\mathrm{ND}$ \\
\hline Hexachlorocyclopentadiene & ND & ND & ND & ND \\
\hline Hexachloroethane & ND & ND & $\mathrm{ND}$ & ND \\
\hline Indeno(1,2,3-cd)pyrene & ND & ND & $\mathrm{ND}$ & $\mathrm{ND}$ \\
\hline Isophorone & ND & ND & $\mathrm{ND}$ & $\mathrm{ND}$ \\
\hline N-Nitroso-Di-n-propylamine & ND & ND & $\mathrm{ND}$ & ND \\
\hline N-nitrosodiphenylamine & ND & ND & $\mathrm{ND}$ & $\mathrm{ND}$ \\
\hline Naphthalene & $\mathrm{ND}$ & ND & ND & $\mathrm{ND}$ \\
\hline Nitrobenzene & ND & ND & $\mathrm{ND}$ & ND \\
\hline Pentachlorophenol & ND & ND & ND & ND \\
\hline Phenanthrene & $\mathrm{ND}$ & $\mathrm{ND}$ & ND & $\mathrm{ND}$ \\
\hline Phenol & ND & ND & ND & ND \\
\hline Pyrene & ND & ND & ND & ND \\
\hline
\end{tabular}

$\mathrm{ND}=$ not detected 
Table 15. NETL-PGH 2001 Groundwater Detection Monitoring Program Results of Analysis - Groundwater Samples Valley Fill - Semivolatile Organic Compounds Constituents ( $\mu \mathrm{g} / \mathrm{L}$ )

\begin{tabular}{|c|c|c|c|c|c|c|}
\hline \multirow{3}{*}{$\begin{array}{l}\text { Constituent } \\
\text { Sample Date }\end{array}$} & \multicolumn{6}{|c|}{ Well Number and Sample Date } \\
\hline & \multicolumn{2}{|c|}{ VFW-2 } & \multirow{2}{*}{$\frac{\text { VFW-2-1 }}{05 / 07 / 01}$} & \multicolumn{2}{|c|}{ VFW-14 } & \multirow{2}{*}{$\frac{\text { VFW-14-1 }}{10 / 04 / 01}$} \\
\hline & $05 / 07 / 01$ & $10 / 04 / 01$ & & $05 / 07 / 01$ & $10 / 04 / 01$ & \\
\hline 1,2,4-Trichlorobenzene & ND & ND & ND & ND & ND & ND \\
\hline 1,2-Dichlorobenzene & $\mathrm{ND}$ & ND & ND & ND & ND & ND \\
\hline 1,3-Dichlorobenzene & ND & ND & ND & ND & ND & ND \\
\hline 1,4-Dichlorobenzene & ND & ND & ND & ND & ND & ND \\
\hline 2,4,5-Trichlorophenol & ND & ND & ND & ND & ND & ND \\
\hline 2,4,6-Trichlorophenol & $\mathrm{ND}$ & ND & ND & ND & ND & ND \\
\hline 2,4-Dichlorophenol & ND & ND & ND & ND & ND & ND \\
\hline 2,4-Dimethylphenol & ND & ND & ND & ND & ND & ND \\
\hline 2,4-Dinitrophenol & $\mathrm{ND}$ & ND & ND & ND & ND & ND \\
\hline 2,4-Dinitrotoulene & $\mathrm{ND}$ & ND & ND & $\mathrm{ND}$ & ND & ND \\
\hline 2,6-Dinitrotoluene & $\mathrm{ND}$ & ND & ND & ND & ND & ND \\
\hline 2-Chloronaphthalene & $\mathrm{ND}$ & ND & ND & ND & ND & ND \\
\hline 2-Chlorophenol & $\mathrm{ND}$ & ND & ND & ND & ND & ND \\
\hline 2-Methylnaphthalene & $\mathrm{ND}$ & ND & ND & ND & ND & ND \\
\hline 2-Methylphenol (o-Cresol) & $\mathrm{ND}$ & ND & ND & $\mathrm{ND}$ & ND & ND \\
\hline 2-Nitroaniline & $\mathrm{ND}$ & ND & ND & ND & ND & ND \\
\hline 2-Nitrophenol & $\mathrm{ND}$ & ND & ND & $\mathrm{ND}$ & ND & ND \\
\hline 3,3'-Dichlorobenzidine & ND & ND & ND & ND & ND & ND \\
\hline 3-Nitroaniline & $\mathrm{ND}$ & ND & ND & ND & ND & ND \\
\hline 4,6-Dinitro-2-methlyphenol & $\mathrm{ND}$ & ND & ND & $\mathrm{ND}$ & ND & ND \\
\hline 4-Bromophenyl phenyl ether & $\mathrm{ND}$ & ND & ND & ND & ND & ND \\
\hline 4-Chloro-3-methylphenol & $\mathrm{ND}$ & ND & ND & ND & ND & ND \\
\hline 4-Chloroaniline & $\mathrm{ND}$ & ND & ND & $\mathrm{ND}$ & ND & ND \\
\hline 4-Chlorodiphenyl ether & $\mathrm{ND}$ & ND & ND & $\mathrm{ND}$ & ND & ND \\
\hline 4-Methylphenol (p-Cresol) & $\mathrm{ND}$ & ND & ND & ND & ND & ND \\
\hline 4-Nitroaniline & ND & $\mathrm{ND}$ & ND & ND & ND & ND \\
\hline 4-Nitrophenol & $\mathrm{ND}$ & ND & ND & ND & ND & ND \\
\hline Acenaphthene & $\mathrm{ND}$ & ND & ND & ND & ND & ND \\
\hline Acenaphthylene & $\mathrm{ND}$ & $\mathrm{ND}$ & ND & $\mathrm{ND}$ & ND & ND \\
\hline Anthracene & ND & ND & ND & ND & ND & ND \\
\hline Benzo(a)anthracene & $\mathrm{ND}$ & ND & ND & ND & ND & ND \\
\hline Benzo(a)pyrene & $\mathrm{ND}$ & $\mathrm{ND}$ & ND & ND & $\mathrm{ND}$ & ND \\
\hline
\end{tabular}

$\mathrm{ND}=$ not detected 
Table 15. NETL-PGH 2001 Groundwater Detection Monitoring Program Results of Analysis - Groundwater Samples Valley Fill - Semivolatile Organic Compounds Constituents ( $\mu \mathrm{g} / \mathrm{L}$ )

(continued)

\begin{tabular}{|c|c|c|c|c|c|c|}
\hline \multirow{3}{*}{$\begin{array}{l}\text { Constituent } \\
\text { Sample Date }\end{array}$} & \multicolumn{6}{|c|}{ Well Number and Sample Date } \\
\hline & \multicolumn{2}{|c|}{ VFW-2 } & \multirow{2}{*}{$\begin{array}{l}\text { VFW-2-1 } \\
05 / 07 / 01 \\
\end{array}$} & \multicolumn{2}{|c|}{ VFW-14 } & \multirow{2}{*}{$\begin{array}{c}\text { VFW-14- } \\
10 / 04 / 01 \\
\end{array}$} \\
\hline & 05/07/01 & $10 / 04 / 01$ & & 05/07/01 & 10/04/01 & \\
\hline Benzo(b)fluoranthene & ND & ND & ND & ND & $\mathrm{ND}$ & ND \\
\hline Benzo(ghi)perylene & ND & ND & ND & ND & ND & ND \\
\hline Benzo(k)fluoranthene & ND & ND & ND & ND & ND & ND \\
\hline Bis(2-chloroethoxyl) methane & ND & ND & ND & ND & ND & ND \\
\hline Bis (2-chloroethyl) ether & ND & ND & ND & ND & ND & ND \\
\hline Bis(2-chloroisopropyl) ether & ND & ND & ND & ND & $\mathrm{ND}$ & ND \\
\hline Bis(2-ethylhexyl) phthalate & ND & $\mathrm{ND}$ & $\mathrm{ND}$ & ND & $\mathrm{ND}$ & $\mathrm{ND}$ \\
\hline Butyl benzyl phthalate & ND & ND & ND & ND & ND & ND \\
\hline Carbazole & ND & ND & ND & ND & ND & ND \\
\hline Chrysene & ND & ND & ND & $\mathrm{ND}$ & ND & ND \\
\hline Di-n-butyl phthalate & ND & ND & ND & ND & ND & ND \\
\hline Di-n-octly phthalate & ND & $\mathrm{ND}$ & $\mathrm{ND}$ & ND & ND & $\mathrm{ND}$ \\
\hline Dibenzo(a,h)anthracene & ND & ND & ND & ND & ND & ND \\
\hline Dibenzofuran & ND & ND & ND & ND & ND & ND \\
\hline Diethyl phthalate & $\mathrm{ND}$ & ND & $\mathrm{ND}$ & ND & $\mathrm{ND}$ & ND \\
\hline Dimethyl phthalate & ND & ND & ND & ND & ND & ND \\
\hline Fluoranthene & ND & ND & ND & ND & ND & ND \\
\hline Fluorene & ND & ND & ND & ND & ND & ND \\
\hline Hexachlorobenzene & ND & ND & ND & ND & ND & ND \\
\hline Hexachlorobutadiene & ND & ND & ND & ND & ND & ND \\
\hline Hexachlorocyclopentadiene & $\mathrm{ND}$ & $\mathrm{ND}$ & $\mathrm{ND}$ & ND & $\mathrm{ND}$ & $\mathrm{ND}$ \\
\hline Hexachloroethane & ND & ND & ND & ND & ND & ND \\
\hline Indeno(1,2,3-cd)pyrene & $\mathrm{ND}$ & $\mathrm{ND}$ & $\mathrm{ND}$ & ND & $\mathrm{ND}$ & $\mathrm{ND}$ \\
\hline Isophorone & $\mathrm{ND}$ & ND & ND & ND & ND & $\mathrm{ND}$ \\
\hline N-Nitroso-Di-n-propylamine & ND & ND & ND & ND & ND & ND \\
\hline N-nitrosodiphenylamine & ND & ND & ND & $\mathrm{ND}$ & $\mathrm{ND}$ & ND \\
\hline Naphthalene & ND & ND & ND & ND & ND & ND \\
\hline Nitrobenzene & ND & ND & ND & ND & ND & ND \\
\hline Pentachlorophenol & ND & $\mathrm{ND}$ & ND & ND & ND & $\mathrm{ND}$ \\
\hline Phenanthrene & ND & ND & ND & ND & ND & ND \\
\hline Phenol & ND & $\mathrm{ND}$ & $\mathrm{ND}$ & $\mathrm{ND}$ & ND & $\mathrm{ND}$ \\
\hline Pyrene & ND & ND & ND & ND & ND & $\mathrm{ND}$ \\
\hline
\end{tabular}

$\mathrm{ND}=$ not detected 
Table 16. NETL-PGH 2001 Groundwater Detection Monitoring Program

Results of Analysis - Groundwater Samples

Valley Fill - TPH Constituents (mg/L)

\begin{tabular}{|c|c|c|c|c|c|c|c|c|c|}
\hline \multirow{3}{*}{$\begin{array}{l}\text { Constituent } \\
\text { Date }\end{array}$} & \multicolumn{9}{|c|}{ Well Number and Sample Date } \\
\hline & \multicolumn{2}{|c|}{ VFW-2 } & \multirow{2}{*}{\begin{tabular}{|l|} 
VFW-2-1 \\
$05 / 07 / 01$
\end{tabular}} & \multicolumn{2}{|c|}{ VFW-4 } & \multicolumn{2}{|c|}{ VFW-7 } & \multicolumn{2}{|c|}{ VFW-9 } \\
\hline & $05 / 07 / 01$ & $10 / 04 / 01$ & & $05 / 07 / 01$ & $10 / 03 / 01$ & $05 / 08 / 01$ & $10 / 04 / 01$ & $05 / 08 / 01$ & $10 / 04 / 01$ \\
\hline TPH-DRO & ND & ND & ND & ND & ND & ND & ND & ND & ND \\
\hline \multirow{3}{*}{$\begin{array}{l}\text { Constituent } \\
\text { Sate }\end{array}$} & \multicolumn{9}{|c|}{ Well Number and Sample Date } \\
\hline & \multicolumn{2}{|c|}{ VFW-10 } & \multicolumn{2}{|c|}{ VFW-11 } & \multicolumn{2}{|c|}{ VFW-12 } & VFW-12-1 & \multicolumn{2}{|c|}{ VFW-14 } \\
\hline & 05/09/01 & $10 / 04 / 01$ & 05/08/01 & $10 / 04 / 01$ & $05 / 08 / 01$ & $10 / 04 / 01$ & $10 / 04 / 01$ & $5 / 07 / 01$ & $10 / 04 / 01$ \\
\hline TPH-DRO & ND & ND & ND & ND & ND & ND & ND & ND & ND \\
\hline
\end{tabular}

$\mathrm{ND}=$ not detected; NS = not sampled; TPH = total petroleum hydrocarbons; TPH-DRO = total petroleum hydrocarbons -diesel range organics . 
Table 17. NETL-PGH 2001 Groundwater Detection Monitoring Program Results of Analysis - Groundwater Samples, Main Plateau - Volatile Organic Compounds Constituents ( $\mu \mathrm{g} / \mathrm{L}$ )

\begin{tabular}{|c|c|c|c|c|c|c|c|c|c|c|c|}
\hline \multirow{3}{*}{ Constituent } & \multicolumn{11}{|c|}{ Well Number and Sample Date } \\
\hline & \multicolumn{2}{|c|}{ MPW-1 } & \multicolumn{2}{|c|}{ MPW-7 } & \multicolumn{2}{|c|}{ MPW-7D } & \multicolumn{2}{|c|}{ MPW-8 } & \multirow{2}{*}{$\begin{array}{c}\text { MPW-8-1 } \\
10 / 03 / 01 \\
\end{array}$} & \multicolumn{2}{|c|}{ MPW-9 } \\
\hline & $05 / 09 / 01$ & $10 / 03 / 01$ & $05 / 07 / 01$ & $10 / 03 / 01$ & 05/07/01 & $10 / 02 / 01$ & $05 / 09 / 01$ & $10 / 03 / 01$ & & 05/07/01 & $10 / 03 / 01$ \\
\hline 1,1,1-Trichloroethane & $\mathrm{ND}$ & ND & ND & $\mathrm{ND}$ & $\mathrm{ND}$ & NS & $\mathrm{ND}$ & $\mathrm{ND}$ & $\mathrm{ND}$ & ND & ND \\
\hline 1,1,2,2-Tetrachloroethane & ND & ND & ND & ND & ND & NS & ND & ND & ND & ND & ND \\
\hline 1,1,2-Trichloroethane & ND & ND & ND & ND & ND & NS & ND & ND & ND & ND & ND \\
\hline 1,1-Dichloroethane & ND & ND & ND & ND & ND & NS & ND & 8.0 & 8.6 & ND & ND \\
\hline 1,1-Dichloroethene & ND & ND & ND & ND & ND & NS & ND & ND & ND & ND & ND \\
\hline 1,2-Dichloroethane & ND & ND & ND & ND & ND & NS & ND & ND & ND & ND & ND \\
\hline 1,2-Dichloropropane & ND & ND & ND & ND & ND & NS & ND & ND & ND & ND & ND \\
\hline 2-Butanone (MEK) & ND & ND & ND & ND & ND & NS & ND & ND & ND & ND & ND \\
\hline 2-Hexanone & ND & $\mathrm{ND}$ & $\mathrm{ND}$ & ND & ND & NS & ND & $\mathrm{ND}$ & $\mathrm{ND}$ & ND & ND \\
\hline 4-Methyl-2-pentanone (MIBK) & ND & ND & ND & ND & ND & NS & ND & ND & ND & ND & ND \\
\hline Acetone & ND & ND & ND & ND & ND & NS & ND & ND & ND & ND & ND \\
\hline Benzene & ND & ND & ND & ND & ND & NS & ND & ND & ND & ND & ND \\
\hline Bromodichloromethane & ND & ND & ND & ND & ND & NS & ND & ND & ND & ND & ND \\
\hline Bromoform & ND & ND & ND & ND & ND & NS & ND & ND & ND & ND & ND \\
\hline Bromomethane & ND & ND & ND & ND & ND & NS & ND & ND & ND & ND & ND \\
\hline Carbon Disulfide & ND & ND & $\mathrm{ND}$ & ND & $\mathrm{ND}$ & NS & ND & ND & ND & ND & ND \\
\hline Carbon Tetrachloride & ND & ND & ND & ND & ND & NS & $\mathrm{ND}$ & ND & ND & ND & ND \\
\hline Chlorobenzene & ND & ND & ND & ND & ND & NS & ND & ND & ND & ND & ND \\
\hline Chloroethane & ND & ND & ND & ND & ND & NS & ND & ND & ND & ND & ND \\
\hline Chloroform & ND & ND & ND & ND & ND & NS & ND & ND & ND & ND & ND \\
\hline Chloromethane & ND & ND & ND & ND & ND & NS & ND & ND & ND & ND & ND \\
\hline cis-1,2-Dichloroethene & ND & ND & ND & ND & ND & NS & ND & ND & ND & ND & ND \\
\hline cis-1,3-Dichloropropene & ND & ND & ND & ND & ND & NS & ND & ND & ND & ND & ND \\
\hline Dibromochloromethane & $\mathrm{ND}$ & ND & $\mathrm{ND}$ & $\mathrm{ND}$ & ND & NS & ND & ND & $\mathrm{ND}$ & $\mathrm{ND}$ & $\mathrm{ND}$ \\
\hline Ethylbenzene & $\mathrm{ND}$ & $\mathrm{ND}$ & $\mathrm{ND}$ & ND & ND & NS & ND & ND & $\mathrm{ND}$ & ND & ND \\
\hline Methylene chloride & ND & ND & ND & ND & ND & NS & ND & ND & ND & ND & ND \\
\hline Styrene & ND & ND & ND & ND & ND & NS & ND & ND & ND & ND & ND \\
\hline Tetrachloroethene & ND & ND & ND & ND & ND & NS & 7.5 & ND & ND & ND & ND \\
\hline Toulene & ND & ND & ND & ND & ND & NS & ND & ND & ND & ND & ND \\
\hline Total Xylenes & ND & ND & ND & ND & ND & NS & ND & ND & ND & ND & ND \\
\hline trans-1,2-Dichloroethene & ND & ND & ND & ND & ND & NS & ND & ND & ND & ND & ND \\
\hline trans-1,3-Dichloropropene & ND & ND & ND & ND & ND & NS & ND & ND & ND & ND & ND \\
\hline Trichloroethene & ND & ND & ND & ND & ND & NS & $\mathrm{ND}$ & $\mathrm{ND}$ & ND & ND & ND \\
\hline Vinyl chloride & ND & ND & ND & ND & ND & NS & ND & ND & ND & ND & ND \\
\hline
\end{tabular}


Table 17. NETL-PGH 2001 Groundwater Detection Monitoring Program

Results of Analysis - Groundwater Samples, Main Plateau - Volatile Organic Compounds Constituents ( $\mu \mathrm{g} / \mathrm{L}$ )

(continued)

\begin{tabular}{|c|c|c|c|c|c|c|}
\hline \multirow{3}{*}{\begin{tabular}{|l|} 
Constituent \\
\\
\\
Sample Date:
\end{tabular}} & \multicolumn{6}{|c|}{ Well Number and Sample Date } \\
\hline & \multicolumn{2}{|c|}{ MPW-10 } & \multicolumn{2}{|c|}{ MPW-11 } & \multicolumn{2}{|c|}{ MPW-12 } \\
\hline & $05 / 07 / 01$ & $10 / 03 / 01$ & $05 / 08 / 01$ & $10 / 03 / 01$ & $05 / 08 / 01$ & $10 / 02 / 01$ \\
\hline 1,1,1-Trichloroethane & ND & ND & $\mathrm{ND}$ & $\mathrm{ND}$ & $\mathrm{ND}$ & NS \\
\hline 1,1,2,2-Tetrachloroethane & $\mathrm{ND}$ & $\mathrm{ND}$ & ND & ND & $\mathrm{ND}$ & NS \\
\hline 1,1,2-Trichloroethane & ND & ND & ND & ND & ND & NS \\
\hline 1,1-Dichloroethane & $\mathrm{ND}$ & $\mathrm{ND}$ & $\mathrm{ND}$ & ND & $\mathrm{ND}$ & NS \\
\hline 1,1-Dichloroethene & ND & ND & ND & ND & ND & NS \\
\hline 1,2-Dichloroethane & $\mathrm{ND}$ & $\mathrm{ND}$ & ND & ND & ND & NS \\
\hline 1,2-Dichloropropane & ND & ND & ND & ND & ND & NS \\
\hline 2-Butanone (MEK) & ND & ND & ND & ND & ND & NS \\
\hline 2-Hexanone & ND & $\mathrm{ND}$ & $\mathrm{ND}$ & $\mathrm{ND}$ & $\mathrm{ND}$ & NS \\
\hline 4-Methyl-2-pentanone (MIBK) & $\mathrm{ND}$ & $\mathrm{ND}$ & ND & $\mathrm{ND}$ & $\mathrm{ND}$ & NS \\
\hline Acetone & ND & ND & ND & ND & ND & NS \\
\hline Benzene & ND & ND & ND & ND & ND & NS \\
\hline Bromodichloromethane & ND & ND & ND & ND & ND & NS \\
\hline Bromoform & ND & ND & ND & ND & ND & NS \\
\hline Bromomethane & ND & ND & ND & ND & ND & NS \\
\hline Carbon Disulfide & ND & ND & ND & $\mathrm{ND}$ & $\mathrm{ND}$ & NS \\
\hline Carbon Tetrachloride & ND & ND & ND & ND & $\mathrm{ND}$ & NS \\
\hline Chlorobenzene & ND & ND & ND & ND & ND & NS \\
\hline Chloroethane & $\mathrm{ND}$ & $\mathrm{ND}$ & $\mathrm{ND}$ & ND & $\mathrm{ND}$ & NS \\
\hline Chloroform & $\mathrm{ND}$ & ND & ND & $\mathrm{ND}$ & $\mathrm{ND}$ & NS \\
\hline Chloromethane & $\mathrm{ND}$ & $\mathrm{ND}$ & ND & $\mathrm{ND}$ & $\mathrm{ND}$ & NS \\
\hline cis-1,2-Dchloroethene & ND & $\mathrm{ND}$ & ND & $\mathrm{ND}$ & $\mathrm{ND}$ & NS \\
\hline cis-1,3-Dichloropropene & ND & ND & ND & ND & $\mathrm{ND}$ & NS \\
\hline Dibromochloromethane & ND & ND & ND & ND & ND & NS \\
\hline Ethylbenzene & $\mathrm{ND}$ & $\mathrm{ND}$ & $\mathrm{ND}$ & ND & $\mathrm{ND}$ & NS \\
\hline Methylene chloride & $\mathrm{ND}$ & ND & ND & ND & $\mathrm{ND}$ & NS \\
\hline Styrene & $\mathrm{ND}$ & ND & ND & $\mathrm{ND}$ & ND & NS \\
\hline Tetrachloroethene & ND & $\mathrm{ND}$ & ND & $\mathrm{ND}$ & $\mathrm{ND}$ & NS \\
\hline Toulene & $\mathrm{ND}$ & ND & ND & ND & ND & NS \\
\hline Total Xylenes & ND & ND & ND & ND & ND & NS \\
\hline
\end{tabular}




\begin{tabular}{|l|c|c|c|c|c|c|} 
trans-1,2-Dichloroethene & ND & ND & ND & ND & ND & NS \\
\hline trans-1,3-Dichloropropene & ND & ND & ND & ND & ND & NS \\
\hline Trichloroethene & ND & ND & ND & ND & ND & NS \\
\hline Vinyl chloride & ND & ND & ND & ND & ND & NS \\
\hline
\end{tabular}

$\mathrm{ND}=$ not detected; NS = not sampled; MEK = methyl ethyl ketone; MIBK = methyl isobutyl ketone. 
Table 18. NETL-PGH 2001 Groundwater Detection Monitoring Program Results of Analysis - Groundwater Samples, Valley Fill - Volatile Organic Compounds Constituents $(\mu \mathrm{g} / \mathrm{L})$

\begin{tabular}{|c|c|c|c|c|c|c|c|c|c|}
\hline \multirow{3}{*}{ Constituent } & \multicolumn{9}{|c|}{ Well Number and Sample Date } \\
\hline & \multicolumn{2}{|c|}{ VFW-2 } & \multicolumn{2}{|c|}{ VFW-3 } & \multirow{2}{*}{$\begin{array}{c}\text { VFW-3- } \\
1 \\
05 / 09 / 01 \\
\end{array}$} & \multicolumn{2}{|c|}{ VFW-10 } & \multicolumn{2}{|c|}{ VFW-14 } \\
\hline & 05/07/01 & $10 / 04 / 01$ & 05/09/01 & $10 / 03 / 01$ & & 05/09/01 & $10 / 04 / 01$ & 05/07/01 & 10/03/01 \\
\hline 1,1,1-Trichloroethane & ND & ND & ND & ND & ND & ND & ND & ND & ND \\
\hline 1,1,2,2-Tetrachloroethane & ND & ND & ND & ND & ND & ND & ND & ND & ND \\
\hline 1,1,2-Trichloroethane & ND & ND & ND & ND & ND & $\mathrm{ND}$ & ND & ND & ND \\
\hline 1,1-Dichloroethane & ND & ND & ND & ND & ND & ND & ND & ND & $\mathrm{ND}$ \\
\hline 1,1-Dichloroethene & ND & ND & ND & ND & ND & ND & ND & ND & ND \\
\hline 1,2-Dichloroethane & ND & ND & ND & ND & ND & ND & ND & ND & ND \\
\hline 1,2-Dichloropropane & ND & ND & ND & ND & ND & ND & ND & ND & ND \\
\hline 2-Butanone (MEK) & ND & ND & ND & ND & ND & ND & ND & ND & ND \\
\hline 2-Hexanone & ND & ND & ND & ND & ND & ND & ND & ND & ND \\
\hline $\begin{array}{l}4-\text { M e t h y } 1-2-p \text { e } n t \text { a n o n e } \\
\text { MIBK) }\end{array}$ & ND & ND & ND & ND & ND & ND & ND & ND & ND \\
\hline Acetone & ND & ND & ND & ND & ND & $\mathrm{ND}$ & ND & ND & ND \\
\hline Benzene & ND & ND & ND & ND & ND & ND & ND & ND & ND \\
\hline Bromodichloromethane & ND & ND & ND & ND & ND & ND & ND & ND & ND \\
\hline Bromoform & ND & ND & ND & ND & ND & ND & ND & ND & ND \\
\hline Bromomethane & ND & ND & ND & ND & $\mathrm{ND}$ & ND & ND & ND & ND \\
\hline Carbon Disulfide & ND & ND & ND & ND & ND & ND & ND & ND & ND \\
\hline Carbon Tetrachloride & $\mathrm{ND}$ & ND & ND & ND & ND & ND & ND & ND & ND \\
\hline Chlorobenzene & ND & ND & ND & ND & ND & ND & ND & ND & ND \\
\hline Chloroethane & ND & ND & ND & ND & $\mathrm{ND}$ & ND & ND & ND & ND \\
\hline Chloroform & ND & $\mathrm{ND}$ & ND & ND & ND & ND & ND & ND & ND \\
\hline Chloromethane & ND & ND & ND & ND & ND & ND & ND & ND & ND \\
\hline cis-1,2-Dichloroethene & ND & ND & ND & ND & ND & ND & ND & ND & ND \\
\hline cis-1,3-Dichloropropene & ND & ND & $\mathrm{ND}$ & ND & ND & ND & ND & ND & ND \\
\hline Dibromochloromethane & ND & ND & ND & ND & ND & ND & ND & ND & ND \\
\hline Ethylbenzene & ND & ND & ND & ND & ND & ND & ND & ND & ND \\
\hline Methylene chloride & ND & ND & ND & ND & ND & ND & ND & ND & ND \\
\hline Styrene & ND & ND & ND & ND & ND & ND & ND & ND & ND \\
\hline Tetrachloroethene & $\mathrm{ND}$ & ND & 15 & 17 & 6.8 & ND & ND & ND & ND \\
\hline Toulene & ND & ND & ND & ND & ND & ND & ND & ND & ND \\
\hline Total Xylenes & ND & ND & ND & ND & ND & ND & ND & ND & ND \\
\hline trans-1,2-Dichloroethene & ND & ND & ND & 7.9 & ND & ND & ND & ND & ND \\
\hline trans-1,3-Dichloropropene & $\mathrm{ND}$ & ND & ND & ND & ND & $\mathrm{ND}$ & ND & ND & ND \\
\hline Trichloroethene & ND & ND & ND & ND & ND & ND & ND & ND & ND \\
\hline
\end{tabular}




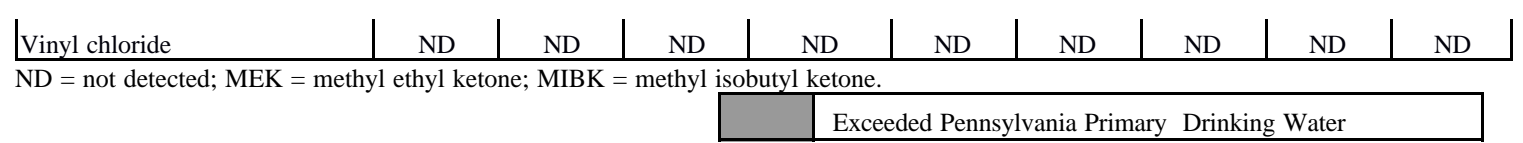




\section{Table 19. NETL-MGN March 2001 Groundwater Data}

for "Morgantown Aquifer"

\begin{tabular}{|c|c|c|c|c|}
\hline \multirow[b]{2}{*}{ Parameter } & \multicolumn{4}{|c|}{ Sample Location } \\
\hline & D1-M & D2-M & D3-M & D4-M \\
\hline $\mathrm{pH}(\mathrm{s} . \mathrm{u})$ & 7.0 & 9.0 & 8.0 & 7.0 \\
\hline Specific Conductance ( $\mu \mathrm{mhos}$ ) & 260 & 582 & 307 & 1060 \\
\hline Temperature $\left({ }^{\circ} \mathrm{C}\right)$ & 14.0 & 14.0 & 13.0 & 14.0 \\
\hline Arsenic (total, mg/L) & ND & ND & ND & ND \\
\hline Barium (total, mg/L) & ND & ND & 1.0 & 1.0 \\
\hline Cadmium (total, mg/L) & ND & ND & ND & ND \\
\hline Chromium (total, mg/L) & ND & ND & ND & ND \\
\hline Lead (total, mg/L) & ND & ND & ND & ND \\
\hline Mercury (total, mg/L) & ND & ND & ND & ND \\
\hline Selenium (total, mg/L) & ND & ND & ND & ND \\
\hline Silver (total, mg/L) & ND & ND & ND & ND \\
\hline Iron (total, mg/L) & 16 & 1.0 & ND & ND \\
\hline Manganese (total, mg/L) & 1.0 & ND & ND & 1.0 \\
\hline Sodium (total, mg/L) & 7.0 & 130 & 38 & 22 \\
\hline Vanadium (total, mg/L) & ND & ND & ND & ND \\
\hline Benzene (mg/L) & ND & ND & ND & ND \\
\hline Toluene (mg/L) & ND & ND & ND & ND \\
\hline Ethylbenzene (mg/L) & ND & ND & ND & ND \\
\hline Total Xylenes (mg/L) & ND & ND & ND & ND \\
\hline Total Organic Halides (mg/L) & ND & ND & ND & ND \\
\hline Chloride (mg/L) & 18 & ND & ND & 48 \\
\hline Sulfate $(\mathrm{mg} / \mathrm{L})$ & 31 & 4.0 & 17 & 10 \\
\hline Nitrate Nitrogen (mg/L) & ND & ND & ND & ND \\
\hline Fluoride (mg/L) & 0.07 & 0.39 & 0.13 & 0.11 \\
\hline Total Recoverable Phenolics (mg/L) & ND & ND & ND & ND \\
\hline Cyanide (total, mg/L) & ND & ND & ND & ND \\
\hline Total Organic Carbon (mg/L) & 2.0 & 2.0 & 0.75 & 1.0 \\
\hline Naphthalene $(\mu \mathrm{g} / \mathrm{L})$ & ND & ND & ND & ND \\
\hline Other Semivolatiles & ND & ND & ND & ND \\
\hline
\end{tabular}

$\mathrm{ND}=$ not detected; s.u. = standard units. 
Table 20. NETL-MGN March 2001 Groundwater Data for "A Aquifer"

\begin{tabular}{|c|c|c|c|c|c|c|c|c|c|c|c|c|c|}
\hline \multirow[b]{2}{*}{ Parameter } & \multicolumn{13}{|c|}{ Sample Location } \\
\hline & A & B & SP1-A & SP4-A & SP8-A & SP9-A & I & $\mathbf{J}$ & $\mathbf{K}$ & $\mathbf{L}$ & M & $\mathbf{N}$ & GAS-4 \\
\hline $\mathrm{pH}(\mathrm{s} . \mathrm{u})$ & 6.0 & 6.0 & 6.0 & 7.0 & 6.0 & 6.0 & 6.0 & 6.0 & 5.0 & 5.0 & 5.0 & 5.0 & 7.0 \\
\hline Specific Conductance ( $\mu$ mhos) & 275 & 206 & 270 & 239 & 236 & 290 & 1070 & 1118 & 1210 & 1492 & 1025 & 1180 & 1285 \\
\hline Temperature $\left({ }^{\circ} \mathrm{C}\right)$ & 14 & 14 & 14 & 14 & 15 & 14 & 16 & 16 & 14 & 15 & 13 & 15 & 14 \\
\hline Arsenic (total, mg/L) & ND & ND & ND & ND & ND & ND & ND & ND & ND & ND & ND & ND & ND \\
\hline Barium (total, mg/L) & ND & ND & ND & ND & ND & ND & 1 & ND & ND & ND & ND & ND & ND \\
\hline Cadmium (total, mg/L) & ND & ND & ND & ND & ND & ND & ND & ND & ND & 0.008 & ND & ND & ND \\
\hline Chromium (total, mg/L) & ND & ND & ND & ND & ND & ND & ND & ND & ND & ND & ND & ND & ND \\
\hline Lead (total, mg/L) & ND & ND & ND & ND & ND & ND & ND & ND & ND & ND & ND & ND & ND \\
\hline Mercury (total, mg/L) & ND & ND & ND & ND & ND & ND & ND & ND & ND & ND & ND & ND & ND \\
\hline Selenium (total, mg/L) & ND & ND & ND & ND & ND & ND & ND & ND & ND & ND & ND & ND & ND \\
\hline Silver (total, mg/L) & ND & ND & ND & ND & ND & ND & ND & ND & ND & ND & ND & ND & ND \\
\hline Iron (total, mg/L) & 21 & 33 & 41 & 1 & 39 & ND & 28 & 1 & ND & 1 & 4 & ND & 15 \\
\hline Manganese (total, mg/L) & 1.0 & 1.0 & 2 & ND & 3 & 2 & ND & ND & 2 & 1 & 2 & ND & 1.0 \\
\hline Sodium (total, mg/L) & 6 & 5 & 14 & 7 & 7 & 170 & 16 & 60 & 110 & 280 & 22 & 57 & 20 \\
\hline Vanadium (total, mg/L) & ND & ND & ND & ND & ND & ND & ND & ND & ND & ND & ND & $\mathrm{ND}$ & ND \\
\hline Benzene (mg/L) & ND & ND & ND & ND & ND & ND & ND & ND & ND & ND & ND & ND & ND \\
\hline Toluene (mg/L) & ND & ND & ND & ND & ND & ND & ND & ND & ND & ND & ND & ND & ND \\
\hline Ethylbenzene (mg/L) & ND & ND & ND & ND & ND & ND & ND & ND & ND & ND & ND & ND & ND \\
\hline Total Xylenes (mg/L) & ND & ND & ND & ND & ND & ND & ND & ND & ND & ND & ND & ND & ND \\
\hline Total Organic Halides (mg/L) & ND & ND & ND & ND & ND & ND & ND & ND & ND & ND & ND & ND & ND \\
\hline Chloride (mg/L) & ND & 6.0 & ND & 31 & 44 & 410 & 28 & 190 & 280 & 710 & 33 & 180 & 230 \\
\hline Sulfate (mg/L) & 14 & 20 & 52 & 24 & 10 & 68 & 25 & 53 & 81 & 110 & 100 & 60 & 74 \\
\hline Nitrate Nitrogen $(\mathrm{mg} / \mathrm{L})$ & ND & ND & ND & ND & ND & 1 & ND & 1 & 2 & 2 & ND & 1 & ND \\
\hline Fluoride (mg/L) & 0.05 & ND & ND & 0.09 & ND & ND & 0.06 & 0.06 & 0.34 & 0.33 & 0.13 & 0.16 & 0.13 \\
\hline Total Recoverable Phenolics (mg/L) & ND & ND & ND & ND & ND & ND & ND & ND & ND & ND & ND & ND & ND \\
\hline Cyanide (total, $\mathrm{mg} / \mathrm{L}$ ) & ND & ND & ND & ND & ND & ND & ND & ND & ND & ND & $\mathrm{ND}$ & ND & ND \\
\hline Total Organic Carbon (mg/L) & 1.75 & 0.75 & 2.25 & 0.75 & 1.75 & 1.0 & 4.25 & ND & 1.75 & 2.25 & 2.25 & 1.5 & 7.5 \\
\hline Naphthalene $(\mu \mathrm{g} / \mathrm{L})$ & ND & ND & ND & ND & ND & ND & ND & ND & ND & ND & ND & ND & ND \\
\hline Other Semivolatiles & ND & ND & ND & ND & ND & ND & ND & ND & ND & ND & ND & ND & ND \\
\hline
\end{tabular}

$\mathrm{ND}=$ not detected; s.u. = standard units . 
Table 21. NETL-MGN March 2001 Groundwater Data for "B-C Aquifer"

\begin{tabular}{|c|c|c|c|c|c|}
\hline \multirow[b]{2}{*}{ Parameter } & \multicolumn{5}{|c|}{ Sample Location } \\
\hline & 11 & SP2-BC & $32 \mathrm{~A}$ & 31 & GAS-5 \\
\hline $\mathrm{pH}(\mathrm{s} . \mathrm{u})$ & 6.0 & 7.0 & 5.0 & 5.0 & 7.0 \\
\hline Specific Conductance ( $\mu$ mhos) & 280 & 300 & 1317 & 1185 & 1300 \\
\hline Temperature $\left({ }^{\circ} \mathrm{C}\right)$ & 14 & 13 & 13 & 16 & 13 \\
\hline Arsenic (total, mg/L) & ND & ND & ND & ND & ND \\
\hline Barium (total, mg/L) & ND & ND & ND & ND & ND \\
\hline Cadmium (total, mg/L) & ND & ND & ND & ND & ND \\
\hline Chromium (total, mg/L) & ND & ND & ND & ND & ND \\
\hline Lead (total, mg/L) & ND & ND & ND & ND & ND \\
\hline Mercury (total, mg/L) & ND & ND & ND & ND & ND \\
\hline Selenium (total, mg/L) & ND & ND & ND & ND & ND \\
\hline Silver (total, mg/L) & ND & ND & ND & ND & ND \\
\hline Iron (total, mg/L) & 36 & ND & ND & ND & 1 \\
\hline Manganese (total, mg/L) & 1 & ND & 3 & 4 & ND \\
\hline Sodium (total, mg/L) & 5 & 4 & 190 & 79 & 37 \\
\hline Vanadium (total, mg/L) & ND & ND & ND & ND & ND \\
\hline Benzene (mg/L) & ND & ND & ND & ND & ND \\
\hline Toluene (mg/L) & ND & ND & ND & ND & ND \\
\hline Ethylbenzene (mg/L) & ND & ND & ND & ND & ND \\
\hline Total Xylenes (mg/L) & ND & ND & ND & ND & ND \\
\hline Total Organic Halides (mg/L) & ND & ND & ND & ND & ND \\
\hline Chloride (mg/L) & ND & 8 & 460 & 150 & 92 \\
\hline Sulfate $(\mathrm{mg} / \mathrm{L})$ & 20 & 21 & 110 & 58 & 100 \\
\hline Nitrate Nitrogen (mg/L) & ND & 1 & 1 & ND & ND \\
\hline Fluoride (mg/L) & ND & 0.09 & ND & 0.11 & 0.09 \\
\hline Total Recoverable Phenolics (mg/L) & ND & ND & ND & ND & ND \\
\hline Cyanide (total, mg/L) & ND & ND & ND & ND & ND \\
\hline Total Organic Carbon (mg/L) & 1.25 & 1.75 & 2.25 & 2.0 & 4.75 \\
\hline Naphthalene (ug/L) & ND & ND & ND & ND & ND \\
\hline Other Semivolatiles & ND & ND & ND & ND & ND \\
\hline
\end{tabular}

ND = not detected; s.u. = standard units. 
Table 22. NETL-MGN August 2001 Groundwater Data for "Morgantown Aquifer"

\begin{tabular}{|c|c|c|c|c|}
\hline \multirow[b]{2}{*}{ Parameter } & \multicolumn{4}{|c|}{ Sample Location } \\
\hline & D1M & D2M & D3M & D4M \\
\hline $\mathrm{pH}(\mathrm{s} . \mathrm{u})$ & 6.6 & 9.0 & 7.7 & 7.1 \\
\hline Specific Conductance ( $\mu$ mhos) & 380 & 460 & 470 & 394 \\
\hline Temperature $\left({ }^{\circ} \mathrm{C}\right)$ & 16.6 & 16.4 & 15.4 & 15.9 \\
\hline Arsenic (total, $\mathrm{mg} / \mathrm{L}$ ) & 0.009 & ND & ND & ND \\
\hline Barium (total, mg/L) & 0.22 & 0.16 & 0.97 & 0.46 \\
\hline Cadmium (total, mg/L) & ND & ND & ND & ND \\
\hline Chromium (total, mg/L) & ND & ND & ND & ND \\
\hline Lead (total, mg/L) & ND & ND & ND & ND \\
\hline Mercury (total, mg/L) & ND & ND & ND & ND \\
\hline Selenium (total, mg/L) & ND & ND & ND & ND \\
\hline Silver (total, mg/L) & ND & ND & ND & ND \\
\hline Iron (total, mg/L) & 13 & 0.6 & ND & ND \\
\hline Manganese (total, mg/L) & 1.4 & 0.17 & 0.057 & 0.01 \\
\hline Sodium (total, mg/L) & 8.6 & 140 & 38 & 15 \\
\hline Vanadium (total, mg/L) & ND & ND & ND & ND \\
\hline Benzene (mg/L) & ND & ND & ND & ND \\
\hline Toluene (mg/L) & ND & ND & ND & ND \\
\hline Ethylbenzene (mg/L) & ND & ND & ND & ND \\
\hline Total Xylenes (mg/L) & ND & ND & ND & ND \\
\hline Total Organic Halides (mg/L) & ND & ND & ND & ND \\
\hline Chloride (mg/L) & 19 & ND & ND & 43 \\
\hline Sulfate $(\mathrm{mg} / \mathrm{L})$ & 33 & 4.2 & 17 & 8 \\
\hline Nitrate Nitrogen (mg/L) & ND & 0.27 & ND & 0.48 \\
\hline Fluoride (mg/L) & 0.1 & 0.53 & 0.18 & 0.14 \\
\hline Total Recoverable Phenolics (mg/L) & ND & ND & ND & ND \\
\hline Cyanide (total, mg/L) & ND & ND & ND & ND \\
\hline Total Organic Carbon (mg/L) & 2.7 & 2.9 & 1.7 & 1.9 \\
\hline Naphthalene $(\mu \mathrm{g} / \mathrm{L})$ & ND & ND & ND & ND \\
\hline Other Semivolatiles & ND & ND & ND & ND \\
\hline
\end{tabular}

ND = not detected; s.u. = standard units. 
Table 23. NETL-MGN August 2001 Groundwater Data for "A Aquifer"

\begin{tabular}{|c|c|c|c|c|c|c|c|c|c|c|c|c|c|}
\hline \multirow{2}{*}{ Parameter } & \multicolumn{13}{|c|}{ Sample Location } \\
\hline & A & B & SP1A & SP4-A & SP8A & SP9A & I & $J$ & $\mathbf{K}$ & $\mathbf{L}$ & M & $\mathbf{N}$ & GAS-4 \\
\hline $\mathrm{pH}(\mathrm{s} . \mathrm{u})$ & 7.0 & 7.4 & 6.29 & 6.05 & 6.17 & 5.89 & 6.53 & 5.66 & 5.2 & 6.51 & 5.07 & 5.25 & 6.88 \\
\hline Specific Conductance ( $\mu$ mhos) & 863 & 310 & 285 & 281 & 396 & 790 & 335 & 651 & 1175 & 1608 & 368 & 657 & 1225 \\
\hline Temperature $\left({ }^{\circ} \mathrm{C}\right)$ & 16.4 & 16.9 & 15.6 & 16.7 & 16.4 & 15.8 & 20.6 & 20.2 & 22.1 & 19.3 & 21.2 & 20.3 & 19.6 \\
\hline Arsenic (total, mg/L) & ND & ND & ND & ND & ND & ND & 0.02 & ND & ND & ND & ND & ND & $\mathrm{ND}$ \\
\hline Barium (total, mg/L) & 0.38 & 0.28 & 0.15 & 0.046 & 0.36 & 0.18 & 1.3 & 0.2 & 0.11 & 0.065 & 0.048 & 0.11 & 0.12 \\
\hline Cadmium (total, mg/L) & $\mathrm{ND}$ & ND & $\mathrm{ND}$ & ND & ND & 0.0009 & $\mathrm{ND}$ & 0.0013 & 0.003 & 0.0022 & 0.0006 & 0.0013 & $\mathrm{ND}$ \\
\hline Chromium (total, mg/L) & ND & ND & ND & ND & ND & ND & $\mathrm{ND}$ & ND & ND & ND & ND & ND & ND \\
\hline Lead (total, mg/L) & ND & ND & ND & ND & ND & ND & ND & ND & ND & ND & ND & ND & ND \\
\hline Mercury (total, mg/L) & ND & ND & ND & ND & ND & ND & ND & ND & ND & ND & ND & ND & ND \\
\hline Selenium (total, mg/L) & ND & ND & ND & ND & ND & ND & ND & ND & ND & 0.0078 & ND & ND & ND \\
\hline Silver (total, mg/L) & ND & ND & ND & ND & ND & ND & ND & ND & ND & $\mathrm{ND}$ & ND & ND & ND \\
\hline Iron (total, mg/L) & 19 & 36 & 42 & 1.4 & 42 & ND & 72 & 0.96 & ND & 0.96 & 3.3 & 0.36 & 1.6 \\
\hline Manganese (total, mg/L) & 1 & 1.4 & 1.7 & 0.28 & 2.7 & 2.7 & 0.46 & 0.12 & 2 & $\mathrm{ND}$ & 1.4 & 0.48 & 6.9 \\
\hline Sodium (total, mg/L) & 6.9 & 5.8 & 14 & 9.2 & 8 & 200 & 17 & 62 & 1500 & 270 & 27 & 65 & 84 \\
\hline Vanadium (total, mg/L) & ND & ND & ND & ND & ND & ND & ND & ND & ND & ND & ND & ND & ND \\
\hline Benzene (mg/L) & ND & ND & ND & ND & ND & ND & ND & ND & ND & ND & ND & ND & ND \\
\hline Toluene (mg/L) & ND & ND & ND & ND & ND & ND & ND & ND & ND & ND & ND & ND & ND \\
\hline Ethylbenzene (mg/L) & ND & ND & ND & ND & ND & ND & ND & ND & ND & ND & ND & ND & ND \\
\hline Total Xylenes (mg/L) & ND & ND & ND & ND & ND & ND & ND & ND & ND & ND & ND & ND & ND \\
\hline Total Organic Halides (mg/L) & ND & ND & ND & ND & ND & ND & ND & ND & ND & ND & ND & ND & ND \\
\hline Chloride (mg/L) & ND & ND & 5.2 & 26 & 44 & 470 & 28 & 170 & 350 & 530 & 38 & 170 & 210 \\
\hline Sulfate $(\mathrm{mg} / \mathrm{L})$ & 16 & 29 & 50 & 24 & 24 & 70 & 31 & 51 & 61 & 160 & 94 & 64 & 69 \\
\hline Nitrate Nitrogen (mg/L) & ND & ND & ND & ND & ND & 0.75 & ND & 0.68 & 1.6 & 1.2 & 0.18 & 0.6 & 0.14 \\
\hline Fluoride $(\mathrm{mg} / \mathrm{L})$ & 0.098 & 0.069 & 0.055 & 0.11 & 0.072 & 0.056 & 0.064 & 0.065 & 0.48 & 0.34 & 0.21 & 0.094 & 0.13 \\
\hline Total Recoverable Phenolics (mg/L) & 0.007 & ND & ND & 0.0056 & 0.0056 & 0.0087 & ND & 0.0076 & ND & ND & ND & ND & 0.0052 \\
\hline Cyanide (total, mg/L) & ND & ND & ND & ND & ND & ND & ND & ND & ND & ND & ND & ND & ND \\
\hline Total Organic Carbon (mg/L) & 3.0 & 2.8 & 3.0 & 1.9 & 4.0 & 2.2 & 4.0 & 2.0 & 2.4 & 4.7 & 2.7 & 2.6 & 6.5 \\
\hline Naphthalene $(\mu \mathrm{g} / \mathrm{L})$ & ND & ND & ND & ND & ND & ND & ND & ND & ND & ND & ND & ND & ND \\
\hline Other Semivolatiles & ND & ND & ND & ND & ND & ND & $\mathrm{ND}$ & ND & ND & ND & ND & ND & ND \\
\hline
\end{tabular}


$\mathrm{ND}=$ not detected; $\mathbf{s} . \mathrm{u} .=$ standard units 
Table 24. NETL-MGN August 2001 Groundwater Data for "B-C Aquifer"

\begin{tabular}{|c|c|c|c|c|c|}
\hline \multirow{2}{*}{ Parameter } & \multicolumn{5}{|c|}{ Sample Location } \\
\hline & 11 & SP2-BC & $32 \mathrm{~A}$ & 31 & GAS-5 \\
\hline $\mathrm{pH}(\mathrm{s} . \mathrm{u})$ & 6.91 & 6.59 & 5.31 & 6.12 & 6.52 \\
\hline Specific Conductance ( $\mu$ mhos) & 1179 & 470 & 1457 & 693 & 885 \\
\hline Temperature $\left({ }^{\circ} \mathrm{C}\right)$ & 16.9 & 15.6 & 20.7 & 19.7 & 18.3 \\
\hline Arsenic (total, mg/L) & ND & ND & ND & ND & ND \\
\hline Barium (total, mg/L) & 0.25 & 0.03 & 0.063 & 0.12 & 0.18 \\
\hline Cadmium (total, mg/L) & ND & ND & 0.002 & ND & ND \\
\hline Chromium (total, mg/L) & ND & ND & ND & ND & ND \\
\hline Lead (total, mg/L) & ND & ND & ND & ND & ND \\
\hline Mercury (total, mg/L) & ND & ND & ND & ND & ND \\
\hline Selenium (total, mg/L) & ND & ND & ND & ND & ND \\
\hline Silver (total, mg/L) & ND & ND & ND & ND & ND \\
\hline Iron (total, mg/L) & 32 & ND & ND & 1.6 & 2 \\
\hline Manganese (total, mg/L) & 1.6 & 0.048 & 2.5 & 7 & 8.2 \\
\hline Sodium (total, mg/L) & 5.8 & 4.8 & 230 & 84 & 61 \\
\hline Vanadium (total, mg/L) & ND & ND & ND & ND & ND \\
\hline Benzene (mg/L) & ND & ND & ND & ND & ND \\
\hline Toluene (mg/L) & ND & ND & ND & ND & ND \\
\hline Ethylbenzene (mg/L) & ND & ND & ND & ND & ND \\
\hline Total Xylenes (mg/L) & ND & ND & ND & ND & ND \\
\hline Total Organic Halides (mg/L) & ND & ND & ND & ND & ND \\
\hline Chloride (mg/L) & 5.2 & 7.8 & 450 & 180 & 130 \\
\hline Sulfate $(\mathrm{mg} / \mathrm{L})$ & 24 & 16 & 96 & 45 & 73 \\
\hline Nitrate Nitrogen (mg/L) & ND & 0.62 & 0.95 & 0.077 & ND \\
\hline Fluoride (mg/L) & 0.077 & 0.12 & 0.25 & 0.074 & 0.13 \\
\hline Total Recoverable Phenolics (mg/L) & ND & ND & 0.006 & ND & ND \\
\hline Cyanide (total, mg/L) & ND & ND & ND & ND & ND \\
\hline Total Organic Carbon (mg/L) & 3.7 & 5.2 & 2.9 & 3.2 & 5.0 \\
\hline Naphthalene $(\mu \mathrm{g} / \mathrm{L})$ & ND & ND & ND & ND & ND \\
\hline Other Semivolatiles & ND & ND & ND & ND & ND \\
\hline
\end{tabular}

ND = not detected; s.u. = standard units. 